UNIVERSITY OF CALIFORNIA

COLLEGE OF AGRICULTURE

AGRICULTURAL EXPERIMENT STATION

BERKELEY, CALIFORNIA

\title{
THE UTILIZATION OF
}

\section{EL DORADO COUNTY LAND}

DAVID WEEKS, A. E. WIESLANDER, and C. L. HILL

Results of a coöperative investigation conducted by the California Forest and Range Experiment Station of the United States Forest

Service, United States Department of Agriculture, and the

California Agricultural Experiment Station

\section{BULLETIN 572}

May, 1934

CONTRIBUTION FROM THE

GIANNINI FOUNDATION OF AGRICULTURAL ECONOMICS 


\section{CONTENTS}

Introduction . .

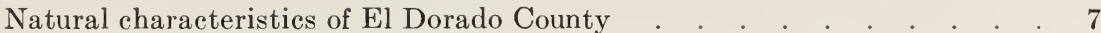

Character of the land . . . . . . . . . . . . 7

The forest and other vegetative cover . . . . . . . . . . . . . . . . . 13

The utilization of El Dorado County lands for agriculture . . . . . . 21

Orchard crops . . . . . . . . . . . . . . . . . . 22

Irrigation . . . . . . . . . . . . . . . 30

General characteristies of the livestock industries .

Costs and returns from livestock farming . . . . . . . . . . . . . 40

Forest-crop possibilities . . . . . . . . . . . . . . 49

Productivity of forest lands in eastern El Dorado County . . . . . . . . 50

Productivity of forest lands in western El Dorado County . . . . . . . 51

Relation of the manufacturing industries to land utilization . . . . . . . 56

The lumbering industries . . . . . . . . . . . . . . . . . . . . 56

Hydroelectric power . . . . . . . . . . . . . . . . . 60

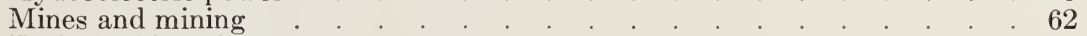

Fruit-packing plants . . . . . . . . . . . . . . . . . . 63

Recreation and its relation to land use $\quad . \quad$. . . . . . . . . . . . . . 64

Camping and summer homes . . . . . . . . . . . . . . . . 64

County expenditures for roads and schools as affected by land utilization . 68

Cost of education . . . . . . . . . . . . . 68

Road costs . . . . . . . . . . . . . . . . . . . . . 71

What land-use planning involves . . . . . . . . . . . . . . 72

An agricultural-development policy . . . . . . . . . . . . . 73

Abandonment of farming on an unproductive frontier . . . . . . . . $\quad 76$

Utilization of wild lands . . . . . . . . . . . . . . . . . . 77

Reorganization of the livestock industries . . . . . . . . . . . . . . 79

A program of local industrial development . . . . . . . . . . . . . $\quad$. 85

The many uses of land and their relation to each other $\quad$. . . . . . . . . 86

General economic classification of El Dorado County lands and suggested

programs of utilization
Area I, fruit production supplemented by forest crop and manufacturing industry

Area II, potential farm and/or forest crop . . . . . . . . . 96

Area III, livestock production _. . . . . . . . . . . . . . . . . . 98

Area IV, forest crop with recreation and grazing . . . . . . . . . . . . 101

Area V, recreation with forest crop and grazing . . . . . . . . . . . 104

The means by which land utilization may be improved _ . . . . . . 104

A proposed initial step . . . . . . . . . . . . . . . . . 114

Acknowledgments . . . . . . . . . . . . . . . . . . . . 115 


\section{THE UTILIZATION OF EL DORADO COUNTY LAND ${ }^{1,2}$}

DAVID WEEKS, ${ }^{3}$ A. E. WIESLANDER, ${ }^{4}$ AND C. L. HILL ${ }^{5}$

\section{INTRODUCTION}

This BULLETin is a report of the results of the first large-scale study, in California, of land utilization and of the complex problems arising out of its relations to the economic and social structure. Perhaps in no other area of California are the conflicts between major uses of nonurban land more critical than in the foothill zone on the eastern side of the Great Valley, extending from the mouth of the Sacramento Canyon at Kennett, in a southeasterly direction for roughly 500 miles, nearly to the southern end of the Sierra Nevada. Of this region El Dorado County constitutes one of the most typical portions, having many advantages for a first effort in land-use planning.

The investigations here reported were made as the initial step in the search for a solution of the land-use problems of California, and not of El Dorado County alone. The point of view is not so much that of sitting in judgment upon the rival claims of conflicting land uses as of attempting, on the basis of land suitability, a conscious coördination of the major uses of the area, namely, agriculture, grazing, forestry and recreation, and numerous minor uses, such that land use will make its full contribution towards the most serviceable and harmoniously functioning economic and social organization possible, under the conditions of each case.

El Dorado County extends in approximately an east and west direction from the agricultural plains of the Sacramento Valley across the intermediate foothills and the higher nonagricultural mountain lands of the Sierra Nevada to the intermountain plateau, at the bend in the eastern boundary of California. It constitutes a typical cross section of that portion of the range. Its general situation is shown in figure 1 .

1 Received for publication October 18, 1933.

2 Paper No. 53, The Giannini Foundation of Agricultural Economics.

3 Associate Professor of Agricultural Economies, Associate Agricultural Economist in the Experiment Station, and Associate Agricultural Economist on the Giannini Foundation.

4 Associate Silviculturist in the California Forest and Range Experiment Station, Forest Service, United States Department of Agriculture.

5 Senior Forester in charge of Forest Products, in the California Forest and Range Experiment Station, Forest Service, United States Department of Agriculture. 
The forests, certain minerals, recreational opportunities, water power, grazing land, and a limited amount of agricultural crop land represent the more important resources.

This area has contributed to other counties and states a large proportion of the great wealth derived from gold mines, forests, and orchards. Because of the nature of these resources and the character of their exploitation there has resulted less benefit than should have accrued to the localities from which they were derived. The resources which yet remain are great, but careful husbanding will be required lest this county might become impoverished and thus lose a great heritage.

Land-Utilization Problems of the Foothill Areas.-Economic problems characteristic of much of the Sierra Nevada foothill area are given striking emphasis in El Dorado County. The population, once the largest of any county in the state, is sparse and in many sections has been declining. Declining populations have been followed by declining school attendance. Scattered farms, an exceedingly small proportion of the total area under cultivation, and the frequent inability of agricultural enterprises to support themselves without supplementary sources of income give rise to financial difficulties both private and public. Throughout rather extensive areas, enst of government exceeds public income from county sources, while a large proportion of public funds expended are drawn from more densely populated sections of the county. These conditions are similar to those prevailing in other regions of the United States, especially in extensive areas in the Appalachian Mountain region and in the states bordering the Great Lakes.

There are some problems, however, which are more or less peculiar to the western slopes of the Sierra Nevada and which are common to a long tier of California foothill counties. In the lower areas forest and agriculture compete for the same land. The mountainous portions of these counties are timber and grazing areas, the use of which, for the latter purpose, in conjunction with the grass and crop lands of the foothills and valleys, has not been developed to the full extent of its possibilities. A complex livestock industry requiring supplementary crop feeds and range lands forces a consideration of the interdependence of the lands in different situations. The higher elevations are becoming a mecea of summer recreation and winter sports through which a new land use has been developing. Here recreational and grazing uses may come into conflict. California agriculture and industry depend to a great extent upon water supplies which have their sources in the mountains and foothills of these counties. Soil and water conservation, therefore, demand serious consideration. Farms adjacent to forest areas are subject to crop and livestock losses from deer and other wild animals. 
On the other hand, wild animals are making a losing struggle against the encroachments of civilization upon the wilderness.

Irrigation of a portion of the area has resulted in a wide variation in types of farming and has introduced financial and economic questions

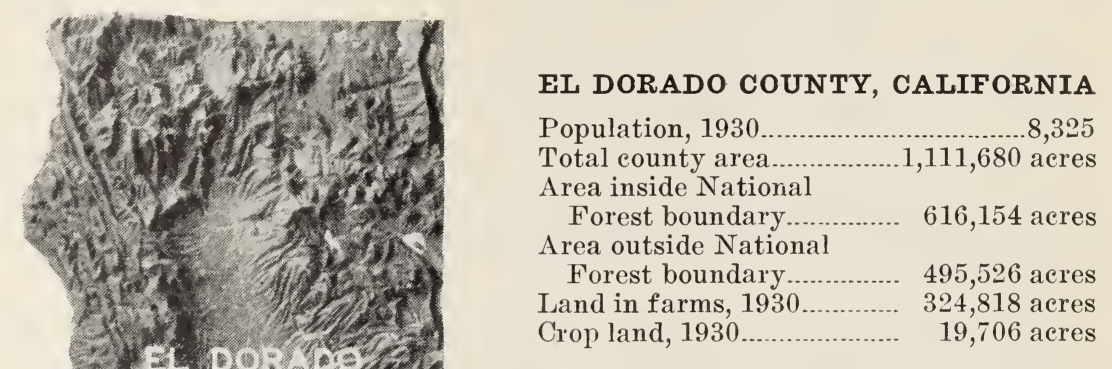

Fig. 1.-El Dorado County extends in approximately an east and west direction from the plains of the Sacramento Valley across the Sierra Nevada to the intermountain plateau, and constitutes a typical cross section of that range at the bend in the eastern border of California. (Copyright by H. A. Sedelmeyer.)

peculiar to agriculture under irrigation. Although large land holdings are frequent, a multitude of small land holdings, some of them too small for economical use, are consequent upon haphazard land settlement, mining activity, and a somewhat intricate industrial situation. A few of the industries are decadent because of the depletion of resources upon which they depend or because of changes in demand. 
Fires intermittently sweep across the grass, brush, and timber lands, causing great destruction to property, denuding the hillsides and subjecting them to serious erosion. In many cases soil depletion by erosion has resulted from fires removing the protective cover or from the extension of agricultural cultivation too far up the steeper slopes.

These are some of the land-utilization problems of the foothill areas. Their consideration in more detail for El Dorado County will have significance over a much wider area than that for which they are here specifically considered. The solution of these specific problems constitutes the major objective in planning the utilization of the lands of the county.

Different Interests Involved in Land Utilization.-In planning land utilization it becomes necessary to set some goal that it is desirable to attain. If such a goal is to be defined it must be considered in the light of the many interests involved. These interests range all the way from those of the local landowner who is desirous of receiving a maximum income from the land which he owns to the interests of the distant populations who enjoy the fruits of the land and the landowner's labors. There are also those who are concerned with the liabilities of the county as well as with the assets represented by the productivity of the natural resources. The taxpayers of California are affected in a very direct way by the public costs as well as by the returns to the public resulting from the manner of using the land.

In planning the use of land, therefore, it is necessary to keep in mind the different points of view represented by the landowners, the resident farmers, the local business and industrial organizations, the holders of bonds and mortgages secured by local properties, the taxpayers of the county and state, the users of water having its source in El Dorado County, and the motoring, fishing, hunting, and recreation-seeking public. If it can be denied that the lovers of beauty have a real vested interest in the esthetic values of the forested hillsides, estimates of material economic values of future lumber supplies are sufficiently great to convince the more sober-minded citizen that there is a public interest in the maintenance and protection of the forests.

Not only is it important to consider these different interests as they may be interpreted in terms of the demands of today, but also the needs and desires of future generations should be taken into consideration in the community's planning. This is particularly important with respect to those resources which require many decades to restore once they have been depleted.

The Aim in Land-Use Planning.-An attempt has been made to coördinate the many different uses of land towards the best total pros- 
perity of the community, as far as possible, in harmony with the varied local, state, and national interests. At this point the objectives can be stated only in very general terms. In a later section of this bulletin, after the reader has become more familiar with the land character and land utilization in the county, he will find a more detailed statement of the factors involved in land-use planning. The general objectives assumed by the writers of this bulletin are to coördinate and harmonize land uses so as:

1. To obtain for the owners of the land and for the community and the local government the greatest possible return in proportion to the amount of energy and capital applied.

2. To protect farmers from the results of unwise expansion and to give such assistance as may be possible in the efforts being made throughout the country to balance production and consumption.

3. To assist residents in the area to adjust their economic programs to changing conditions.

4. To conserve for the general public of this and future generations the natural resources, including the soil and its fertility. In the maintenance of these resources in unimpaired productivity the public has an interest superior to that of private exploitation.

5. To provide information concerning adaptations and probable future utilization of lands which will make possible progressively greater efficiency both in land use and in the administration and financing of the several functions of government and public-service agencies.

Before discussing the means by which these objectives may be reached it is important to consider in more detail the natural character of El Dorado County lands and the manner in which they have been used.

\section{NATURAL CHARACTERISTICS OF EL DORADO COUNTY}

\section{CHARACTER OF THE LAND}

The relief of the lands of the county has been determined to a great extent by the tributaries of the American and Cosumnes rivers whose deep canyons divide the western slope of the Sierra Nevada into long, parallel, major ridges falling westward to the foothills of western El Dorado County. Upon the gravelly stream banks prospectors can still be seen with their gold pans in search of some of the remaining treasure left behind by pioneers of the gold-rush period. In the eastern mountainous area the ridges that separate the canyons are largely clothed with timber which is of excellent quality. At the lower elevations the early miners removed most of the timber, and in the place of part of it their 


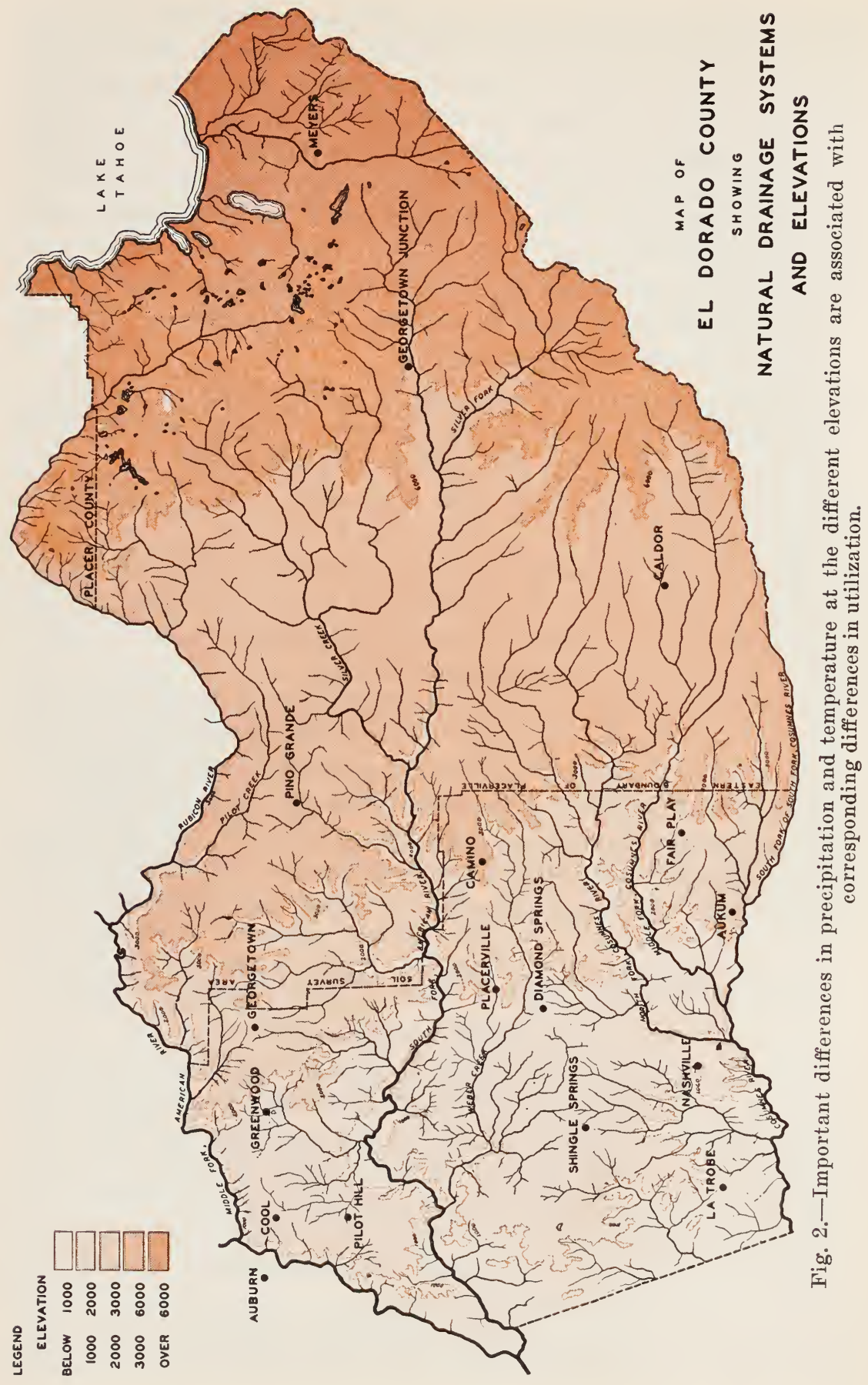


successors have planted orchards or grazed livestock, while part of the land has grown back to second-growth timber.

The locations and character of the orchards and other agriculture have been determined by the quantity, quality, and location of the different soil types, the natural vegetation, the irrigation water supply and the position of the old mining ditches later used as irrigation canals, the locations of the towns which are related to the early mining activities, the extent to which the tributary streams have cut into the land surface, the degree of isolation, resulting from the river gorges, and, by no means of least importance, elevation. Elevations are shown on a map of the county (fig. 2) which also shows the natural drainage systems. The upper limit of the Placerville soil-survey area, comprising about 345,000 acres in the western part of the county, is shown on this map. The other boundaries of this soil-survey area coincide with the rivers forming the county lines.

Soil Classification.-The Division of Soil Technology of the University of California has differentiated the soils of the Placerville soil-survey area ${ }^{6}$ into 27 different kinds of soil. With their coöperation these soils have been combined into 8 divisions, and these divisions in turn have been combined into 3 major classes as follows :

\section{Eu. Dorado Soll Classification}

Class A $\begin{cases}\text { Division I } & \begin{array}{r}\text { - Deep residual soils of medium to heavy texture with } \\ \text { heavy-textured subsoils, largely the deep red clay of } \\ \text { the Aiken series. }\end{array} \\ \text { Division II } & \begin{array}{l}\text { - Deep residual soils of light texture, granitic in charac- } \\ \text { ter, of low water-holding capacity but productive under } \\ \text { irrigation. }\end{array}\end{cases}$

Class B $\begin{cases}\text { Division III } & \begin{array}{l}\text { - Shallow residual soils. For the most part these are the } \\ \text { clay loams of the Aiken series. } \\ \text { Division IV }\end{array} \\ \text { - } & \text { Stony residual soils. } \\ \text { Division V } & \text { Shallow, heavy-textured soil composed entirely of } \\ & \text { Sierra clay loam, a red heavy-textured soil from } 2 \text { to } \\ & 21 / 2 \text { feet deep. }\end{cases}$ Class C $\left\{\begin{array}{l}\text { Division VI - Stony shallow soils. } \\ \text { Division VII - Rough mountainous land-soil types not differentiated. } \\ \text { Division VIII - -Serpentine ridges and placer diggings and tailings. }\end{array}\right.$

Of the total area classified, class A soils comprise 32 per cent, class B soils 29 per cent, and class $\mathrm{C}$ soils 39 per cent. In ordinary parlance, these 3 classes of soil might be called good, medium, and poor with reference to agricultural crop production. Before discussing the relative

6 Storie, R. Earl, and D. F. Trussell. Soil Survey of the Placerville area, California. U. S. Dept. Agr. Bur. Chem. and Soils Series 1927(34) :1-35, 1927. 
quality of these different soil classes, however, it will be well to consider some of the other factors which affect productivity and utilization.

Land Classification on the Basis of Soil and Other Factors.-For the purpose of securing a land classification giving weight to topography and climatic conditions along with soil quality, class A and class B soils were each separated into two subclasses based upon the roughness ${ }^{7}$ of the land and its elevation, which resulted in the following general classification of land:

Class 1 land includes all lands having gently rolling topography and class A soils at elevations up to 3,500 feet and all lands having rolling topography and class A soils up to 2,000 feet elevation.

Class 2 land includes all lands having rolling topography and class A soils between elevations of 2,000 feet and 3,500 feet.

Class 3 land includes all lands having gently rolling topography and class B soils below 2,000 feet elevation.

Class 4 land includes lands having gently rolling topography and class $\mathrm{B}$ soils above 2,000 feet in elevation and lands having rolling topography and class $B$ soils situated at elevations up to 3,500 feet.

Class 5 land includes all lands above an elevation of 3,500 feet and lands having class $\mathrm{C}$ soils below that elevation.

The Placerville soil-survey area comprises 72 per cent of the lands of the county lying below the Eldorado National Forest. One-fifth of the lands of this soil area are class 1 lands.

Climate.-The above land classification based upon soils, roughness, and elevation is consistent also with climatic differences because of the general relation which is found between climatic conditions and elevation.

In general, precipitation increases with altitude in the Sierras, but the degree of this influence of altitude varies in the different parts of the state. Within the limits of western El Dorado County and immediately adjacent areas, in going from an altitude of 1,000 feet to one of 3,000 feet, one encounters an increase of 24 inches in annual precipitation, a reduction of $6^{\circ}$ Fahrenheit in mean temperature, and a frostfree period 68 days shorter. Killing frosts occur on the average a month and a half later in the spring at an elevation of 3,000 feet than they do at 1,000 feet, while the total heat available for plant growth is approximately 73 per cent of that available at the lower elevation. Table 1

7 The topography of the lands of western El Dorado County was classified on the basis of the number of times the perimeter of a quarter section of land was crossed by contours on a topographic map, the contour interval of which was 100 feet. On land having gently rolling topography this index of roughness was from 4 to 10, on rolling land it was 11 to 20, and on rough land it was over 20 . 
gives the more important facts concerning El Dorado County climatic conditions.

Actual experiences of farmers have been depended upon primarily, however, in estimating the relation of climatic influences to crop production and prices, supplemented by more detailed climatic records. The importance of these climatic differences will be observed in later sections.

TABLE 1

Approximate Climatic Conditions Prevailing at Different Elevations in El Dorado County

\begin{tabular}{|c|c|c|c|c|c|c|}
\hline \multirow[b]{2}{*}{ Elevation } & \multicolumn{4}{|c|}{ Estimated temperature conditions } & \multicolumn{2}{|c|}{ Estimated precipitation } \\
\hline & $\begin{array}{c}\text { Mean } \\
\text { annual } \\
\text { temperature }\end{array}$ & $\begin{array}{l}\text { Average } \\
\text { frost-free } \\
\text { period }\end{array}$ & $\begin{array}{l}\text { Relative } \\
\text { amount } \\
\text { of heat* }\end{array}$ & $\begin{array}{l}\text { Date of last } \\
\text { killing frost } \\
\text { in spring }\end{array}$ & $\begin{array}{l}\text { Average } \\
\text { annual }\end{array}$ & $\begin{array}{l}\text { Per cent dur- } \\
\text { ing frost-free } \\
\text { period }\end{array}$ \\
\hline feet & $\begin{array}{c}\text { degrees } \\
\text { Fahrenheit }\end{array}$ & days & per cent & & inches & per cent \\
\hline 500 & 62 & 283 & 100 & March 7 & 24 & 43 \\
\hline 1,000 & 60 & 265 & 94 & March 19 & 30 & 32 \\
\hline 1,500 & 58 & 247 & 88 & March 31 & 36 & 26 \\
\hline 2,000 & 57 & 230 & 82 & April 12 & 42 & 22 \\
\hline 2,500 & 55 & 213 & 76 & April 23 & 48 & 19 \\
\hline 3,000 & 54 & 197 & 69 & May 5 & 55 & 15 \\
\hline 3,500 & 52 & 180 & 63 & May 17 & 60 & 14 \\
\hline 4,000 & 51 & 164 & 57 & May 28 & 68 & 12 \\
\hline
\end{tabular}

* The heat available for plant growth is derived from the temperatures exceeding $34^{\circ}$ Fahrenheit during the growing season.

Sources of data:

The items in this table have been estimated from correlations based upon United States Department of Agriculture Weather Bureau data, U. S. Geological Survey quadrangles, and observations made by the authors.

Resultant Physical Character of Land Areas.-Combinations of different classes of land and their relative proportions in an area determine the physical character of the area. Thus, the extreme southwestern portion of the county can be described in terms of its gently rolling topography, its extensive areas of shallow residual soils, differing from each other primarily in the degree of stoniness, and its low elevation. Above the lands of this character the topography becomes more rugged, a larger number of small bodies of soils of different classifications are found intermingled, while the rise in elevation is accompanied by a shorter and cooler frost-free period and a slightly heavier precipitation. Eastward from these lands is another extensive tract of land of rolling topography but having practically no deep soils, while the frost-free period is still shorter and of lower temperature than is the case with the lands to the west. Between this area and the National Forest boundary is a series of ridges and canyons. The ridges are composed of extensive areas of deep residual soils; the canyons that separate them are 
rugged, rocky gorges, and increasing altitude results in a shorter growing season and a declining amount of heat available for plant growth.

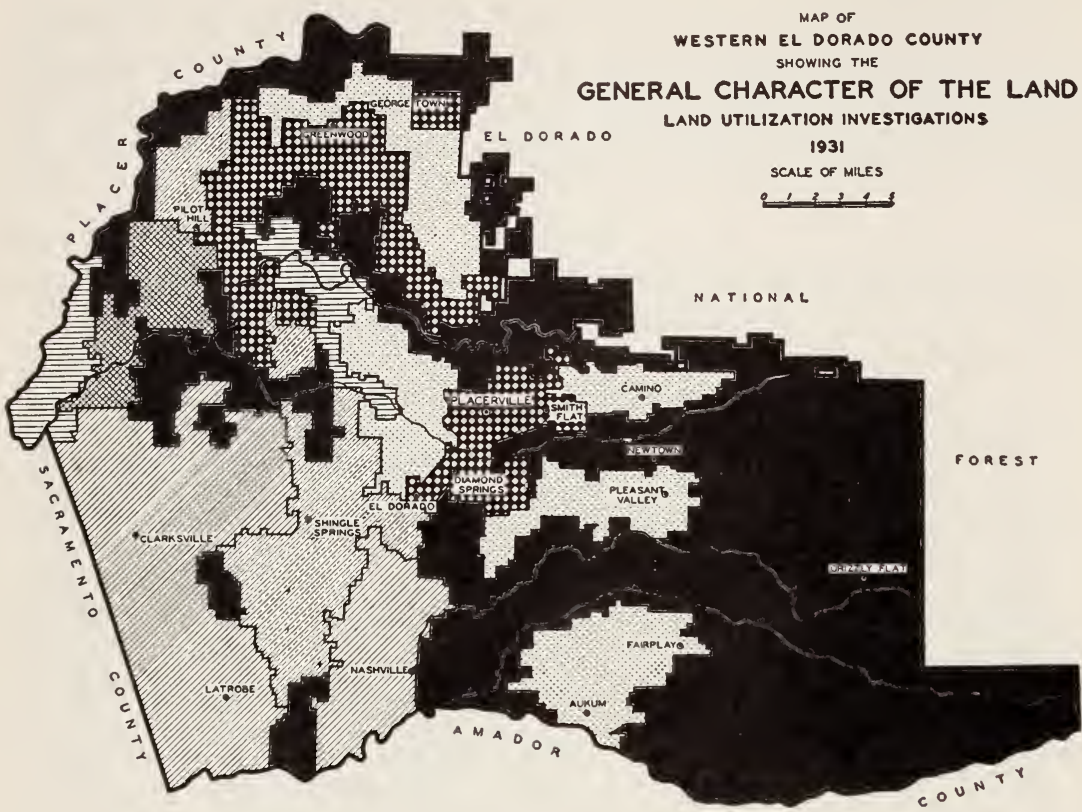

\section{LEGEND}

LAND HAVING A PREDOMINATING PROPORTION OF DEEP RESIDUAL SOILS OF BOTH LIGHT AND HEAVY TEXTURES, AND HAVING GENTLY ROLLING TO ROLLING TOPOGRAPHY. ELEVATIONS RANGE FROM ISOO TO 3500 FEET.

LAND HAVING DEEP LIGHT TEXTURED RESIDUAL SOILS, AND GENTLY ROLLING TOPOGRAPHY, IN COMBINATION WITH A ROUGHLY EQUAL AMOUNT OF LAND HAVING ROLLING TO MOUNTAINOUS TOPOGRAPHY. ELEVATIONS RANGE FROM 200 TO 1500 FEET.

PAND HAVING A LARGE PERCENTAGE OF SHALLOW SOILS AND ROLLING TOPOGRAPHY, IN COMBINATION WITH SMALLER AMOUNTS OF LAND HAVING DEEP SOIL AND GENTLY ROLLING TOPOGRAPHY. ELEVATION RANGES FROM 500 TO 2000 FEET BUT FOR MOST OF THE AREA IS BETWEEN 1000 AND ISOO FEET.

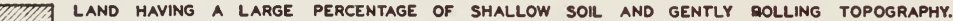
ELEVATION RANGES FROM 500 TO 2000 BUT FOR THE MOST PART IS LESS THAN IOOO FEET.

LAND A LARGE PROPORTION OF WHICH IS ROLLING AND MOUNTAINOUS. SHALLOW SOILS PREDOMINATE. ELEVATION, 500 TO 1500 FEET.

B:8: SMALLER PROPORTIONS OF ROUGH AND ROCKY LAND. ELEVATION 1500 TO 2000 FEET.

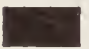
MAINLY ROUGH, MOUNTAINOUS, OR ROCKY LAND, INCLUDING A FEW ISOLATEd TRACTS OT HIGH
PLAINS. WIDE RANGE OF ELEVATION.

Fig. 3.- The general character of the land in any area is the result of temperature, precipitation, soils, topography, and especially the arrangement and proportions in which lands having differences in these physical characteristics are combined.

North of the South Fork of the American River in all of these areas the topography, in general, is rougher, the variability in soils is greater, and isolation resulting from the deep river canyons is greater than it is 
south of that river. The geographical position of these different areas, together with a summary description showing the more important differences in the physical character of the land, is presented in figure 3.

The economic significance of these differences in land character will be observed as the various phases of land utilization are related to them.

\section{THE FOREST AND OTHER VEGETATIVE COVER}

A clear idea of the natural vegetation of El Dorado County, its distribution, past and present, and the causes which have produced changes in it, is necessary for intelligent appraisal of possible alternative uses of $\mathrm{El}$ Dorado County lands. For this purpose, also, there must be taken into account the mountain and forest section of the county as well as the agricultural section.

Information pertaining to the forest cover of eastern El Dorado County, which lies almost wholly within and above the western boundary of the Eldorado National Forest, was available for this study in United States Forest Service records. For the western part of the county, outside of and below the National Forest boundary, a detailed field survey was necessary.

Eastern El Dorado County Forests.-The eastern, or mountainous, portion of the county may conveniently be discussed first. It embraces an area of 631,361 acres, or about 57 per cent of the county total. It all lies above the altitudinal limits of general agriculture. On the western side of the Sierra summit, below 6,000 feet in elevation, much of the land produces excellent saw-timber stands of pure pine or pine and fir mixed. In fact some of the finest stands of sugar pine in California are located here. On both sides of the summit, between 6,000 and 7,000 feet elevation, are lands bearing good stands of fir, both white and red, and Jeffrey pine. At still higher elevations these stands give way to scrub alpine timber or bare rock, which flank the summits on either side in a band of varying width.

There is a total area of commercial virgin saw timber of about 375,000 acres, including some 38,500 acres of virgin timber still remaining just west of the National Forest boundary and really belonging with the main timber body. These lands support a total stand of nearly 8 billion feet, board measure, of which about 45 per cent consists of the valuable ponderosa pine (formerly called western yellow pine) and sugar pine, about 40 per cent of white and red fir, which are of potential pulpwood value rather than for saw timber, and the remainder of Douglas fir and incense cedar. This timber, both by acreage and amount, is about equally divided between government and private ownership. The private tim- 
ber is the more valuable, however, being more accessibly located and containing a larger proportion of pine.

The Original Vegetative Cover in Western El Dorado County.-The survey of the vegetation of the western, or foothill, section of the county not only provided information about the present vegetative cover, but

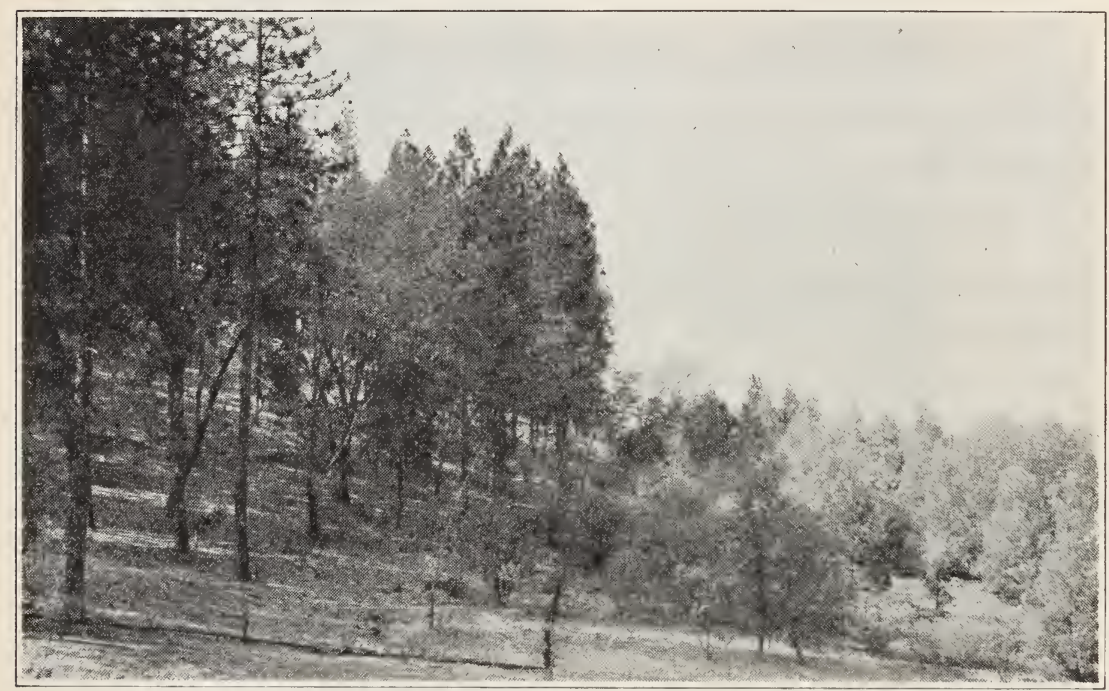

Fig. 4.-This straight-line fence boundary between the second-growth ponderosa pine and the Digger pine and oak woodland in the vicinity of Aukum shows that the woodland is not natural. The valley oak, interior live oak, and Digger pine found here do not oceur with ponderosa pine in nature but invade land from which it has been cleared either by the axe or byofire.

also disclosed that it is markedly different in character from that originally found by the miners of the gold-rush days.

It seems apparent that the virgin coniferous forest formerly extended down to as low as 1,000 feet in elevation, occupying the area shown on the map of figure 13 as now restocked cut-over land or deforested land. Although the deforested area was determined in this survey as capable of growing timber by the character of its soil coupled with growth measurements of scattered individuals and groups of second-growth pine, it is probable that some portions of this area at least had already been deforested by fire prior to the advent of the miner. It is also probable that some areas were once forested that now do not show any evidence of timber-growing capacity and therefore have not been mapped as deforested.

In addition to the occurrence of scattered pine remnants which furnished the basic information for ascertaining timber-growing capaci- 
ties, other interesting evidences of former forests were found. One of these was the presence of the California black oak, which invariably grows with ponderosa pine at its lower limits, and survives by sprouting when the conifer succumbs to the axe and fire. Several instances similar to that illustrated in figure 4 were found where the boundary lines between forest and nonforest cover coincide with property line fences. The cemetery of El Dorado, as shown in figure 5, as well as that of Frenchtown, has preserved excellent stands of the second-growth pine

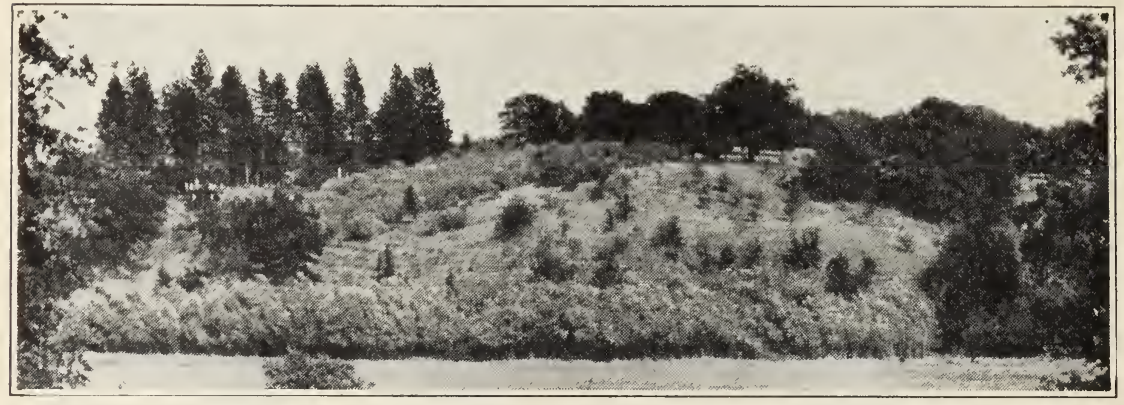

Fig. 5.-This sixty-year-old second-growth stand of ponderosa pine preserved in the cemetery of El Dorado (the "Mud Springs" of early mining days) is evidence of former forest in this locality from which it has now otherwise disappeared.

which were destroyed outside of them. Such names on the map of the county as Sawmill Creek, Sawmill Ravine, and Shingle Springs, as well as known locations of early-day sawmills, including the famous Sutter Mill at Coloma, indicate former lumbering activities within the now deforested areas.

Below the timber belt there were grasslands, first a belt mainly of grassy woodland, and below that the grassland proper. The occurrence in El Dorado County of established chamise seedlings in grasslands bordering burned-over chaparral areas indicates that brush fields are extended as a result of fire at the expense of grass, and that probably the original grassland area was greater in extent than that oceupying nonforest land today. This natural range land then supported native grasses, probably largely perennial and of considerable forage value. The present vegetation consists largely of introduced annual grasses and weeds many of which are either obnoxious or of low forage value. Some idea of what the original cover may have consisted of is brought to light by remnant areas that have escaped the deteriorating effects of overgrazing and repeated fires. Recent field studies by the United States Forest Service in foothill areas similar to those in El Dorado County have disclosed a number of small protected areas on which native peren- 
nial grasses still comprise most of the vegetation. On adjoining depleted ranges, in contrast, just as in El Dorado County, introduced annual grasses and weeds have largely replaced the native perennial grasses. The evidence seems to show that these changes not only have been coincident with, but have resulted from, the occupation of the land by white men.

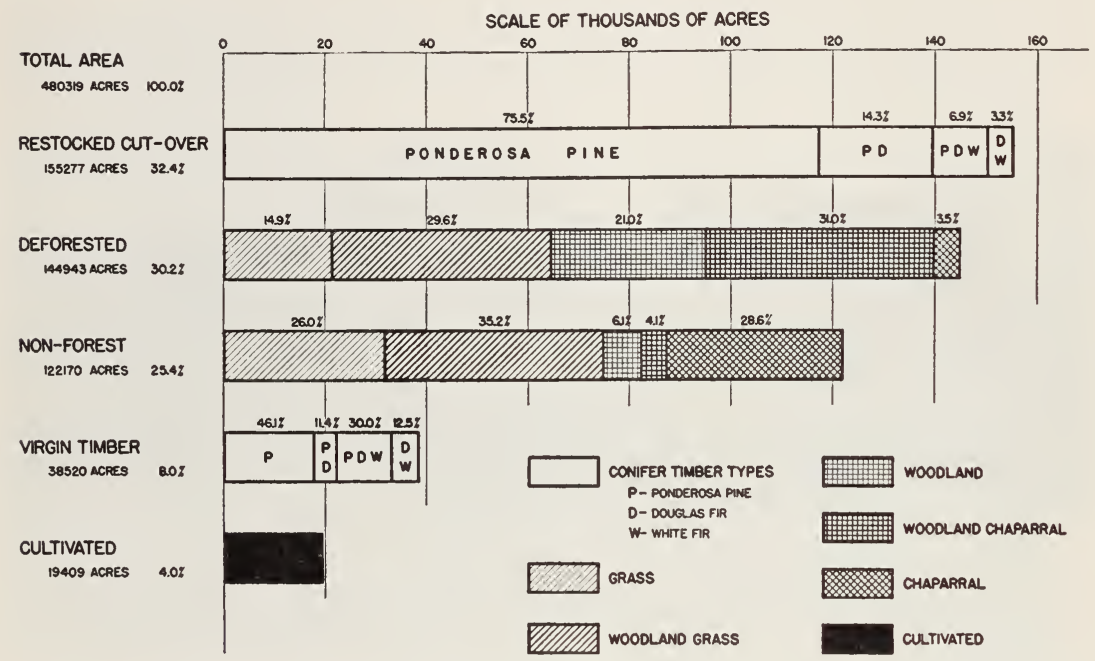

Fig. 6.-Vegetative cover classification of western El Dorado County lands. Cutover lands are designated as restocked when more than 10 per cent of the ground space is now occupied by regrowth of the commercial timber trees. When 10 per cent or less of the cut-over or other previously forested areas are so occupied the lands are classified as deforested. Timber types are designated by those species oceurring to the extent of 20 per cent or more by number of trees 8 inches and larger in diameter.

The Present Vegetative Cover in Western El Dorado County.-The acreage of the various broad types of forest and nonforest cover found in western El Dorado County is shown in table 2. It will be observed that the vegetation is of three general classes: (1) timber, (2) woodland and chaparral, (3) grassland.

For both the virgin or old-growth and the second-growth timber, some idea of the relative abundance of the several kinds of timber trees may be obtained by referring to figure 6 , in which the timber types are designated by the names of those species occurring to the extent of 20 per cent or more by number of trees 8 inches and larger in diameter. The second-growth timber is of two kinds, even-aged, which consists of practically pure stands of ponderosa pine approximately sixty years old, and all-aged. The first consists of regrowth on lands from which the oldgrowth timber was completely removed or clear-cut during the early mining period, while the all-aged stand is that left on areas logged since that period and on which cutting was only partial or selective. 
Although fires have so thinned out the even-aged timber that only one-fourth of the area is well stocked, there is a total stand of $13 / 4$ billion feet, board measure. This type is illustrated in figure 7 . That the

\section{TABLE 2}

Summary of the Vegetative Cover of Western El Dorado County Lands

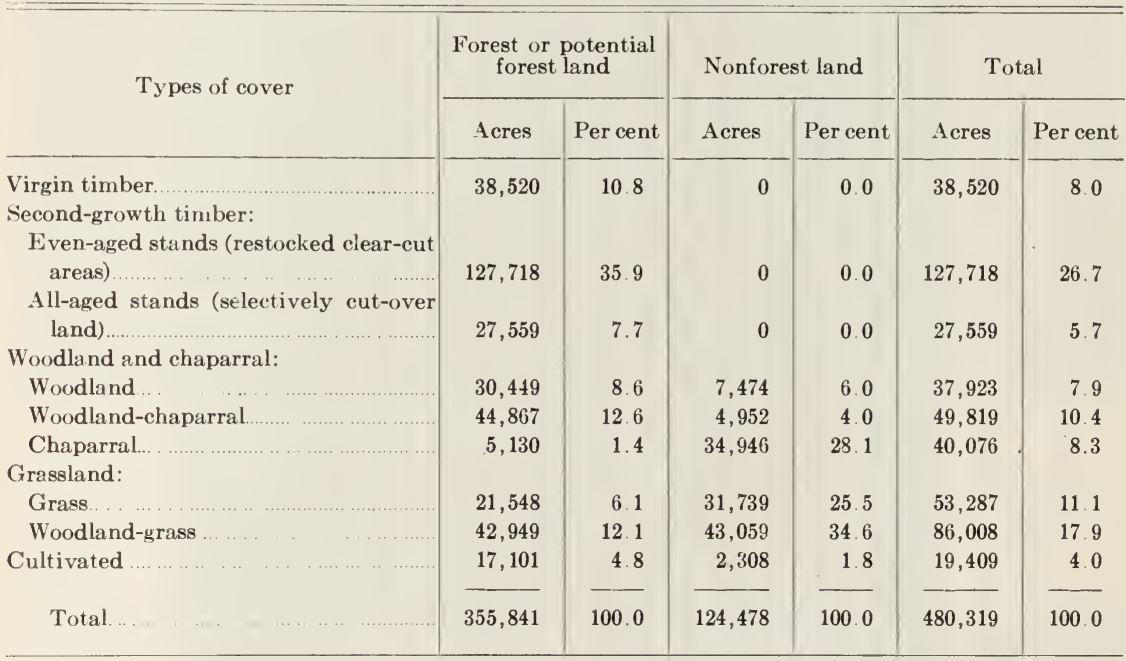

TABLE 3

Condition of Selectively Logged Timber Stands as Indicated by Average of Ten Representative* 1-ACre SaMples

\begin{tabular}{|c|c|c|c|c|c|c|c|c|c|c|c|c|c|}
\hline \multirow{2}{*}{$\begin{array}{c}\text { Site } \\
\text { index } \dagger\end{array}$} & \multirow{2}{*}{$\frac{\begin{array}{c}\text { Size } \\
\text { class }\end{array}}{\underbrace{}_{\begin{array}{l}\text { D.B.H., in } \\
\text { inches }\end{array}}}$} & \multicolumn{2}{|c|}{$\begin{array}{c}\text { Ponderosa } \\
\text { pine }\end{array}$} & \multicolumn{2}{|c|}{$\begin{array}{c}\text { Sugar } \\
\text { pine }\end{array}$} & \multicolumn{2}{|c|}{$\begin{array}{l}\text { White } \\
\text { fir }\end{array}$} & \multicolumn{2}{|c|}{$\begin{array}{c}\text { Douglas } \\
\text { fir }\end{array}$} & \multicolumn{2}{|c|}{$\begin{array}{c}\text { Incense } \\
\text { cedar }\end{array}$} & \multicolumn{2}{|c|}{ Total } \\
\hline & & $\mathrm{D} \ddagger$ & $\mathrm{O} \S$ & $\mathrm{D} \ddagger$ & $\mathrm{O}$ & $\mathrm{D} \ddagger$ & $\mathrm{O} \S$ & $\mathrm{D} \ddagger$ & $\mathrm{O} \S$ & $\mathrm{D} \ddagger$ & $\mathrm{O} \$$ & $\mathrm{D} \ddagger$ & O§ \\
\hline \multirow{3}{*}{70} & \multicolumn{13}{|c|}{ Number of trees per acre } \\
\hline & $4-11 \ldots \ldots$ & 11.4 & 16. 3 & 0.9 & 0.5 & 7.5 & 9.4 & 4.0 & 8.7 & 0.5 & 31.2 & 24.3 & 66.1 \\
\hline & 12 and over & 14.8 & 3.9 & 0.7 & 0.1 & 7.2 & 2.5 & 6.5 & 1.2 & 2.2 & 3.6 & 31.4 & 11.3 \\
\hline Total & & 26.2 & 20.2 & 1.6 & 0.6 & 14.7 & 11.9 & 10.5 & 9.9 & 2.7 & 34.8 & 55.7 & 77.4 \\
\hline
\end{tabular}

* Each sample represents four $1 / 4$-acre circular plots mechanically located 330 feet apart.

$\dagger$ For definition of site index see page 51 .

$\ddagger$ Dominants (D) include thrifty trees on which a net growth can be expected. These trees are so located that they will remain dominant during the next sixty years.

\$ Others $(\mathrm{O})$ include trees on which no net growth can be expected, i.e., over-mature, diseased, badly injured trees, and those trees that will not remain dominant during the next sixty years.

selective logging left the land in a condition by no means unproductive is indicated by table 3, which shows that the average acre in this area has more than 50 vigorous, well-spaced trees larger than 4 inches in 
diameter. This is an average of both northerly slope conditions where the stands are pine-fir mixtures, and southerly slopes where the stands are prevalently of pure pine.

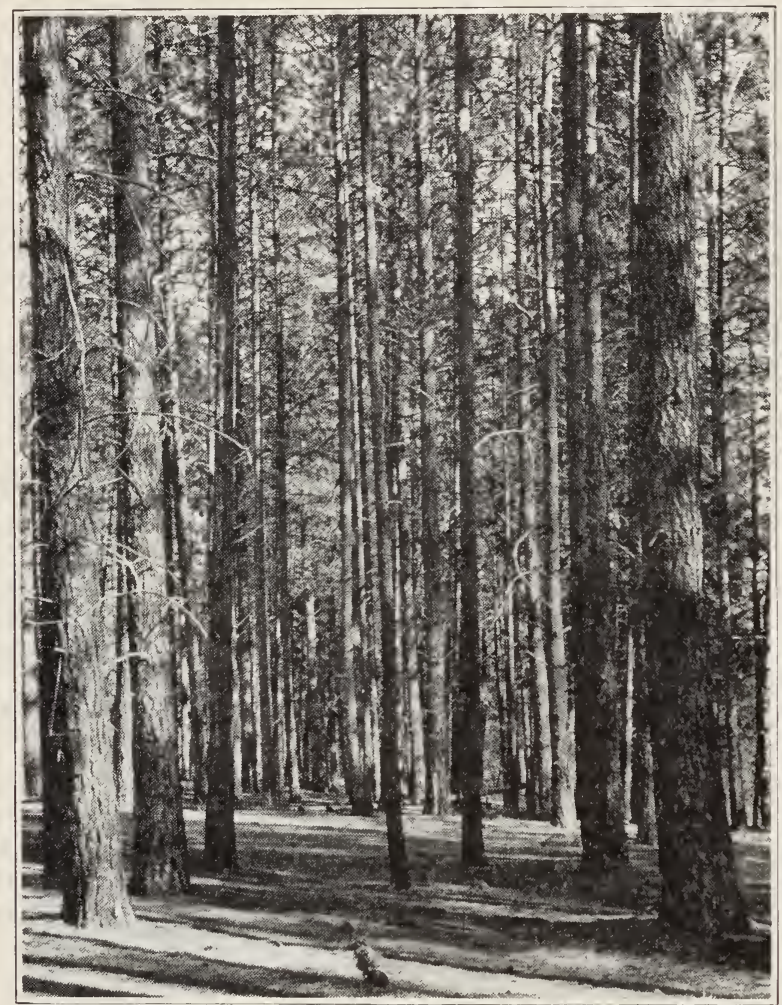

Fig. 7.-An example of a well-stocked stand of sixtyyear-old ponderosa pine near Georgetown in western El Dorado County. The approximate total area of second growth of this age class, including all stands over 10 per cent stocked, is 126,000 acres. This area supports a total estimated stand of about $13 / 4$ billion feet. This estimate is based on manufacture with a $1 / 4$-inch saw kerf and utilization to a top diameter of 4.0 inches inside bark. The latter standard is much beyond present use in our virgin timber but will undoubtedly be attained by the time we come to the utilization of this second growth, as is indicated by present developments where second growth is now being used in the East.

The general vegetative-cover class designated as "woodland and chaparral" may conveniently be divided into three types: woodland, chaparral, and woodland-chaparral. The vegetation of these types forms a cover normally so dense as to render the land of little value for grazing. However, that characteristic makes this class of vegetation a valu- 


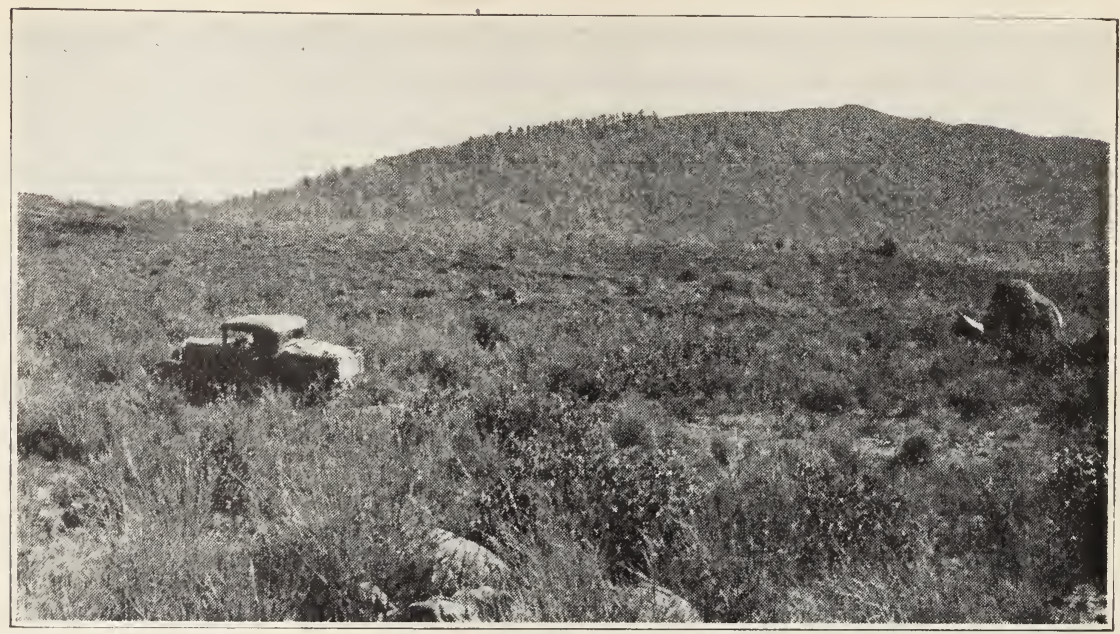

Fig. 8.-A typical chamise brush field, or chaparral, area on nonforest land west of Pine Hill. Although considered in this region an indicator of shallow, sterile, nonagricultural and nonforest soils, chamise aided by fire does take possession of adjoining deep-soiled areas at the expense of either timber or grass.

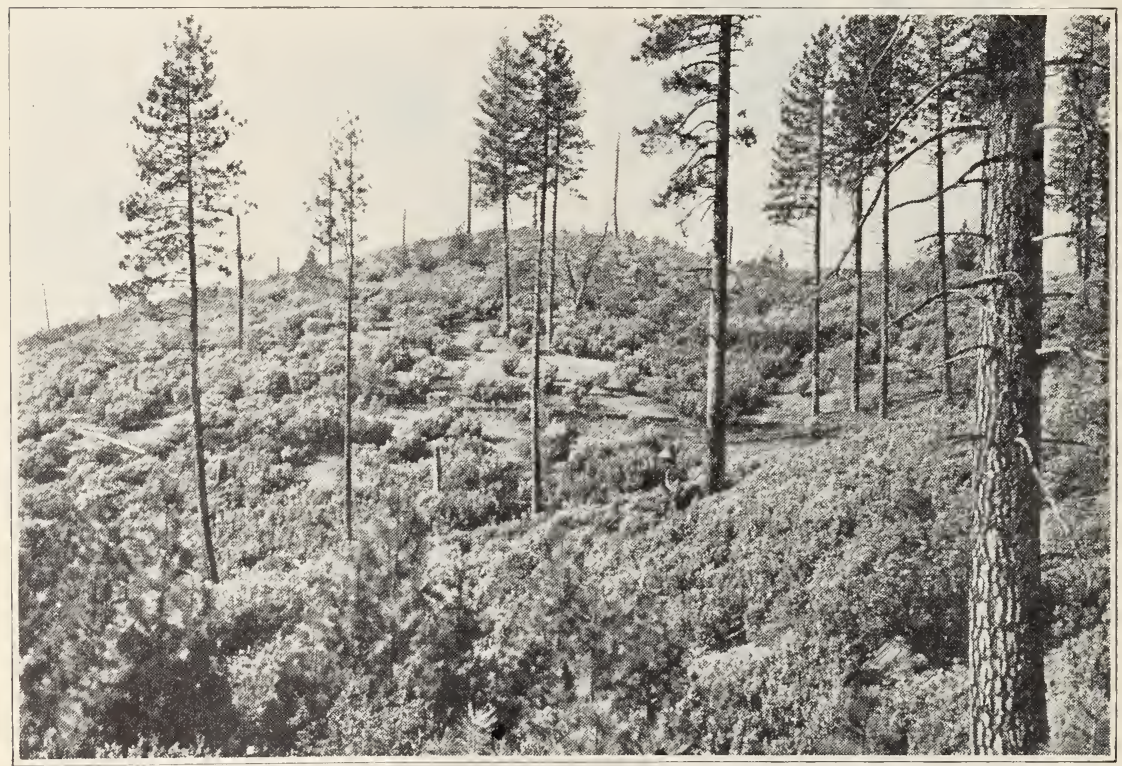

Fig. 9.-This chaparral area near Sly Park is an example of the progressive destruction of second-growth ponderosa pine by fire and its replacement by worthless manzanita brush. A few more fires will complete the work of deforestation. If fires are excluded the area will gradually revert to pine. 
able watershed cover. The woodland is composed of various oaks, black, blue, valley, and interior live oak, with which the Digger pine is frequently admixed. The chaparral, or brush field, cover, similar to that shown in figures 8 and 9 , consists primarily of one or more of three species : chamise, ${ }^{8}$ which in this region is usually confined to the poorest

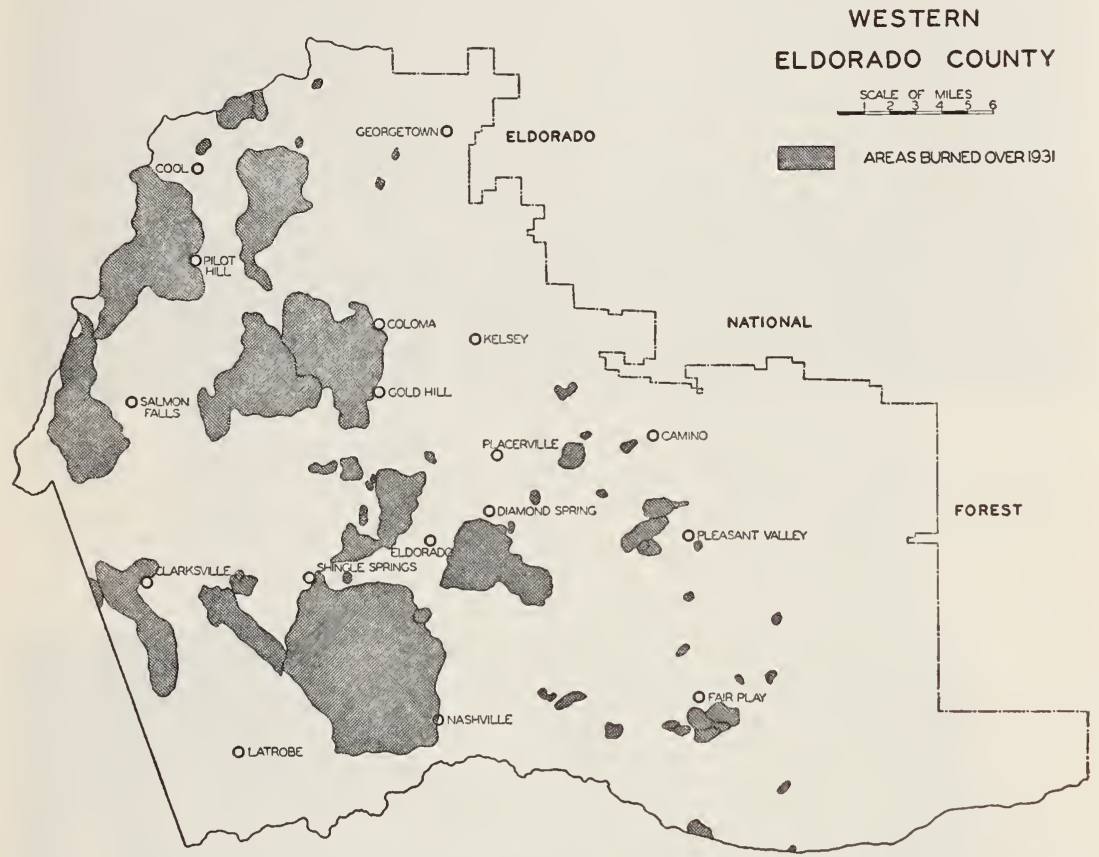

Fig. 10.-During 1931, the year in which the vegetation survey was made, about 73,000 acres, or 15 per cent of western El Dorado County, was burned over as a result of 88 man-caused fires.

soils on nonforest land, manzanita, and buckbrush. ${ }^{9}$ Brush field areas with more or less scattered individuals and clumps of woodland trees are designated as "woodland-chaparral." All of the woodland-tree species except the California black oak are characteristic of nonforest land and have been spread to adjacent forest lands as a result of the frequent fires.

The year 1931, in which this vegetation survey was made, furnished an example of how extensive an area may be burned over in a single season (fig. 10). In that year there were 88 fires, ${ }^{10}$ all man-caused, which burned over about 73,000 acres, or 15 per cent of western El Dorado County. These were summer fires and do not include the so-called "light-

8 Adenostoma fasciculatum.

9 Manzanita = Arctostaphylos vicida; buckbrush = Ceanothus cuneatus.

10 From the official records of the State Division of Forestry, Sacramento. 
burning fires" of late autumn and early winter. If frequent burning continues, these types of cover seem likely to continue to increase in area, at the expense not only of timber but of grass as well.

The grassland types include the grass type proper, which comprises areas on which the principal vegetation consists of grass and herbs, and the woodland-grass type which consists of grass areas with more or less scattered individuals and groups of woodland trees, an example of which may be seen in figure 14 on page 99 .

The grassland area as a whole may be considered as fair grazing land, rather than good, because of the preponderance of low-value, introduced annual grasses such as barbed oats, soft cheat, and fescue, which have replaced the more valuable native perennial grasses and taken over the ground, apparently as a result of fire and overgrazing. An invasion of considerable areas by the obnoxious St. Johnswort (Klamath weed) has resulted in a further deterioration of the range value.

Of the grassland listed in table 2 as potential forest land, the grass type proper occupies mainly once-cultivated lands abandoned to grazing use, while the woodland-grass type is found upon lands where the efforts to keep them partially cleared for grazing purposes have been fairly successful.

\section{THE UTILIZATION OF EL DORADO COUNTY LANDS FOR AGRICULTURE}

From the foregoing discussion of grassland types it may be concluded that in the early development of the county a considerably larger area was tilled than was in such use in 1931. According to the reports of the State Surveyor General, 1863 was the year of maximum crop cultivation. The report for that year showed 31,000 acres cultivated for the county as a whole. Two years later, in 1865, the report of the same official showed only 22,253 acres under cultivation. This was 72 per cent of the area recorded in the peak year. The Census of 1930 records 19,706 acres of crop land for the entire county. Remnants of orchards and vineyards, together with statements of pioneers, are even more convincing than these statistics that there has been a decline in the area of crop land. In addition to the area classified in 1931 as open grassland, much of the area then restocking with second-growth timber had been used for agricultural crops at some time in the past, according to statements of old settlers.

While there had been an important change in the amount and relative proportions of different crops grown, the utilization of El Dorado County crop lands in 1931 resembled, in many respects, the agriculture 
of the pioneer period. Of the cultivated area about one-third was used in 1931 for the production of grain hay. The greater part of the remainder was in orchard crops. The early mining development of the county made agriculture extremely profitable. Hay was grown extensively and profitably for horses and cattle. The large population of the mining days required correspondingly large supplies of fruit and vegetable produce, and transportation from outside was primitive and costly. Accounts are given of individual peach trees which produced fruit valued at more than $\$ 1,000$ in a single year, but that was at a time when a single peach brought as high as $\$ 3.00$ in gold.

As it became necessary to sink mining shafts deeper, gold production became more costly. Also hydraulic mining was restricted by legislative enactments and court decisions. Because of the decline in mining activity, the population in many parts of the county declined. Local demand for food and feed dropped off and competition from adjoining counties increased. Many of the steeper hillsides became badly eroded, vineyards were neglected, crop land became pasture, and pastures were appropriated by brush and trees. Thus, many of the fields cleared under conditions of a temporary economic situation ceased to be cultivated.

Then fruit production became more and more profitable. From some of the small pear orchards planted by the "forty-niners" a number of small fortunes were made. Water diverted by the old mining ditches was turned into irrigation furrows. More land was cleared, trees were planted, and during the World War and the post-war inflation period the fruit and livestock industries of El Dorado County enjoyed another period of prosperity. But now many are beginning to wonder if the county has experienced another "glorious episode," if pear production and gold mining must oceupy a place in history only.

\section{ORCHARD CROPS}

Fresh Pears.-The most important agricultural crop of the county is fresh pears produced for shipment to eastern markets, the Bartlett being the dominant variety and likely to remain so unless driven out by disease. All varieties share in the economic difficulties, which promise to be severe throughout the current decade.

Fortunately only small quantities of the earliest El Dorado Bartletts are marketed during the period when supplies of California Bartletts are the largest and prices the lowest in eastern markets. A large majority of El Dorado Bartletts, because they are grown at elevations which are higher than those of many of the other producing areas, ripen about the latest of any in the state and in recent years have been marketed 
during the latter half of the season when prices have usually been higher than the season's average. However, this advantage of better late-season prices has been declining in recent years. The decline has been due to increased Bartlett production and shipments from Mendocino and Lake counties in California and from the states of Oregon and

TABLE 4

Utilization of the Orchard Solls of El Dorado Countr*

\begin{tabular}{|c|c|c|c|c|c|c|}
\hline \multirow{2}{*}{ Type of soil $\dagger$} & \multirow{2}{*}{$\begin{array}{l}\text { Area } \\
\text { of soil } \\
\text { type }\end{array}$} & \multirow{2}{*}{\multicolumn{2}{|c|}{$\begin{array}{l}\text { Amount of each } \\
\text { soil type in orchard } \\
\text { and vineyard }\end{array}$}} & \multicolumn{3}{|c|}{$\begin{array}{c}\text { Distribution of orchards by } \\
\text { soil types }\end{array}$} \\
\hline & & & & Pears & $\begin{array}{l}\text { Plums } \\
\text { and }\end{array}$ & Peaches \\
\hline Aiken clay loam, deep phase... & $\begin{array}{l}\text { acres } \\
5,706\end{array}$ & $\begin{array}{l}\text { acres } \\
2,241\end{array}$ & $\begin{array}{c}\text { per cent } \\
39.3\end{array}$ & $\begin{array}{c}\text { per cent } \\
27.7\end{array}$ & $\begin{array}{l}\text { per cent } \\
24.5\end{array}$ & $\begin{array}{c}\text { per cent } \\
4.9\end{array}$ \\
\hline Diamond Springs loam & 5,450 & 1,231 & 22.6 & 12.3 & 17.8 & 19.2 \\
\hline 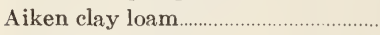 & 17,229 & 1,266 & 7.3 & 10.0 & 3.9 & 5.7 \\
\hline 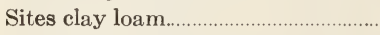 & 28,774 & 1,021 & 3.5 & 9.8 & 4.5 & 4.2 \\
\hline Mariposa silt loam.................. & 5,667 & 810 & 14.3 & 9.8 & $\ddagger$ & 3.2 \\
\hline Holland fine sandy loam.. & 2,538 & 845 & 33.3 & 8. 2 & 13.9 & 15.9 \\
\hline Holland loamy sand............ & 15,052 & 960 & 6.4 & 5.8 & 3.9 & 27.9 \\
\hline 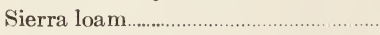 & 3,523 & 490 & 13.9 & 4.7 & 6.1 & 3.2 \\
\hline Sites stony loam & 3,539 & 183 & 5.2 & 2.0 & $\ddagger$ & 0.9 \\
\hline 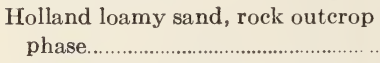 & 11,872 & 205 & 1.7 & 0.6 & 8.9 & 3.4 \\
\hline Aiken clay loam, shallow phase & 35,834 & 588 & 1.6 & 1.8 & 9.4 & 1.5 \\
\hline All others. & 209,811 & 774 & 0.6 & 7.3 & 7.1 & 10.0 \\
\hline Total, all soils.. & 344,995 & 10,614 & 3.1 & 100.0 & 100.0 & 100.0 \\
\hline
\end{tabular}

* Compiled from the crop survey made in 1931 by the Division of Soil Technology, University of California.

$\dagger$ Description of type of soil may be found in: Storie, R. Earl, and D. F. Trussell. Soil survey of the Placerville area, California. U. S. Dept. Agr. Bur. of Chem. and Soils Bul. 34 (15):29. 1927.

‡ Quantity insignificant.

Washington; to increased production of other varieties of pears, such as the Bose (Beurre Bose), which compete somewhat with late Bartletts; and to the increased practice of holding midseason Bartletts in cold storage for later markets, which has resulted in greater competition during the latter part of the season. In the future, therefore, it would appear that the competition which El Dorado Bartletts may expect from other producing areas on the Pacific Coast will be so keen that, over a period of years, prices for El Dorado shipping Bartletts ordinarily may not be expected to be above the state average and may perhaps be somewhat lower. The expansion in Bartlett pear production is likely to continue for some time into the future because of the large acreage of now nonbearing and light-bearing pear trees in this and other Pacific Coast producing areas. In 1930 more than half of the acreage of Pacific Coast Bartletts was in the nonbearing and light-bearing age classes. 
Wide variations in the production of individual orchards are dependent upon cultural methods of the operator, choice of varieties, rootstock, and disease. Besides these individual differences in methods of cultivation, pear yields and quality of fruit are determined by soil

\section{TABLE 5}

Percentage of Different Pear, Plum, and Peaci Varieties Shipped in 1930 fron Different Elevations in El Dorado Countr*

\begin{tabular}{|c|c|c|c|c|c|}
\hline \multirow[t]{2}{*}{ Kind and variety } & $\begin{array}{c}\text { All } \\
\text { elevations }\end{array}$ & $\begin{array}{c}\text { Elevation } \\
500 \text { to } 1,500 \\
\text { feet }\end{array}$ & $\begin{array}{c}\text { Elevation } \\
1,500 \text { to } \\
2,000 \text { feet }\end{array}$ & $\begin{array}{l}\text { Elevation } \\
2,000 \text { to } \\
2,800 \text { feet }\end{array}$ & $\begin{array}{l}\text { Elevation } \\
\text { above } \\
2,800 \text { feet }\end{array}$ \\
\hline & \multicolumn{5}{|c|}{ Percentage based on total for all elevations } \\
\hline All pears $\dagger .$. & 100.00 & 6.82 & 25.27 & 51.11 & 16.80 \\
\hline Bartlett .... & 100.00 & 6.8 & 24.7 & 49.4 & 19.1 \\
\hline Bosc ................... & 100.00 & 2.7 & 34.2 & 543 & 8.8 \\
\hline Winter Nelis.... & 100.00 & 44 & 14.0 & 76.6 & 5.0 \\
\hline Anjou & 100.00 & 0.4 & 29.6 & 66.8 & 3.2 \\
\hline Hardy $\ldots \ldots \ldots \ldots$ & 100.00 & 0.8 & 48.5 & 486 & 21 \\
\hline Forelle........ & 100.00 & 2.9 & 412 & 55.6 & 03 \\
\hline Comice & 100.00 & 0.0 & 37.4 & 41.8 & 208 \\
\hline Raphael & 100.00 & 0.0 & 00 & 100.0 & 00 \\
\hline Other pear varieties & $\ddagger$ & $\ddagger$ & $\ddagger$ & $\ddagger$ & $\ddagger$ \\
\hline All plums $\dagger \ldots$. & 100.00 & 1883 & 4023 & 40.17 & 077 \\
\hline President & 100.00 & 119 & 478 & 35.8 & 45 \\
\hline Gros prune & 100.00 & 8.2 & 30.2 & 39.1 & 22.5 \\
\hline Grand Duke .... & 100.00 & 304 & 340 & 30.4 & 52 \\
\hline Kelsey ….............. & 100.00 & 15.7 & 470 & 37.3 & 00 \\
\hline Giant ................. & 100.00 & 425 & 378 & 19.7 & 00 \\
\hline Burbank ...... & 100.00 & 93.7 & 6.3 & 0.0 & 00 \\
\hline Tragedy $\ldots \ldots \ldots$ & 100.00 & 15.6 & 149 & 69.5 & 00 \\
\hline 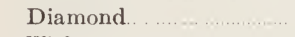 & 100.00 & 56.0 & 440 & 0.0 & 00 \\
\hline Wickson $\ldots \ldots \ldots \ldots$ & 100.00 & 28 & 960 & 12 & 00 \\
\hline Other plum varieties & $\ddagger$ & $\ddagger$ & $\ddagger$ & $\ddagger$ & $\ddagger$ \\
\hline All peaches $\dagger . .$. & 100.00 & 7.02 & 7426 & 1812 & 0.60 \\
\hline Elberta ............... & 100.00 & 3.6 & 90.7 & 5.6 & 0.1 \\
\hline Orange Cling $\ldots \ldots \ldots$ & 100.00 & 6.5 & 69.3 & 241 & 01 \\
\hline Levy Cling & 100.00 & 5.2 & 59.7 & 350 & 0.1 \\
\hline Strawberry Cling & 100.00 & 23.5 & 67.9 & 8. 6 & 0.0 \\
\hline J. H. Hale .................. & 100.00 & 6.6 & 73.2 & 202 & 0.0 \\
\hline Phillips Cling.. & 100.00 & 0.0 & 73.4 & 266 & 0.0 \\
\hline Other peach varieties....... & $\ddagger$ & $\ddagger$ & $\ddagger$ & I & $\ddagger$ \\
\hline
\end{tabular}

* Figures in this table do not include shipments by truck to San Francisco.

$\dagger$ The production of each grower was located on a map of the county. Elevations were obtained from United States Geological Survey quadrangles. Fruit production records are from Placerville Fruit Growers' Association, Earl Fruit Company, Pacific Fruit Exchange, Gerard Fruit Company, Sgobel and Day, Fruit Distributors, and Auburn Fruit Exchange.

$\ddagger$ Quantity insignificant.

conditions and climatic influences; the latter in turn are affected by elevation. Table 4 shows the distribution of El Dorado County pear acreage and that of other fruits by soil types. This distribution can be explained by a consideration of climatic and water limitations. 
More than two-thirds of the pear acreage of the county is situated at elevations between 2,000 and 3,000 feet. Higher prices, resulting from the later time of shipment, that have been enjoyed by producers situated

\section{TABLE 6}

Total Shipments of Pears, Plums, and Peaches by Varieties From El Dorado County, 1930

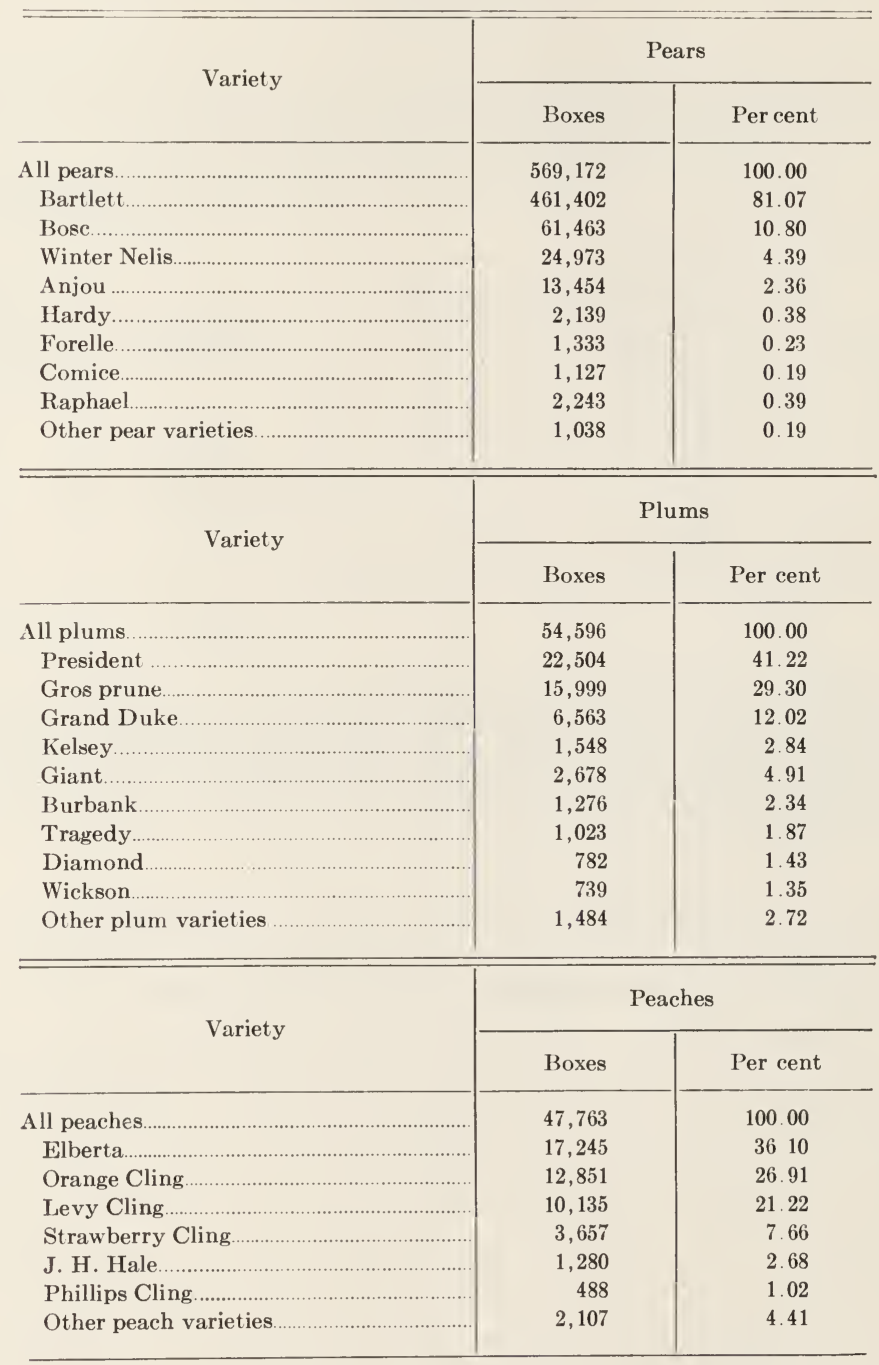

between elevations of 2,000 and 3,000 feet, in comparison with prices received by El Dorado County producers situated below the 2,000-foot elevation, have been offset hy climatic hazards. However, many of the 
orchards at lower elevations are subject to frost damage. Not only is elevation important from the standpoint of the general altitude of the orchard, but also the situation of the land with respect to adjoining topography may determine the extent of damage by frost and freezing temperatures. A freeze may result from a cold wind from the mountains or a cold air pocket in the bottom of a ravine. Table 5 shows the per-

\section{TABLE 7}

Percentage of Trees of Different Ages in 1931 in Twentr-one Orchards of El Dorado County, and Estimates of Similar Percentages for the Orchard if Operated on a Sustained-Production Basis

\begin{tabular}{|c|c|c|}
\hline \multirow[b]{2}{*}{ Age of trees, in years } & \multicolumn{2}{|c|}{$\begin{array}{c}\text { Per cent of total acreage occupied by } \\
\text { trees of specified ages }\end{array}$} \\
\hline & $\begin{array}{c}\text { Twenty-one } \\
\text { orchards* (actual } \\
\text { observation) }\end{array}$ & $\begin{array}{c}\text { Sustained } \\
\text { production } \\
\text { (estimated from } \\
\text { observed } \\
\text { mortality rate) }\end{array}$ \\
\hline 0 to $3 \ldots \ldots \ldots \ldots \ldots \ldots$ & 14.0 & 12 \\
\hline 4 to $7 \ldots \ldots \ldots \ldots \ldots$ & 10.1 & 11 \\
\hline 8 to $14 \ldots \ldots \ldots \ldots \ldots \ldots \ldots$ & 27.2 & 21 \\
\hline 15 to $28 \ldots \ldots \ldots \ldots$ & 31.7 & 26 \\
\hline & 100.0 & 100 \\
\hline
\end{tabular}

* The age distribution of these twenty-one orchards is not exactly representative of the ages of pear trees for the county as a whole, for the farms were selected at random from those of the county having six years of production record. They are, however, more representative of the situation as it is likely to develop than if the very young orchards had been included. The differences in the two columns are due to heavy plantings in the years 1918,1919 , and 1920, to a rate of planting in an earlier period greater than necessary for the maintenance of sustained production, and to the destruction of many mature trees by blight in recent years.

centage of shipments of the different varieties of pears and of other fruits in relation to elevation. It is significant that 83 per cent of all pear shipments were from elevations below 2,800 feet.

Income From Pears.-Advance estimates of income that would be received from trees in their prime have led to many unwise investments. In the Bartlett pear orchards of the county the maintenance of the orchard on a basis of sustained production will require an age distribution approximately that given in table 7 . About two-thirds of an orchard maintained on such a basis is in a medium to heavy-bearing age group. The remainder consists of blank spaces or of trees which are very young or very old. Costs apply to nonbearing as well as to the bearing trees. Therefore, commercial yields must be considered on the basis of the entire area in pears.

In table 8 are given estimated commercial yields at different elevations on the deep residual soil of the Camino Ridge extending above 
Placerville to Camino and on the higher ridges west of Placerville. Yields are also given for less favorable situations. These estimates are for orchards having the age distributions required for sustained production. Orchards in their prime will exceed these estimates.

On the basis of the yields for orchards situated more favorably with respect to frosts, estimates of gross income from a 30 -acre pear orchard have been made for different prices and for different elevations. These are given in table 9 .

TABLE 8

Estimated Average Yields per Acre in the El Dorado County Pear Orchards Having Young Trees to Replace Those Removed by Disease or Old Age*

\begin{tabular}{|c|c|c|c|}
\hline & \multirow{2}{*}{$\begin{array}{l}\text { 1926-1929 average } \\
\text { for areas having } \\
\text { good air drainage }\end{array}$} & \multicolumn{2}{|c|}{$\begin{array}{l}\text { Average computed on basis of estimated } \\
\text { crop losses over period of years }\end{array}$} \\
\hline Elevation & & $\begin{array}{l}\text { Relatively high } \\
\text { elevation, good air } \\
\text { drainage }\end{array}$ & $\begin{array}{l}\text { Relatively low } \\
\text { elevation, poor air } \\
\text { drainage }\end{array}$ \\
\hline $\begin{array}{l}\text { feet } \\
1,500\end{array}$ & \multirow{4}{*}{$\begin{array}{c}\text { packed boxes } \\
348 \\
306 \\
254 \\
192\end{array}$} & \multirow{4}{*}{$\begin{array}{c}\text { packed boxes } \\
325 \\
260 \\
178 \\
134\end{array}$} & \multirow{4}{*}{$\begin{array}{c}\text { packed boxes } \\
244 \\
214 \\
\dagger \\
\dagger\end{array}$} \\
\hline $2,000 \ldots$ & & & \\
\hline 2,500 & & & \\
\hline $3,000 \ldots \ldots \ldots \ldots \ldots \ldots \ldots \ldots$ & & & \\
\hline
\end{tabular}

* Probable losses from frost are taken into account. Years of no yield are averaged in with good years. $\dagger$ No orchards in such situations.

Cost of Developing the Pear Orchard.-In 1930 the farmer who had developed a 30 -acre pear orchard through its fifth year had invested in labor and capital approximately $\$ 670$ an acre exclusive of the cost of his land, the cost of clearing it, and the cost of his residence. The investment in the orchard included the leveling of the land and removal of rocks, the construction of the farm irrigation system, nursery stock, cost of planting, cultivation costs during the period of development, fences and buildings other than the residence, and overhead costs such as interest on capital during the five-year period, irrigation tolls and taxes, county tax, depreciation, etc.

Relation of Costs and Returns to the Utilization of Land for Pear Production.-In 1930 the cost of operating the 30-acre pear orchard exclusive of the operator's wages and interest on the investment was estimated as approximately $\$ 100$ an acre. Table 9 shows the gross incomes which would be obtained at various prices and with various yields. The incomes that would be entirely absorbed in payment of operating costs are given in italics. Producers in this group who receive an income from outside sources sufficient to provide living costs and interest will be able to keep their orchards if the family is so constituted that the equivalent of the full time of one man can be devoted to farming operations in addition 
to the energy required to produce the outside income. If costs remained as in 1930 most farms would go out of production with a continuation of the prices of 1932 , which were a little above $\$ 0.30$ a box net to the growers. Even at $\$ 0.50$ a box, if such a price should continue over a long period, there would be little inducement for growers to continue above the 2,400 -foot elevation. At $\$ 0.70$ the average 30 -acre orchard up to the

\section{TABLE 9}

Estimated Gross Incone from 30-Acre Bartlett Pear Orchards in El Dorado County Located at Different Elevations Under

Different Price Conditions*

\begin{tabular}{|c|c|c|c|c|c|c|c|}
\hline \multirow[b]{2}{*}{ Elevation } & \multirow{2}{*}{$\begin{array}{l}\text { Commercial } \\
\text { production } \\
\text { per acre }\end{array}$} & \multicolumn{6}{|c|}{ Price per box (net to grower) } \\
\hline & & $\$ 0.30$ & $\$ 0.50$ & $\$ 0.70$ & $\$ 0.90$ & $\$ 1.10$ & $\$ 1.30$ \\
\hline feet & boxes & dollars & dollars & dollars & dollars & dollars & dollars \\
\hline $3,000 \ldots$ & 134 & $1,206 \dagger$ & 2,010 & 2,814 & 3,621 & 4,422 & 5,226 \\
\hline $2,800 \ldots$ & 149 & 1,338 & 2,235 & 3,126 & 4,020 & 4,920 & 5,811 \\
\hline 2,600 . & 168 & 1,512 & 2,529 & 3,528 & 4,533 & 5,544 & 6,552 \\
\hline 2,400 . & 192 & 1,728 & 2,880 & 4,029 & 5,184 & 6,336 & 7,485 \\
\hline $2,200 \ldots$ & 226 & 2,031 & 3,390 & 4,746 & 6,105 & 7,458 & 8,820 \\
\hline $2,000 \ldots$ & 260 & 2,340 & 3,900 & 5,460 & 7,020 & 8,580 & 10,140 \\
\hline $1,800 \ldots$ & 294 & 2,643 & 4,410 & 6,174 & 7,938 & 9,702 & 11,466 \\
\hline $1,600 \ldots$ & 318 & 2,862 & 4,770 & 6,675 & 8,583 & 10,494 & 12,402 \\
\hline
\end{tabular}

* Orchard operated on a sustained-production basis.

† Italics: Below amount required for 1930 operating cost exclusive of operator's wages, interest, and rent. Ordinary type: Below amount required for 1930 operating costs, operator's wages, interest, and rent. Black-face type: Above amount required for 1930 operating costs, operator's wages, and interest.

3,000-foot level would return enough to pay actual costs of operation, but at that elevation nothing would be left for the operator's wages and interest. At $\$ 1.30$ a box the average producer at the 3,000-foot level, averaging years of total loss with the others, could obtain the modest income of $\$ 900$ a year and 6 per cent interest on his investment. His skillful neighbor could do better than this. His less skillful neighbor would not do so well.

A drop of 25 per cent in costs, pear prices remaining the same, would raise the margin of profitable cultivation to a point about 400 feet higher up the slopes towards the mountains. Through the severe economic conditions now prevailing, however, many orchards are being neglected or debts for maintenance are being accumulated.

Notwithstanding these perplexing difficulties the following broad conclusions can be drawn :

1. During the next decade or two, pear orchards in the vicinity of Camino can remain under cultivation only if supplemented by income from outside sources. Even if investments are written off and if farms change hands through foreclosures, supplementary sources of income 
will be necessary if orchards are to be maintained in a productive condition (fig. 3, page 12).

2. In the immediate vicinity of Diamond Springs and Placerville, the location of which may be seen in figure 3 , pear production will probably become dependent upon the maintenance of supplementary sources of income.

3. On the more extensive tracts of productive soils to the east of Placerville, if not too high, and on lands lying to the west on the higher elevations as compared to adjoining lands, Bartletts probably will not only be able to compete with other varieties of pears, but probably also will be more profitable in the long run than other kinds of fruit, especially on the Camino Ridge between elevations of 2,000 and 2,800 feet.

4. Prospective returns for investments of land, labor, and capital will not justify further orchard development for many years.

Other Orchard Crops.-Price conditions during the next few years may increase the relative importance of freestone peaches and plums. The only potential competitors which have been suggested are apples and Franquette walnuts. The economic situation of the walnut industry and the wide range of situations adapted to the walnut does not warrant. serious consideration of forcing that erop into the higher elevations. The uncertainty of the apple market is not an encouragement to extensive plantings although a number of varieties have shown their adaptation to the higher elevations. Table 4 shows the distribution of EI Dorado County peach orchards with respect to soil types.

It is below the 2,000-foot level that peaches, plums, and cherries come into the picture. Above this elevation, in 1931, most of the peach orchards were being reduced to the status of the family orchard. A fine quality of Hales and Salways is being produced at elevations of 1,500 to 2,000 feet. Table 5 gives the distribution of different peach varieties with respect to elevation.

In recent years gross and net returns from peaches in this locality have been far lower than from pears. The advantage in favor of pears, however, is likely to be diminished in the next few years. The expansion of the fresh-peach industry of the state has not taken place on a basis comparable to other fruits. Upon the return of normal business prosperity the freestone-peach orchards below Placerville should stand in a somewhat more favorable economic position relative to other fruits than they did during the post-war years prior to 1930 .

Low gross returns per acre for plums coupled with a high mortality of plum trees has discouraged rapid expansion in this fruit particularly at the higher elevations. President and Grand Duke plums and Gros (Pond Hungarian) prunes constituted 82 per cent of the fresh-plum 
and prune shipments in 1930. The distribution of plums and prunes with respect to soil types is shown in table 4 . As with the other fruits, distribution on the different soil types is influenced by climatic conditions. Not only is this true, but also different varieties of plums and prunes respond differently to climatic conditions. A little more than 60 per cent of the plums were produced below the 2,000-foot elevation, while a similar percentage of the Gros prune crop was produced above that elevation. Distribution of prunes and plums with respect to elevation is given in greater detail in table 5 . Difficulty has been experienced because of the sensitiveness of the best plum varieties to location.

Cherries have been confined to a small area in the northwestern part of the county where climatic conditions and nearness to a cherry-shipping community at Auburn probably account for the fact that a number of farmers of a small area in this locality specialize in the production of this fruit. About 90 per cent of the present acreage is distributed on the three soil types, Aiken clay loam, Aiken clay loam shallow phase, and Sierra loam. The entire cherry-producing area lies below the 1,500foot elevation.

- Opportunity for Expanding the Fruit Acreage.-The more important orchard soils and the extent of their utilization for that purpose are listed in table 4. About 93 per cent of the orchard area is on these 11 soil types which comprise 28 per cent of the gross area of the soil survey. Less than 8 per cent of these soils is in fruit crops. Of the 125,340 acres of these soils not in orchard and vineyard, about 75,000 acres are deep residual soils of fair to good quality. Their future use for fruit production would require more favorable prices than seem likely to be realized, also a considerable amount of land clearing, a low-cost water supply, which for a large part of these soils is not available, and more favorable climatic conditions than those which affect a large proportion of these lands situated at the higher elevations.

\section{IRRIGATION}

The 1930 Census reported 10,134 acres irrigated in El Dorado County. About two-thirds of this acreage was included within the El Dorado Irrigation District extending above and below Placerville. (See fig. 11, page 61.$)$

The El Dorado Irrigation District.-This district was organized in 1925. Most of the canals and structures are those of the El Dorado Water Company, which was the last of a series of eight companies or individuals who at different times have owned the properties. The works were constructed many years ago primarily for mining purposes.

In 1927 , bonds were voted to the extent of $\$ 1,300,000$; in that same 
year $\$ 688,000$ worth were issued and sold. Because of financial problems arising from the economic depression, decline in the value of irrigation-district securities, and difficulties in earrying out proposed construction programs, the district defaulted in 1933 in the payment of interest on its outstanding bonds.

Inasmuch as the payment of interest on and retirement of these bonds is dependent upon the collection of irrigation charges levied upon the land, it is of importance to consider these charges and their significance in relation to the utilization of the land. Land included within the irrigation district, whether it is irrigated or not, is subject to assessment for annual operating costs and for the retirement of bond principal. All lands except those occupied by canals and roads have accordingly been taxed by the district in proportion to their assessed value. In addition, a water toll has been charged, the rate depending upon the manner in which the water has been delivered. Thus, all of the lands within the district are subject to the tax, while the toll applies to those lands actually irrigated. In taxing the unirrigated land the assumption has been that the irrigable land has an increased value because of the possibility of its irrigation. The unirrigable land has probably been considered more productive if used in connection with irrigated land.

The methods of utilizing unirrigated land, which prevailed during the first eight years of the existence of the district, did not indicate any striking tendency on the part of farmers to use the dry lands within the boundaries of irrigated farms any more intensively than was the practice on entirely unirrigated farms. In fact, in most cases the opposite tendency seemed to prevail. Where dry land was the sole means of subsistence, it was more completely utilized.

A more complete and productive utilization of the dry lands within the irrigation projects appears to be possible if their grazing resources are used in connection with a limited amount of pasturage of orchard covercrops or hay production from them. Where it is feasible, such utilization, while it may require some increase of irrigation water, may provide additional products for the farmer's table, protect the orchard soils from erosion, and aid in the maintenance of their fertility through a period when cash for the purchase of commercial fertilizers may be lacking.

Until a practice is established which involves the more intensive use of the dry land on irrigated farms in conjunction with the irrigated land, it seems proper to estimate per acre irrigation costs on the basis of the total irrigation assessment including the tax on unirrigated land. In 1930 fourteen water users distributed throughout the district paid for each acre irrigated an average of $\$ 9.58$ toll and an additional $\$ 1.52$ 
tax. This tax included that paid on both irrigated and unirrigated land hut is here computed on the basis of the total amount of tax paid for each acre irrigated. Adding this toll and tax gives a total of $\$ 11.10$ per acre for each acre irrigated. Water use on these farms averaged 1.7 acrefeet per acre. For the district as a whole, annual costs averaged about $\$ 13.00$ for each acre irrigated. Payments by absentee landowners and users of water for other than irrigation purposes accounted for the difference noted in comparing the cost on farms with the district average. In 1930 the annual costs of the system amounted to nearly $\$ 80,000$, about half of which represented interest and bond discount.

During the period 1930 to 1932 , when returns to farmers were rapidly declining, effective measures were taken to reduce operating costs. To some extent this resulted in a curtailment of services. On the other hand, it is reported that genuine economies were effected. Up to 1933 bond interest was paid when due, but default was imminent.

The assessments levied upon lands within the irrigation district are of significance with respect to the utilization of the land. The planning of utilization and the bringing about of economic adjustment are of greater importance within the district than outside because all of the land within the district is affected to a greater degree by the efficiency of the utilization of any part. Furthermore, failure to obtain the maximum return from the land is soon reflected in delinquency and impairment of bond security. One of the most important economic problems of this area is the building up of the financial position of the district as a whole. This phase is considered further on page 75.

Rapid agricultural development in an irrigation district is of utmost importance from the standpoint of district financing. Thus, there is a tendency for land within an irrigation district to be utilized for irrigated crops as early as possible. Much of the financial difficulty of American irrigation has been due to slow project development. The question arises, therefore, whether or not a program of rapid development of the unirrigated irrigable land in this district would be feasible.

The gross area of the irrigation district, which is a little less than 30,000 acres, comprises the largest body of deep residual soils within the county. Fifty-two per cent, or about 15,600 acres, of this area in 1931 was still in timber and brush. A little more than 6,000 acres, or 20 per cent, were then reported under irrigation. There remained unirrigated an area of approximately 10,000 acres of land, which from the standpoint of its physical character is irrigable. In 1931 the engineering department of the district estimated that with the Weber Creek Reservoir in operation the district could supply 7,500 acres with an adequate water supply. This estimate, however, assumed a continued utilization 
of irrigated land largely for orchard crops requiring approximately 1.7 acre-feet of water per acre annually. It was also estimated that upon completion of the Weber Creek Reservoir and the irrigation of 1,500 acres of additional land, the bonded indebtedness would be increased to $\$ 1,000,000$ or $\$ 133$ for each acre irrigated. If the bond schedules contemplated in 1931 should be adopted, bond principal after 1947 would be added to the annual charges, which prior to that year would include only operation costs and interest. It is estimated that this would bring the total annual charges up to $\$ 18$ for each acre irrigated. All of these charges would not be assessed to irrigation farmers, however, for nonresident landowners and users of water for domestic and industrial purposes would contribute approximately 15 per cent of their payment.

A detailed and comparative estimate of costs and returns that would result from expansion to the full irrigable acreage of the district, as compared with costs and returns involved in farming the present acreage, is not necessary for arriving promptly at a negative conclusion regarding the wisdom of such expansion. Expansion of the irrigated area to the ultimate 16,000 acres would necessarily be accompanied by expenditure by the district for additional water supplies. Available estimates of construction costs indicate that a higher rather than a lower financial burden per acre would result from such expansion. When these facts are taken into consideration with the estimates of costs and returns involved in fruit farming previously presented, the possibility of further development on an economic basis seems very remote.

The Diamond Ridge Water Company.-Within the area adjacent to the town of Diamond Springs are approximately 1,600 acres of irrigable land, about 25 per cent of which is now in orchards. These orchards, since they were first irrigated, have always suffered from a water shortage in the latter part of the season. The matter of supplemental water supply for the Diamond Ridge system has been the subject of repeated attempts at extensive development, involving thousands of acres of land extending beyond the western boundary of the county. If some conservative plan could be developed whereby industries and agriculture under the Diamond Ridge Ditch could be given a late-season water supply, the temptation for further extensive development of another large irrigation system would be removed.

Other Irrigation Areas.-Other irrigation systems within the county include a ditch serving about 76 water users near Georgetown, Cool, and Pilot Hill; a ditch owned by a half-dozen farmers serving about 28 orchards near Coloma; and a ditch about 12 miles long at the western boundary of the county, serving 4 or 5 farmers. With the exception of 
the Coloma Ditch, these serve areas which are not completely developed, but in which rolling topography, high elevation, or difficult land-clearing will require very favorable prices to make feasible the construction costs which would be necessary to provide additional water supplies.

These small irrigation systems are all performing a distinct service in the areas which they supply. Improvement in the carrying capacities of irrigated pastures appears to be possible. Efforts directed at such improvement would strengthen the livestock industries and would make more profitable the utilization of adjacent unirrigated areas. The experience of the El Dorado Irrigation District will prevent any immediate movement to expand the acreage under these smaller systems. Future expansion of these projects, inspired by temporary high prices, could entirely destroy the value which they now have in the production of supplementary feeds for livestock, by increasing the water costs to a prohibitive point for such use. The economical utilization of the large adjoining areas of unirrigable land requires this utilization of the irrigated lands in these areas. Any diversion of such irrigated lands to orchard or other independent uses would result in unbalanced utilization of the areas as a whole, and would be of doubtful profit.

\section{GENERAL CHARACTERISTICS OF THE LIVESTOCK INDUSTRIES}

Extent of Livestock Farming.-By far the greater part of El Dorado County is not suited to irrigation farming. Although some fruits are produced without irrigation, most of the dry farming is carried on in connection with livestock production. Therefore, livestock farming, at least as far as extent of area is concerned, is the most important agricultural industry of the county.

Notwithstanding the fact that only 29 per cent of western El Dorado County is open and woodland grass, more than 50 per cent of that part of the county is in farms used primarily for the production of livestock and livestock products, while much of the land owned by nonresidents provides a certain amount of free forage for neighboring herds. In addition to the farms devoted primarily to livestock production, there are other types of farming which include livestock as an important part of the farming program. The extent of livestock farming in the county is also indicated by the amount of pasture land within farms. In 1930 the Census reported more than 83 per cent of the land in El Dorado County farms as pasture land. Private and public lands within the Eldorado National Forest, 73 per cent of which lies within the county, were also used for grazing. In the summer of 1930 about 7,000 eattle and 15,000 sheep were pastured in the county on the public lands of the National Forest. 
Thus, the livestock-farming area of El Dorado County is determined by the grazing resources which include extensive grass and browse pastures, both public and private, on farms and on idle lands ${ }^{11}$ adjacent to farms, as well as on the ranges within the Eldorado National Forest boundaries. The extent and condition of these grazing resources have already been discussed. However, the extent of the area of these pasture lands is not an adequate measure of their importance or significance to the livestock industries in different parts of the county. A knowledge of the carrying capacities, the time when feed is available, the different systems and types of livestock farming, sizes of enterprises, costs of operation and returns, and the relation of these to the character of the land is essential to a clear understanding of the conditions under which livestock production in El Dorado County may continue to be profitable. Knowledge of this kind is also necessary before it is possible to judge which areas, in the long run, will be able to continue in the production of livestock.

Grazing Capacities.-On ranches operated on the basis of an eightmonths' grazing season where very little supplementary feed is used, carrying capacities range from 10 acres to the animal on the open grasslands near the Sacramento County line to about 26 acres to the animal in the Fairplay and Aukum country, where shorter growing season and light soils reduce the amount of feed available. On the Georgetown Ridge between the South Fork and Middle Fork of the American River, where open grassland is available for pasture, lands situated at corresponding elevations and pastured during a season of eight months have grazing capacities similar to those south of the American River. A smaller percentage of this area is adapted to grazing, however, and average carrying capacities are much lower. Throughout the whole of the western part of the county, but particularly on the Georgetown Ridge, are extensive brush-covered mountainous areas, which are not capable, in their present condition, of grazing any substantial number of livestock, and which depend upon the adjoining tracts or upon income from outside sources to keep them off the tax-delinquency list. Where cattle are pastured twelve months a proportionately greater number of acres are required. On some of the ranges operated on a twelve-months' basis more than 40 acres are required for one animal.

The Grazing Season.-On the valley floor, as in Sacramento County and extending a short distance into El Dorado County, winter feed is available under normal conditions from November 11 to May 15 . In the region directly east of this area and centering around Shingle Springs,

11 These lands are idle only so far as they bring little or no agricultural income to their owners. 
the grazing season is at its best usually between May 15 and July 15. In the region of Pleasant Valley, Aukum, and Fairplay, stock finds good feed as a rule from June 1 to August 10. On the higher ranges, which are mainly within the National Forest, the Forest Service official grazing season is from August 11 to October 31, although there is feed ready on the lower part of this range before the August date. The deferring of the grazing season as elevation increases has had an important influence upon the general systems of ranching.

Ranching Systems.- In the western part of the county as a whole, a number of ranching systems may be found, the characteristics of which have been largely determined by the availability, amount, kind, and source of summer feed. The amount, quality, and timeliness of feed have been determined largely by the physical character of the land. The ranching systems may be described briefly as follows:

1. Nonmigratory herds maintained by forage crop and grazing: Livestock are kept the year round, and all or nearly all of the hay fed is produced in the foothill area. For the most part these are small enterprises.

2. Migratory herds :

a) All grazing: Range in the mountains provides summer feed but no feed is raised. These are strictly grazing enterprises.

b) Grazing supplemented by crop feeds: The ranch may be operated jointly with a large enterprise in the Great Valley; the headquarters may be either in the foothills or in the Valley. Or the operator may graze his livestock in the mountains during the summer months and put up in the foothill area all or nearly all of the necessary hay. Some use is made of irrigated pasture, but most of the hay is dry-farmed grain hay. In a few instances vetch with oats has proved successful.

Types of Livestock Frarms.-The general systems of operation described above apply to sheep, beef, dairy, dairy and beef, beef and sheep enterprises, and to general, diversified livestock farming. About 60 per cent of the land in livestock farms, or roughly one-third of the entire land area west of the National Forest boundary, is utilized in the production of beef and dairy products. Slightly more than one-fifth of the area in livestock farms or a little more than one-tenth of the total land area below the National Forest is used for sheep production. The remainder of the livestock-farm area is included in various types of diversified livestock farms.

Beef production in El Dorado County is for the most part a stockraising industry. While some young stock is purchased for fattening on the range or by feeding, most of the beef animals sold for slaughter are raised by the owners who fatten them for market. 
Dairying in the county is carried on in a number of different ways. There is the intensive type which supplies whole milk to the Placerville area; the purely grazing migratory type, frequently carried on in connection with beef production, which supplies cream to the Sacramento market in the fall, winter, and spring and to the summer campers in the summer months; and the diversified livestock and dairy farm which produces erops to supplement the pasture land and which obtains its income from the sale of eream, hogs, poultry products, and sometimes a little fruit.

In the case of the first of these the market is limited and well supplied. The second type is of intermediate importance. Until the business depression set in these migratory dairy herds were making a very good showing. Their summer market for whole milk was growing rapidly. Their continued success depends upon the future trend in recreational development in the high Sierras and the extent of future competition. The third type of dairy enterprise is of particular interest with respect to the general problem of land utilization in El Dorado County.

Diversified farming promises to solve the supplementary feed problem for the smaller-seale enterprises in the areas having combinations of deep and shallow soils, together with smooth and rough topography, leaving the use of the limited amount of mountain range to those enterprises on the more extensive areas of grassland which have nothing but shallow soils.

Sheep raising is carried on primarily for the lamb and wool crops. Lambing starts in the latter part of December and continues to the latter part of February or the first of March. Lambs are sold from June to September.

Relation of Size and Type of Livestock Enterprise to the Character of the Land.--Sizes of livestock enterprises, intensity of production, and farm income have been influenced by local conditions of soil, topography, and climate. Types of livestock farming, defined in terms of the kinds of animals and products produced, have not been so sensitive to differences in the character of the land, although there are small areas where there is indication of some influence of soil conditions upon the type of livestock enterprises. For example, on the granitic soils in the vicinity of Coloma and again near Aukum and Fairplay, the location of which may be seen in figure 2 on page 8 , the proportion of the land devoted to sheep production is much greater than in those areas having heavier soils.

The most obvious of the influences of character of land is its effect upon the size of the enterprise measured in terms of the numbers of animals, and upon the intensity of land utilization. This can be observed 
more clearly by considering the Georgetown Ridge, southwestern El Dorado County, and the lands of the Cosumnes River Basin separately.

1. The Georgetown Ridge: On the Georgetown Ridge more than 40 per cent of the land is rough and mountainous. Much of the remainder is land having small areas of deep soils interspersed among more extensive areas of shallow or stony soils. The more extensive areas of deep soils have for the most part a rolling topography. Sixty-five per cent of the area is covered by timber and brush. As a result many small livestock enterprises are scattered through the woods among the hills. More than half of these keep less than 50 animals. They constitute a supplementary means of subsistence along with other agricultural and nonagricultural enterprises.

About 6 per cent of this part of the county is used primarily for rural residential purposes. Holdings so classified may support 1 or 2 milk cows, 2 or 3 dozen chickens, and a few fruit trees, but only a slight amount of the gross income needed for farm operation and living expenses is derived from the farm. In addition to these holdings used only for residence is the much larger area supporting a similar type of living, the utilization of which is also primarily for residence but somewhat more nearly on an agriculturally self-sustaining scale. People on these "residential" places include those who have an income from some investment or who receive a pension of some kind, or those who work on county roads and for neighbors during the busier seasons, while some depend upon returns from mining. They are situated where some local advantage not pertaining to the area as a whole has attracted them, such as a spring, a small accumulation of fertile soil not too rough for cultivation, a mine, or a deserted cabin. In addition to these, their small supplementary source of income and the attractive advantages of living in the Sierra foothills keep them there. They are for the most part unaware of the public expense required to maintain them in their secluded homes.

Only in a very few places on the Georgetown Ridge have larger-scale enterprises been established. In 1931 four stockmen had more than 250 head of cattle. Two ranches kept more than 200 head of sheep, and each of these had more than 1,000 head.

2. Southwestern El Dorado County: In the southwestern portion of the county there are three general conditions of soil and topography which have influenced the type of livestock enterprise. Extensive areas of the lands in this section have a large amount of shallow soil but have a very small amount of deep soil. Other lands of considerable area, although less in extent, have a predominating amount of shallow soils, but also have interspersed among the other types a substantial amount of deep and relatively fertile soils. In addition to these lands is a third type 
in which rough topography and serpentine ridges predominate. This kind of land is poor, but is not extensive and is relatively unimportant as far as livestock production is concerned.

On lands of the first type, mainly of shallow soils but with small areas of deep soil, relatively large livestock enterprises have been established. Because these lands are the most extensive, the relatively large-scale enterprise predominates in southwestern El Dorado County. Even here the ranch having a herd of 300 stock cattle or a band of 2,000 sheep may be considered a large-scale ranch and typical in size. On lands of the second type, having a more substantial proportion of deep soils, in part because of the greater amount of land suitable for crops, there are a number of instances where small-scale diversified farms have been established and maintained. While many of these are operated primarily to provide the necessities of life for the operators and their families, there is a tendency towards a more commercial type of farming and less dependence upon outside sources of income than in the northwestern part of the county on the Georgetown Ridge.

In that portion of southwestern El Dorado County where there are extensive areas of shallow soils, nearly 60 per cent of the total land area is used in connection with mountain range. In adjoining areas where deep and fairly fertile soils are interspersed among the strictly grazing types, about 20 per cent of the area is supplemented by mountain range. Of the entire area below the National Forest 30 per cent is supplemented by mountain range. The small herd of less than 150 stock cattle or 1,000 sheep cannot be taken to the mountains without excessive cost per head. On farms having a substantial area of deeper soils interspersed with a larger area of shallow soils, feed crops can be produced which make it economical to maintain a smaller livestock enterprise than is required to make use of mountain range. On the other hand, on the extensive area of shallow soils the medium and large-scale enterprises are compelled to depend upon mountain range for summer feed.

3. The Cosumnes River Basin: South of the central portion of El Dorado County is an area lying just below the National Forest boundary, in the basin of the Cosumnes River, where the competition between forest and farm is more in evidence than in most of the other parts of the county. Here crop-land area gains or loses in extent with alternating periods of agricultural prosperity and depression. The soils, which respond very well to irrigation and which during periods of abundant rainfall produce excellent hay and pasture, are inclined to be droughty when water is deficient. During the recent period of declining rainfall, grazing capacities have been low. Beef and sheep enterprises are the dominant type, while very few make use of mountain pasture. The 
ranches oceupying this part of the county, however, are small enterprises. The flock of 200 sheep or herd of 20 stock cattle is frequent. They are so small that it is not economical to rent range in the mountains, assuming that suitable range were available. It must be remembered that all of the best ranges in the mountains have been utilized for many years. A few years of drought places many of the small-scale operators in a very bad situation, and they are compelled under present systems of farming to go long distances for their feed. The problem with these small-scale operators in both the sheep and the cattle business will always be that of securing supplementary feed to tide over the dry season. The farms which still remained in operation in 1931 were maintained, for the most part, by income from outside employment.

\section{COSTS AND RETURNS FROM LIVESTOCK FARMING}

Income is probably the most important determinant of the economic limits of agricultural use of land. At a later point other factors which may determine the feasibility of land utilization for livestock production are considered. It is pertinent here to raise the question whether the prospective incomes from the operation of livestock farms in different parts of the county are likely to be sufficient to make possible the continued utilization of the lands for livestock production under present or improved systems and types of farming.

When supplemented by certain other facts to be presented later, conclusions can be reached regarding the probable future economic position of a large area in southwestern EI Dorado County by considering costs and returns involved in the operation of relatively large-scale, all-grazing, dairy, beef, and sheep enterprises. The economic status of the remainder of the land area in the southwestern part of the county can be determined on the basis of net returns to be expected from the operation of the diversified livestock farm. In order to come to a decision, however, in regard to the extensive areas in which the scattered small-scale farming enterprises predominate, not only are individual costs and returns from the farms and from outside sources involved, but also public expenditures and benefits become an important question.

Beef Production.-The number of pounds of beef produced per ace depends upon the carrying capacity, the number of animals grazed for each 1,000 pounds of beef produced, and the system of ranching which has supplementary feed as a factor. Almost invariably the small-scale rancher, in comparison with the medium and large-scale rancher, carries a relatively larger number of livestock in proportion to the amount of beef produced. The number of calves in the small herd in proportion to the number of cows is usually small and mortality rates are high. 
There is little consistency in the results obtained on the small livestock farm. For example, on one of these small farms which was observed there was a production of 1,000 pounds of beef to 14 animals grazed. Fully twice as many animals per 1,000 pounds of beef produced was the rule on these small-scale ranches as on the large ranches. On the other hand, the larger herds compared more consistently with each other. Herds of

TABLE 10

Annual Costs per Head in 1930 of Maintaining Beef Cattle in El Dorado County on an Ali-Grazing Basis, Exclusive of Interest on Invested Capital and Returns to Management

\begin{tabular}{|c|c|}
\hline Cost items & Cost per head* \\
\hline Taxes on livestock ................ & $\begin{array}{c}\text { dollars } \\
0.57\end{array}$ \\
\hline Taxes on improvements. & 0.09 \\
\hline 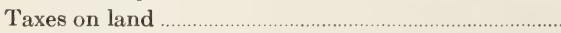 & 2.84 \\
\hline Labor & 5.91 \\
\hline Truck and automobile depreciation and operation... & 1.97 \\
\hline Commissions ……ㄴ.. & 0.47 \\
\hline 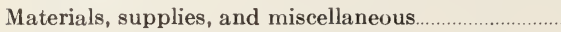 & 1.28 \\
\hline Rent for supplementary range...................................... & 0.76 \\
\hline 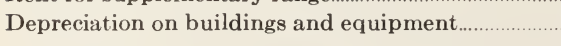 & 0.59 \\
\hline Total... & 14.48 \\
\hline
\end{tabular}

* The costs given above are composite figures taken from several of the large ranches. Although these items cover the cost of raising the calves, the latter are not included in the numbers of livestock constituting the basis of these calculations. These are costs per animal figured on the basis of numbers of yearlings and older stock. The average composition in April, 1931, of the few selected typical herds used in making this estimate was as follows:

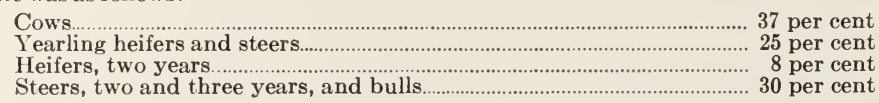

There were about 75 calves to each 100 cows. This does not represent the full calf crop, however.

more than 100 cattle were found to produce 1,000 pounds of beef for each 3.0 to 3.5 animals grazed, excluding stock less than one year old. At this rate the ranch in southwestern El Dorado County having a carrying capacity of 12 acres per cow produces annually, if supplemented by four months' mountain grazing, from 24 to 28 pounds of beef per acre. In the localities having a carrying capacity of 25 acres to the animal on the basis of an eight-months' grazing season, the production per acre is less than half this amount.

Cost of production includes estimates of interest, depreciation, mortality, taxes, and insurance on the herd. It also includes estimated annual costs for maintaining corrals and equipment. Operating costs usually include labor that is hired and the labor and management of the operator. The value of the use of horses, trucks, and automobiles is also considered. The feed item usually constitutes nearly half of the total 
cost. ${ }^{12}$ In the case of the all-grazing enterprise, feed is supplied largely by grass, and its value is determined by the returns from the operation of the ranch.

Table 10 gives an estimate of 1930 costs per head of producing beef in southwestern El Dorado County. This estimate, which is based upon random selection of a number of ranches running from 200 to 300 head of cattle, does not include costs of management, interest, or land rent except for summer feed. Table 11 gives an estimate of gross income per acre at different prices per pound for beef and different carrying capacities of land, and also estimates of costs per acre for different carrying capacities.

In 1930, out of every pound of beef sold, stockmen operating allgrazing beef enterprises in southwestern El Dorado County paid 11/3 cents for taxes, 1 cent for hired labor, and 2 cents for summer feed, commissions, materials, supplies, etc. Thus, $4 \frac{1}{3}$ cents were required before the family of the operator could pay the expense of setting its own table or credit anything to its own labor. ${ }^{13}$ Allowing the meager amount of $\$ 900$ a year for family labor adds another $11 / 3$ cents, bringing the requirement up to $5 \% 3$ cents without having made any provision for interest, to say nothing of land rent. Interest and depreciation on herd and equipment inventory, according to 1930 values, would have required another $1 \frac{1}{3}$ cents. Thus, if inventory values were not written off, the 1930 farm price of beef which averaged 7 cents during the months of fall selling would have been entirely offset by costs.

These estimates of costs and returns cannot properly be interpreted without considering them in the light of the economic situation at the time they were made. The man out of debt, by sacrificing interest on his investment, could have survived had prices remained above 6 cents. Few were in this favored position, however. Many had increased their inventories at the high prices of 1928 and 1929 with borrowed capital; others had contracted to rent or buy land at rentals and prices which had been established during the more favorable period when beef had sold above 9 cents a pound live weight. Foreclosures and "frozen" loans were the result of the period of depression that followed. Notwithstanding the fact that at 1930 costs a price above 7 cents was required before land rent could be paid, prices dropped to 5 cents in the fall of 1931 and

12 See Adams, R. L. The results of a survey to determine the cost of producing beef in California. California Agr. Exp. Sta. Cir. 281:1-22. 1924. Also see supplementary

13 The separation of income into its constituent parts such as interest, wages, and rent is a difficult problem. No pretense is made here of doing so. This illustration is merely used to give the reader some idea of the relation of the price of beef to different elements of cost. Because of the many intangibles involved, meticulous aceuracy in estimating wages received by the operator and his family is not warranted. 


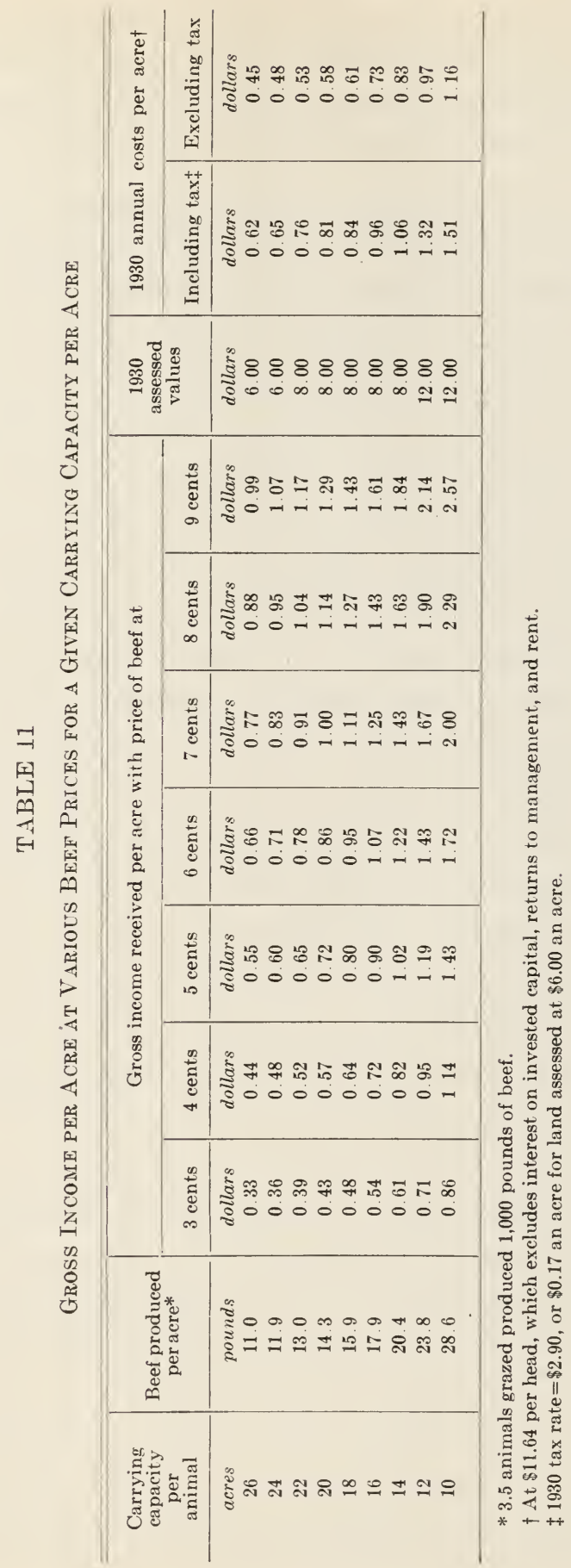


to less than $41 / 2$ cents in the fall of 1932 . It is true that costs declined somewhat also, but costs declined in the two years 1931 and 1932 about 20 per cent, while gross income was cut more than 35 per cent. In comparison with 1928 and 1929, gross income had been eut 50 per cent by 1933.

Such differences in the fluctuations of prices received and prices paid by farmers are characteristic of a period in which the general price level is falling. Ultimately if prices do not rise the fixed charges represented by taxes and investment costs will be forced down by the inability of farmers to pay and a new equilibrium between costs and prices will be established. As disastrous as these adjustments are, they must not be misinterpreted in drawing conclusions concerning the ultimate best use for the land. If prices could be established over a considerable period of time, inventory values would be revised on the basis of new relations of costs and returns, debts gradually would be liquidated, and these open grazing lands of southwestern El Dorado County unadapted to forest would probably remain above the margin of economical use for grazing.

Production of Lambs and Wool.-In 1930 the larger sheep enterprises were getting almost the same gross return for each acre grazed as in the case of the beef producers. The price per pound for lamb was almost identical with that for beef. The drop in prices in 1931 and 1932 was in the same proportion as the drop in beef prices, but the drop in wool prices has been more severe. Producers who had complained in 1930 at having the favorable prices of 1928 cut in half despaired when the 1930 price was again halved in 1932 . The severe losses in inventory values which had already occurred in 1930 , the poor condition of the feed in sheep-producing areas, parasites which had infested some of the herds, and costs of operation remaining at high levels had introduced many distressing but temporary aspects into the situation which must be evaluated and eliminated from estimates of income designed to apply to a long period in the future.

In making estimates of production per acre on sheep ranches the extremely low-producing flocks on the small scattered ranches have been excluded. These scattered small-scale ranches are given special consideration in a later paragraph. Only those enterprises that are making sheep farming their primary business are considered here. The estimates apply to the whole of western El Dorado County.

By observing the changes in inventories of a number of flocks of sheep selected as being typical and by noting the sales and purchases, it is estimated that the equivalent of approximately 80 lambs and 600 pounds of wool are produced each year from a flock of 100 mature sheep, including ewes, rams, and wethers. These rounded figures are very close 
to the averages obtained by combining the results from the several selected herds. Mortality is taken care of in this estimate. Land that will produce 26 pounds of beef to the acre if supplemented four months of the year by mountain range will produce about 1 lamb to 3 acres. In addition to its third of a lamb, each acre will produce approximately $21 / 2$ pounds of wool. At prices prevailing in 1930 the gross returns for each acre of such land would be $\$ 1.80$, which is similar to 1930 gross returns per acre from beef production. At beef prices prevailing in 1930, 26 pounds of beef would bring $\$ 1.82$. In that year the price of 7 cents a pound for beef, used in previous estimates, and of $\$ 4.05$ a lamb and 18 cents a pound for wool were the representative prices.

Notwithstanding the fact that gross returns per acre from sheep were about as great in 1930 as from beef, net returns were much less. Almost every sheep producer from whom information was obtained was operating under some particular handicap. Either extra heavy costs were being paid for privately owned mountain range or excessive prices were being paid for feed and for having it hauled long distances to the ranch. The best estimates that could be obtained averaged from $\$ 3.50$ to $\$ 6.20$ for each mature sheep maintained with the lambs produced, through a year's feeding, exclusive of interest, rent (except for summer feed), and cost of management. In a number of cases mortality rates were very high. These cases were excluded from estimates of gross returns. At the most reasonable figures obtainable, costs per acre included in the winter ranch amounted to $\$ 1.46$, excluding returns for management, rent (except for summer feed), and interest on the investment in livestock or land. It is clear that at these costs, 1930 prices, and systems of operation then prevailing, sheep production cannot continue to prosper in El Dorado County unless as a supplementary enterprise with other types of farming or under greatly improved feeding conditions. There is abundant opportunity for the latter. Long-established sheep industries utilizing the most favored grazing lands and operating on ranches upon which there is no indebtedness will continue in operation.

Costs and Returns on Diversified Farming and Dairy Ranches.Three types of farming previously mentioned (pages 36 to 40) are of sufficient importance to be given some consideration in the analysis of the possibilities of the production of livestock and livestock products in the foothill areas. Examples of each of these types, the combined dairy and beef enterprise, the small diversified farm, and the isolated smallscale, or residence, type of farm follow:

1. The Migratory Dairy and Beef Enterprise : Situated in southwestern El Dorado County is a ranch of nearly 1,800 acres, supplemented by a slightly smaller grazing acreage in the high Sierras, also owned by the 
operator. The income is derived from the sale of beef, cream, whole milk, a few hogs, and a little wood. Production is entirely on the basis of pasture, with the exception of a small amount of hay and barley purchased and a small amount of hay cut from the wild grass. 'The entire dairy is moved to the mountains about June 1. The return is made between October 15 and November 1. The general plan of production is to sell cream to a Sacramento creamery. The cream is shipped daily from the station $1 / 2$ mile from the farm headquarters. The skimmed milk is fed to hogs purchased for fattening and is their only feed. Calves are kept until they are about eight months old and sold in the fall soon after the return from the mountains. The calves and cows which have been culled from the dairy herd, together with a certain number of stock cows kept primarily for beef production, constitute the beef sales. The calves are sold either to local grazers who fatten them and sell them at the end of the grazing season, or to others who may keep them over into their second year. While the dairy herd is in the mountains milk is retailed to campers around Lake Tahoe.

The 1930 income has been estimated as follows :

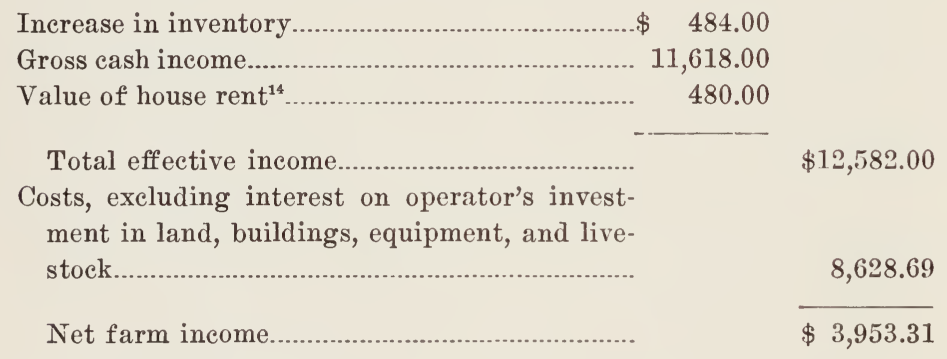

Two residences on the lower ranch and the summer home and bunk house on the upper ranch provide shelter for the family and help.

The net farm income, nearly $\$ 4,000$, represents the returns to the operator for his labor, management, and interest on his net investment of about $\$ 57,000$ in land, buildings, livestock, automobiles, and equipment. About 68 per cent of the gross income represents milk and cream sales, one-fourth of which was cream, the remainder being whole milk. Beef sales represent 29 per cent of the gross income, while sales of hogs and wood make up the rest. Figured on a somewhat arbitrary basis, if this operator could liquidate his assets and earn 5 per cent interest on the investment of the funds thus realized and earn $\$ 1,100$ in wages each

14 It seems most practical for this particular purpose to consider that house rent is one of the products of the farm, rather than to try to separate arbitrarily the items ordinarily charged to the business from those chargeable to the family living, inasmuch as the total investment is more easily considered and more accurately estimated than would be the case if the residences were separated from the total. 
year besides, he could obtain the same cash income. This farmer and his family, however, enjoy their summer in the mountains and their winter in the valley. It is doubtful if they are seeking a change in their way of living.

The experience of this farmer represents one of a number of cases where a rancher with a prior right to a choice bit of mountain range, an early start in a growing milk trade among the summer campers, and business ability, has been able to make real progress in the extreme western part of the county.

2. The Small Diversified Farm : A farmer with a small acreage of alfalfa, about 66 acres of dry-farmed feed crops on fairly deep soil, and about 178 acres of rolling pasture land at an elevation of 1,200 feet had a net income for the year ending April 1, 1931, as follows :

Total effective income

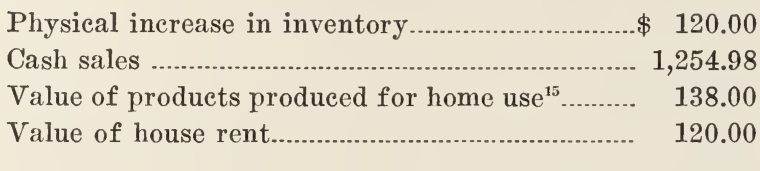

Total $\$ 1,632.98$

Total expenditures

451.64

Net farm income.

$\$ 1,181.34$

Income from outside sources (team labor on another ranch)

50.00

Net income

$\$ 1,231.34$

The cash sales included about equal values in cream and livestock. His hogs were purchased, fattened, and sold in the same year. Other livestock sold were all young stock. From 50 walnut trees he received $\$ 150$; the year before these trees had brought in $\$ 250$. On this farm the annual cropping program included a rotation alternating Egyptian corn and grain hay. The land was plowed in March, each day's plowing being pulverized before new land was plowed. Egyptian corn was sowed about April 25, and about July 1, when the corn was 2 feet high, the cattle were turned in. The barley was allowed to ripen and was fed to the hogs in the straw. This and the skimmed milk from the dairy constituted the only feed given to the hogs. Alfalfa grown upon $1 \frac{1}{2}$ acres of irrigated land yielded approximately 6 tons of alfalfa hay per year.

15 One hog, $\$ 15.00 ; 208$ pounds butter, $\$ 83.00$; fruit and vegetables, $\$ 40.00$. 
The success of this farmer rests primarily on his low operating costs, a statement of which is given below :

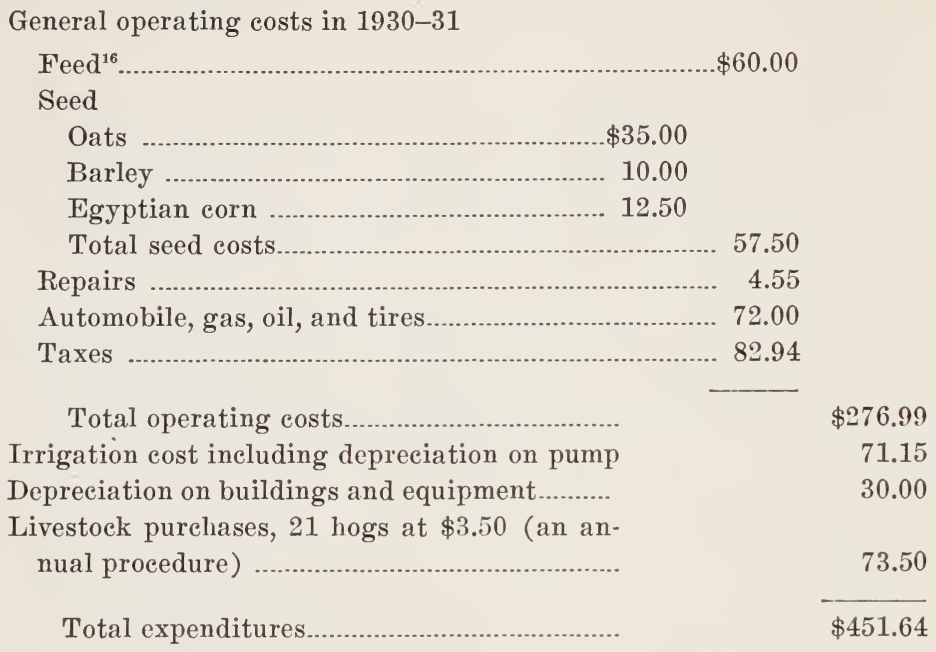

This farm is located on the type of land in southwestern El Dorado County having combinations of deep and shallow soil types and represents the possibilities of the area rather than the present typical utilization. The emphasis on another farm might be on beef instead of dairy, while sheep might be the dominant industry on still another.

3. The Isolated Small-Scale, or Residence, Type of Farm : As grazing capacities become less and less the poorer land is left standing idle by the owners, who usually pay the taxes from other sources of income. The adjacent small-scale operator obtains the pasturage for a nominal sum or for nothing. By occasionally killing a steer, keeping a few chickens, a cow, a few pigs, and a garden watered by a spring, the little enterprise continues to provide existence rations for the operator and his family and a sufficient cash income to meet current expenses. The actual costs of operation of such a farm are obscured by the merging of business and family interests.

On one such farm, operated on the basis of a little higher plane of living than many obtained in 1930 , a gross income of $\$ 340$ was received from the sale of a few beef cows, a calf for veal, a small amount of poultry and eggs, a few pounds of wool, and 400 boxes of pears. This was supplemented by an income of $\$ 650$ from outside work. The costs of operating the enterprise amounted to more than $\$ 700$. It is difficult, however, to separate some of these costs from the costs of maintaining the place as a residence. This case illustrates a prevailing condition.

16 Rolled barley fed in January, February, and Mareh. 
Detailed information obtained for a number of such enterprises, concerning not only costs and income, but also the general attitude of such operators and their families towards their work and their living conditions, leads to the general conclusion that from the standpoint of the individual there is a definite need for providing opportunities for the type of people who enjoy this way of living. From the standpoint of the state and county, however, the present method of providing the opportunity of carrying on this type of existence is too costly. (See pages 68-72.)

Before conclusions can be drawn concerning the probabilities of success on different types of land and before suggestions can be made for improvement, it is important to consider opportunities for supplementing farm income from outside sources, and public costs and benefits.

\section{FOREST-CROP POSSIBILITIES}

The subject of forest crops cannot here be treated historically and descriptively, as the agriculture of El Dorado County has been treated. The forest crop is a long-time crop. Its annual increments cannot be harvested in the year they are produced but must accumulate for many years in any given tree, even when the forest as a whole is managed on a crop-production basis. Moreover, the timber products cut from the forests of the county have not been taken, except on National Forest land, as the harvest of a crop. What men have cut was the accumulated capital of centuries of growth, and it was cut without reference to the conditions necessary to permit the land to produce a new crop.

Forest-crop utilization of land, however, is an important possibility of the future. In the eastern portion of the county the large remaining volume of virgin timber provides the opportunity of so harvesting it as to insure the continuance of forest growth and timber production. In the western portion of the county, as has already been indicated, the practically complete removal of the virgin timber through the last threequarters of a century has been succeeded by second-growth forests over large areas, notwithstanding lack of care of the growing forest, and even efforts to turn the land in the main to other uses. The conditions to which these second-growth forests have been subjected have made them often poorly stocked with trees, having a rate of growth rarely equaling that which the land could produce under proper care. Nevertheless, they already hold a volume of wood which is realized by few people in the county. Even though not yet of commercial value, this growing forest constitutes a fifty to sixty-year start towards commercially valuable timber which should not be sacrificed wherever a careful appraisal shows that the most profitable future use of the land will probably be for timber crops. 


\section{PRODUCTIVITY OF FOREST LANDS IN EASTERN EL DORADO COUNTY}

From a standpoint of growing tree crops, eastern El Dorado County is divided into two distinct units by a line drawn at approximately the 6,000 -foot level. This may be more clearly visualized by referring again to figure 2 on page 8 . In the upper unit the forest consists mainly of the less valuable firs. The possibility that there will be any extensive cutting of timber in this upper belt is very remote. As brought out in the section on recreation, its principal land and forest values are scenic and recreational. The Forest Service has, therefore, dedicated the federal land in this unit to recreational use. Under this policy timber cutting for local recreational or power-development needs, or the cutting of Christmas trees, which has recently increased so rapidly, will be allowed only when so conducted that the primary values of the area are unimpaired. A trend toward similar policies is already evident on private lands.

In the lower unit of eastern El Dorado County, below the 6,000-foot level, most of the land is primarily suitable for growing crops of timber. The total stand is estimated at nearly 8 billion feet, but because of the inaccessibility of some areas and the mixture in others of considerable amounts of the less valuable fir, probably not more than 5 billion feet can be economically logged and manufactured into lumber under any price advance which it seems reasonable to expect. However, this amount of timber is ample to take care of existing sawmills, if their present output of 50 to 60 million feet a year does not greatly increase for the next fifty to seventy-five years, by which time the second growth will be of merchantable size. The fir, as soon as economic conditions permit, will provide a large supply of raw material for a supplementary pulp and paper industry. As previously stated, about half of the timber is government-owned. Government timber is sold under a policy designed to stabilize and prolong the cut of established sawmills and to discourage a greater mill capacity than regrowth can sustain.

An illustration of the application of this policy is afforded by an actual plan of management prepared by the Forest Service for an area of 97,000 acres which extends along both sides of the Lincoln Highway. About 60 per cent of this total timber stand is government-owned. To protect recreational values the plan provides that no government timber will be cut on a strip about a half-mile wide on each side of the South Fork of the American River. To prevent over-cutting elsewhere in this unit it is provided that the government timber will be sold to operators of the private timber, on the basis that the average annual cut on government and private land combined will not exceed 37 million feet. The 
consummation of this plan will result in the old-growth being entirely cut out in sixty-five years. On government land the first cut will remove 80 per cent of the stand, or 22,900 board feet per acre. At the time of the second cut, sixty-five years later, growth ealculations forecast a stand of 24,400 board feet per acre, or 85 per cent of the original.

What will become of the private timber lands when cut over is not yet clear. If conservatively cut they should be profitable to hold for future timber crops. If not, they seem likely to be turned over to the government. Rough calculations indicate that ultimately, under intensive forest management, the combined acreage of government and private timber in eastern El Dorado County can grow two to three times the requirements of the present sawmills in the county.

\section{PRODUCTIVITY OF FOREST LANDS IN WESTERN EL DORADO COUNTY}

To measure the productiveness of land for growing timber where mature timber is lacking, the height attained by the average second-growth trees in fifty years is used. This measure is called the "site index." Thus, the growth capacity of the deforested land of western El Dorado County was ascertained by measurements of hundreds of the scattered secondgrowth trees. The timber-producing capacities thus obtained are believed to be conservative, because the growth of scattered trees and trees on land subject to fire and other unfavorable conditions is less than that which the same land would support in well-stocked stands and suitably protected. The growth capacities are shown in table 12 by site indexes and the corresponding yields per acre in sixty years if fully stocked.

Because of these high growth potentialities and the proximity of the area to wood-product markets in the richest and most populous section of the Sacramento Valley, nearly 300,000 acres out of the total area of approximately 356,000 acres of forest and potential forest land are suitable for timber crops and may be so used when lumber prices make it profitable. This leaves out some 56,000 acres of such land embracing mainly areas now cultivated and over half of the lands now in grass which are also the more favorably situated for grazing use.

That this area can eventually provide an annual lumber cut 1.8 times as great as the present 60 million feet average county cut, and provide a considerable increase in the number of men employed, is indicated in table 17 , on page 93 . Although the full realization of this production is undoubtedly a long way off, substantial beginnings can be made much earlier.

Virgin Timber and Selectively Logged Lands.-No serious forestry problem is presented by the virgin timber and the selectively logged stands in this division of the county, which cover a combined area of 
about 66,000 acres, since they are located mainly within the present limits of National Forest acquisition, that is, in the area outside of the present National Forest boundaries where the Forest Service is authorized by the Raker Act of 1925 to acquire land by exchange. The lower boundary of this outside federal acquisition zone is shown in figure 13 on page 91 . Hence these lands, if not held in private ownership for a second crop, can probably become a part of the National Forest.

TABLE 12

Forest Possibilities of Western El Dorado County*

\begin{tabular}{|c|c|c|c|c|c|c|c|c|}
\hline \multirow{3}{*}{$\begin{array}{c}\text { Site } \\
\text { indext }\end{array}$} & \multirow{3}{*}{$\begin{array}{l}\text { Yield } \\
\text { per acre } \\
\text { in sixty } \\
\text { years }\end{array}$} & \multirow{3}{*}{$\begin{array}{l}\text { Virgin } \\
\text { timber }\end{array}$} & \multicolumn{4}{|c|}{ Restocked cut-over $\ddagger$} & \multirow{3}{*}{ Deforested } & \multirow{3}{*}{$\begin{array}{c}\text { Total } \\
\text { forest land }\end{array}$} \\
\hline & & & \multicolumn{3}{|c|}{ Clear-cut } & \multirow{2}{*}{$\begin{array}{l}\text { Selec- } \\
\text { tively } \\
\text { cut }\end{array}$} & & \\
\hline & & & $\begin{array}{l}\text { Poorly } \\
\text { stocked }\end{array}$ & $\begin{array}{l}\text { Medium } \\
\text { stocked }\end{array}$ & $\begin{array}{c}\text { Well } \\
\text { stocked }\end{array}$ & & & \\
\hline 50 & $\begin{array}{c}\text { board feet } \| \\
14,000\end{array}$ & per cent & $\begin{array}{c}\text { per cent } \\
3.8\end{array}$ & $\begin{array}{c}\text { per cent } \\
4.4\end{array}$ & $\begin{array}{c}\text { per cent } \\
0.7\end{array}$ & percent & $\begin{array}{c}\text { per cent } \\
22.7\end{array}$ & $\begin{array}{c}\text { per cent } \\
11.6\end{array}$ \\
\hline 60 & 21,000 & 22.0 & 52.8 & 22.1 & 14.5 & 18.0 & 52.6 & 37.3 \\
\hline 70 & 32,000 & 56.2 & 23.7 & 40.9 & 55.9 & 49.1 & 20.8 & 33.9 \\
\hline 80 & 46,000 & 19.4 & 17.7 & 21.9 & 20.9 & 30.4 & 3.4 & 13.5 \\
\hline 90 & 63,000 & 2.4 & 2.0 & 10.7 & 8.0 & 2.5 & 0.5 & 3.7 \\
\hline $\begin{array}{l}\text { Total per } \\
\text { cent................ }\end{array}$ & ….......... & 100.0 & 100.0 & 100.0 & 100.0 & 100.0 & 100.0 & 100.0 \\
\hline Total acreage & ................ & 38,520 & 26,193 & 72,803 & 28,722 & 27,559 & 162,044 & 355,841 \\
\hline
\end{tabular}

* Exclusive of National Forest land.

$\dagger$ Site index, or the height in feet attained by the average second-growth trees at fifty years of age, is the measure of the productiveness of land for growing timber. The yield corresponding to site index is that obtainable if the area is 70 per cent stocked.

$¥$ In poorly, medium, and well-stocked areas, respectively, 11 to 40,40 to 70 , and over 70 per cent of the ground space is utilized by regrowth of the commercial timber trees.

\|I By the International Rule, 1/4-inch kerf. Tops utilized to a diameter of 4 inches inside bark. (See table 18.)

I Quantity insignificant.

The Sixty-Year-Old Second-Growth Timber.-Forest practice for the remaining lands should obviously begin with the area now supporting variously stocked stands of sixty-year-old second growth. These stands, aggregating about $13 / 4$ billion feet, board measure, although unmarketable and apparently of negligible value today, represent a potential source of wealth that cannot be neglected. In many localities where the old growth has already disappeared, such timber has even now a value on the stump, in normal times, of $\$ 5.00$ a thousand board feet, or more. ${ }^{17}$ It cannot be predicted just when a value of this kind will materialize in El Dorado County. However, some idea of possible future returns from

17 In 1929 second-growth northern white and Norway pine sold for $\$ 7.64$ per thousand feet board measure in Massachusetts, and for $\$ 14.83$ in Michigan. See: Steer, Henry B. Stumpage and log prices for the calendar year 1929. U. S. Dept. Agr. Statis. Bul. 36:13. Table 3. 1931 . 
forest management may be gained by a consideration of the following example, in which it is assumed that these El Dorado County stands will have a stumpage value of at least $\$ 5.00$ per thousand board feet sixty years hence, when old-growth supplies in this locality are nearing depletion. Though no more than half-stocked now, these stands, under adequate care and protection from fire, should increase about 2.4 times in volume, or to approximately 4 billion board feet, having an end value in 1992 of about $\$ 20,000,000$.

As shown in table 16, on page 92, this represents an average present investment value of approximately $\$ 8.00$ an acre, which means that the increase in timber value in sixty years will be sufficient to earn 4 per cent on a present investment of $\$ 8.00$ an acre for land and timber, besides repaying annual outlays of $\$ 0.40$ an acre for carrying charges, together with 4 per cent interest on these annual payments. These annual expenditures per acre include $\$ 0.17$ for taxes, ${ }^{18}$ and allowances for protection and administration in accordance with the most recent appraisal ${ }^{19}$ of the amounts necessary for sustained timber-land productivity, namely $\$ 0.08$ for fire protection (about twice what is now spent in the best-protected National Forest areas), and $\$ 0.15$ for administration.

While for simplicity it has been assumed in this example that no cutting of timber will take place until 1992, the validity of the example does not require that this be the case. Actually second-growth should begin to find a market much earlier and, as time goes on, should be sold in ever increasing amounts as prices for old-growth lumber advance. Such increased use value can be expected as the more accessible and cheaply logged old-growth stands in El Dorado County and elsewhere in the western states are cut out. Obviously, unrestrained advance cutting could wreck the stand and its ultimate value. With eutting judiciously guided by the growth needs of the forest and towards the highest sustained returns from the area, however, the prospect of earlier income makes these theoretical calculations the more conservative in their indi-

18 This is approximately the present return to the county on lands of this kind (see table 11). Current thought with respect to forest-land taxation is in a state of flux and it is impossible to predict what the future will be. Facts shown on page $42 \mathrm{ff}$. suggest that the present valuation of these lands is much too high in relation to grazing returns; and direct forest returns from these immature stands are negligible. In view of this fact and of the present trend toward reduction of taxation on land, together with the possibility of a larger use in the future of laws already providing tax exemption or reduction for immature timber, it seems probable that the average taxation rate for these El Dorado County secondgrowth lands, up to cutting maturity, will be materially below the present rate, so that even a severance tax at the time of cutting, if such should be imposed, will not make the total of taxes against these timber lands exceed materially that shown in the example on the basis of continuance of the present rate.

19 U. S. Forest Service. A national plan for American forestry. Seventy-third Congress first session, Senate Document 12, p. 1307. Washington. Government Printing Office. 1933. 
cation that the management of these lands for timber crops should provide a profitable and self-liquidating investment. Especially would this be true for a form of public or coöperative private ownership that can borrow money at low rates of interest.

Of this second-growth land, which is indicated by its timber site indexes to have forest-growth capacities averaging those used in the above illustration, there is an area of approximately 126,000 acres, now used chiefly for grazing. This land is mainly in the eastern and northern portions of the western division of the county, where grazing values are generally lower than in the southwestern portion. For the cases studied in the agricultural phases of this investigation, grazing-land rentals in this eastern and northern portion averaged slightly under $\$ 0.20$ an acre.

Deducting from this rental the one item of current taxes, at $\$ 0.17$ an acre, would leave only $\$ 0.03$ an acre for administration, interest on the investment, and profit. It is therefore evident that, on the basis of a grazing rental of $\$ 0.20$ an acre, this land has no investment value for grazing, on any bookkeeping which takes proper account of all the charges against the land.

Can the livestock grazer pay more rental? From the discussion on page 42 it is clear that the livestock producers (as distinguished from the owners of the land), under present conditions cannot, with any remaining profit, pay even the present $\$ 0.20$ an acre land rental, which amounts to $1 \frac{1}{4}$ cents per pound ${ }^{20}$ of beef produced. Nor does any apparently probable increase in the prices of livestock products seem to offer a prospect of the stock industry's being able to absorb the much larger rental which would be required, on the basis of present land values, to increase the forage production per acre of such land as this and permanently sustain it at its potential optimum. ${ }^{21}$

This impasse, in which neither landowner nor livestock grazer is able to make a profit on terms at which the other can do so, indicates grave

20 This is on the basis of table 11, as stated in the footnotes, using 18 acres per animal as a fair average carrying capacity for the land here in question.

21 It is estimated by officers of the U. S. Forest Service that the increased forage yield to be expected from improved management of this kind of land will be not more than one-third. On the basis of the present average rental of $\$ 0.20$ an acre, such an increase would mean an annual rental of $\$ 0.27$ an acre. That this would still be inadequate for any profit from the land will be seen from the fact that, in addition to the tax rate, now about $\$ 0.17$ an acre, the attainment and maintenance of the potential yield are estimated to require annual costs for fire protection as complete as that for forest crop, or $\$ 0.08$ an acre, and administration expenses at least one-third as much as for forest crop, or $\$ 0.05$ an acre. This would make a total annual charge of $\$ 0.30$ an acre, which would be $\$ 0.03$ more than the increased rental. Moreover, this second-growtl land could not be improved so as to give and maintain the best forage production of which it is capable without additional capital expenditures, in land-clearing and in the development of watering, salting, and other facilities, so large that it is not believed they could be returned by livestock grazing use. 
doubt whether livestock grazing will be a profitable use for much of the land here under discussion, at least without the drastic reduction of inventories suggested in the discussion on page 42 . In this reduction of inventories, the facts above presented seem to indicate the necessity of including grazing-land values, the present unduly high level of which, from the standpoint of grazing profit, has been influenced by a speculative presumption of potential value for pear production much more widely than such potentiality warrants.

The facts available seem, therefore, to indicate for the bulk of these western El Dorado County forest second-growth lands an expectation of a higher future value in forest-crop production, under intelligent management, than in a continuance of their present use for grazing.

In weighing forest and grazing values it should also be noted that forest use need not exclude some grazing use of, and return from, the same land. The denser a forest stand is, the smaller may be its grazing value, in general; but with efficient management of the land from the standpoint of both uses, it is doubtful if its feasible grazing use need at any time be of less value than is being realized from it in its present uncaredfor condition.

There is a growing national sentiment for public acquisition and management of forest lands of this kind. In the event that such a program is instituted in El Dorado County as well as elsewhere in California, lands supporting sixty-year-old second-growth trees will be more salable and at a better price than deforested areas. Prospective 1992 values will thus be translated into distinct financial benefits to the present owners.

Deforested Land.-What are the possibilities of forest use of the deforested land, particularly that half of it which is of little grazing value because of dense woodland and chaparral cover? This dense vegetation makes it difficult and expensive to reëstablish forests by planting. Experimental work is needed to develop cheaper and more effective methods. by which it can be done successfully and economically. Even when such methods have been developed, because of the long-time investment involved, any reforestation program will be likely to be a public enterprise preceded by public acquisition of the land.

For some of these lands there is a possibility that clearing or otherwise improving them for grazing would be more profitable than reforestation. Past attempts to do so by burning, while sometimes successful, have resulted on the whole in impoverished soil and a greater area and denser stand of chaparral or woodland. Therefore, burning and other means of clearing on a large scale are not advisable until a sound basis has been carefully worked out for recognizing the specific types of land which can be improved and for applying the proper methods. Without such a 
basis the money spent on any large-scale clearing may not be justified by the results obtained. The answer to the question whether land of this kind should be managed for timber or forage crops or a combination of both can only be given properly by results of unbiased investigation.

\section{RELATION OF THE MANUFACTURING INDUSTRIES TO LAND UTILIZATION}

Although manufacturing industries do not generally occupy extensive land areas, they have an important bearing on land utilization. They provide a consuming population and therefore home markets for the products of agriculture and other industries. The employment of labor in the manufacturing industries and the creation of taxable wealth help greatly to support roads, schools, and other necessary community services which a small agricultural population is often unable to maintain.

\section{THE LUMBERING INDUSTRIES}

In 1932 there were in the county about fourteen sawmills, of which, however, only two are of moderately large size. These two mills have produced the bulk of the county lumber production. The total lumber cut of the county during the five-year period from 1926 to 1930 varied from 52 million to 75 million feet a year, the average being about 60 million feet. Such a production had an average mill value for those years of about $\$ 1,500,000$. One of these, located at Diamond Springs, has not operated from 1931 to the time of the preparation of this bulletin.

The assessed valuation of the lumber operations in the county in 1931 was about $\$ 1,400,000$, and of the taxable timber of the county about $\$ 2,160,000$, or a total of $\$ 3,560,000$. This represents 34 per cent of the total assessed valuation of the county in that year.

Besides the private timberland and lumber operations which pay tax returns to the county, the large area of National Forest land is viewed by many local people as one that is being unfairly withheld from making its proper contribution to county revenues, because it does not pay taxes as such. But the federal government for many years past has contributed to local governments 35 per cent of all federal revenues from National Forest land in each state, either through money (25 per cent of receipts) returned directly to the counties containing such land, or through money (10 per cent of receipts) spent by the government within these areas for roads, the cost of which would otherwise fall upon the counties. It is shown on page 109 that at the time of the study the government was returning to the counties of the state for these lands as much revenue as could be expected to be realized from their taxation 
in private ownership, or more. It seems legitimate, therefore, to include the government timber in the county's total revenue-yielding timber resource. That inclusion would raise the county's total timber resource (from which the county is now receiving taxation revenue or its equivalent) to the equivalent of an assessment valuation of approximately $\$ 5,000,000$. Thus viewed, the revenue-rielding timber asset is the largest single class of property in the county and amounts in value to nearly three-fourths as much as all the rest of the present assessable county values. If those present second-growth areas of the western portion of the county, whose probable best future use is indicated by this study to be for forest-crop production, are so used and are adequately managed for sustained productivity, the future timber resource of the county should be much larger than it is at present.

The sawmill industry of the county has employed, for the average production previously stated, about 900 men for an average period of seven months a year, with an annual pay roll of at least $\$ 750,000$. The proportion of this employment that goes to residents of the county has averaged about 87 per cent, which is considerably higher than has been true of some other counties. The lumber industry in this county has thus made a very considerable contribution to the seasonal maintenance of those engaged in agriculture whose farms do not entirely support them. That this contribution can be made a helpful element in the attainment of a more stable economic condition for the county is further indicated on page 86.

Virgin-Timber Asset.- The virgin forests of the eastern portion of the county are adequate, with proper management, to supply the lumber output of the county until the second-growth forests are marketable. This large, old-growth pine timber is peculiarly adapted to specialty uses, into which it predominantly goes. For example, the greater size to which ponderosa pine grows in California than in other parts of its wide range, produces timber having larger and fewer knots. A larger proportion of the tree can therefore be cut into the more valuable "clear" and "shop" grades, demanded for such products as cabinets, finish, and sash and doors, while less is left in the cheaper common grades. The sugar pine, which is mainly a California tree, is of even higher quality and larger size than the ponderosa pine. The bulk of such superior specialty grades goes to the heavier population centers of the East and will be increasingly in demand there as the available supply decreases in the country at large.

The Douglas fir of the California Sierra Nevada region now lacks an adequate market because of the supplies from the Pacific Northwest at prices below those at which the California product can be sold. This 
discrimination should tend to disappear with the probable remedying of distress conditions in the latter region. The California fir, also, while not so strong as that from the northwestern coast for heavy building construction, is on the average softer and more easily worked, and thus preferable for the specialty uses into which our pines largely go. As the supplies of high-grade pine diminish, therefore, an increasing market and value should develop for California Douglas fir in these uses.

The incense cedar is a tree whose wood has the general characteristies of cedar woods, including long life against decay, and a very distinctive aromatic odor. Its chief present market is for pencil slats. This market has kept its price relatively nearer that of normal times during the present depression than was true of the lumber of almost any other common soft wood. The wood suffers heavy waste in cutting into lumber because of the prevalence of "pocket rot" in the older trees, but should find profitable additional uses in the future for closet lining and similar purposes.

The true fir species, including in El Dorado County white fir and the true red fir (not Douglas fir, which is sometimes called red fir), although of lesser value than the pines for lumber, are so excellently adapted to pulp and paper manufacture as to represent an important future asset because of their large volume within the timber belt of the county. When the utilization of these fir species for pulp can begin in El Dorado County it would not be safe to predict, but the whole trend of the nation, except during the depression period, has been towards constantly greater paper and pulp consumption.

Second-Growth Timber Asset.-It has been stated (page 53) that if the areas of the western half of the county, which have been shown in this report to be potential forest land, are devoted to timber growing, the $13 / 4$ billion feet of timber already present on these lands indicate that when their present understocking is brought up by proper treatment they can come near to equaling in timber volume the commercially loggable portion of the present virgin-timber belt. Such a development would tend to bring sawmills and wood-working plants next door to the main ranching areas. The development of a diversity of supplementary wood-manufacturing plants, as well as of other enterprises, would be helpful to the prosperity of the county. Such a development seems feasible, if the county is wise enough to conserve the forest resource upon which the development will depend, and to prevent the wastage of that resource either by fire or by destructive exploitation.

Among wood products which might be produced, wood fuel will probably continue to be largely used locally. Douglas fir, on account of its strength, will doubtless continue to be the preferred species for mining 
timbers. Second-growth Douglas fir, as well as pine, will eventually come into use for many purposes for which higher-grade material is now employed. Among sawed products, box shook to supply the fruitpacking industry of the county seems likely to continue in large use. Local production of the shook required in the county would permit profitable use of much low-grade material which is less profitable for shipment to outside markets. Play equipment, kitchen and porch furniture, and the numerous kinds of ingeniously designed household equipment recently increasing in popularity offer manufacturing possibilities in which plants situated close to the lumber supply, and thus able to use "shorts" and other material unsuitable for standard lumber, would have an advantage over distant plants dependent upon the latter. Toy and novelty-making may also present profitable opportunities, such as have been successfully developed in recent years in the second-growth forest regions of New England. Nor should it be impossible, it is believed, to develop profitable products such as wall board from sawmill waste. In the case of wall board, this might be, perhaps, in conjunction with byproducts of the local lime industry. Still other possibilities would doubtless await only the application of ingenuity and resourcefulness.

How the Virgin-Growth and Second-Growth Timber Will Work Together.-At the present rate of timber cutting in El Dorado County it is computed that the commercial virgin timber will last for more than eighty years. An accelerated rate of cutting is generally anticipated on the Pacific Coast because of the steadily decreasing supplies of virgin timber in the eastern United States. If El Dorado County can hold the rate of harvesting of its timber to that which can be replaced by growth, there is ample time for the present second-growth trees to grow to cutting size.

Since the Pacific Coast is the last of the great virgin-timber regions of the United States, the diminishing supply and receding accessibility of its remaining virgin timber, as lumbering proceeds, may be expected progressively to confine the high-grade product of the old timber to luxury users able to pay its higher value. This should result in sending such products, in increasing proportion, to the urban population centers, where there is concentrated the wealth able to command the best and to pay for heavier transportation costs upon it, and will compel the home market, for its common lumber uses, to turn correspondingly earlier to the second-growth supply. This trend should result in preparing a market for second-growth timber well in advance of the readiness of the timber for cutting. The proximity and accessibility of such timber in western El Dorado County, both to local consumers and to the Sacramento region, should give this timber an advantage in the develop- 
ment of such marketability over most other California second-growth timber. In the meantime, well-managed second-growth forests with proper protection, ean and should make other returns justifying their preservation, as is later indicated (page 95).

In summarizing, both the virgin timber of the eastern part of the county and the second-growth of the western part constitute a forest resource of great value to the county. In addition, this resource holds the possibility, if wisely developed, of a collateral service in stabilizing the agriculture of the county and, through it, the county's general economic structure by the supplemental income which it can afford to the farms.

It was said on page 59 that there will be ample time for present second-growth trees to grow to eutting size "if El Dorado County can hold the rate of harvesting of its timber to that which can be replaced by growth." A temporary prosperity, followed by economic and social decay, has been the result of "cut-out-and-get-out" lumbering" without thought to maintenance of the forest, in regions such as the Great Lakes states, where that kind of lumbering has run its course. The maintenance of continued balance between timber cutting and timber growth is the most essential condition of the county timber land's continuing to yield both financial profit to the owner and services to the public, such as watershed protection, through a long-time period. With such a policy of production control, accompanied by the other measures of good forestry practice, El Dorado County should be able to anticipate ultimately a total annual forest crop of some five times as much as the past average annual lumber production of the county's sawmills.

\section{HYDROELECTRIC POWER}

Power plants with more than 30,000-kilowatt capacity are developing the energy of El Dorado County streams. The location of these plants together with potential power resources is shown in figure 11. The ultimate development of the South Fork of the American River in El Dorado County has been estimated by Frank E. Bonner ${ }^{22}$ at 263,000 kilowatt capacity with an average output of 153,699 kilowatts. A portion of the power resources of the North Fork and Middle Fork and of the main river may also be credited to El Dorado County. Bonner has estimated that the future development of these streams will have an ultimate capacity of 273,000 kilowatts with an average output of 163,709 kilowatts. Of the power plants and reservoirs included in these estimates those diverting the waters of the upper Rubicon, and Gerle and

22 Bonner, Frank E. Report to the Federal Power Commission on the water powers of California. p. 103. U. S. Govt. Printing Office. 1928. 
Pilot creeks, developing 22,000 kilowatts, will be entirely within E1 Dorado County. The others are proposed developments on the boundary lines of Placer and Sacramento counties. The branches of the Cosumnes River are not good power streams because their upper tributaries do not reach high enough altitudes.

Power resources exceed the demand for power. The proposed Coloma Reservoir, which is a unit of the state water plan, probably will not be

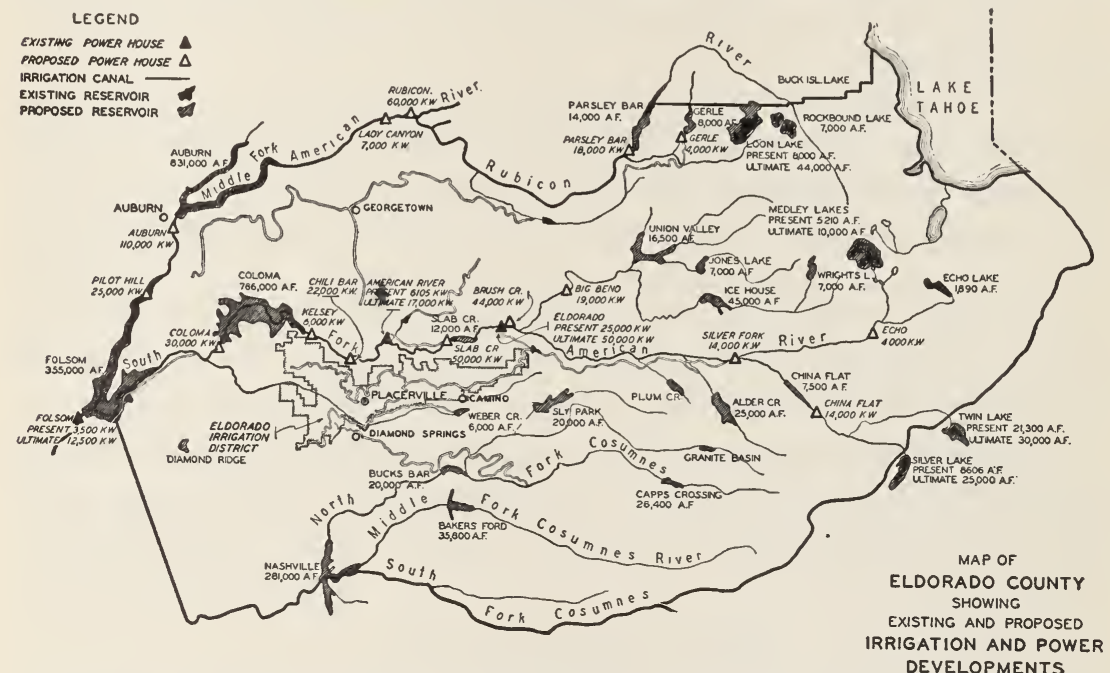

Fig. 11. - The water resources of El Dorado County have been only partially developed.

needed for power and irrigation for a number of years unless the state's decision in favor of constructing the Kennett Dam should be reversed in favor of the American River development. At such time as the Coloma Reservoir is built the historic region about Coloma will take on an attractiveness which, with its convenience of location, will increase the recreational value of the lands in that vicinity. The Pacific Gas and Electric Company does not plan for many years any expansion of its developments in the county other than the rehabilitation of the American River plant in its present or another position, the final location depending upon the proposed projects of the city of Sacramento on Silver Creek.

Under present methods of power generation and distribution, the power resources of El Dorado County are a state and not a local asset. The power from El Dorado County streams is now being sent largely to the urban centers of the Sacramento and San Joaquin valleys and coast. The Silver Creek project would be developed primarily as a source of water supply for the eity of Sacramento, while the power probably 
would be sold at the switchboard to the power companies. Any industries which may be economically established within the region because of local advantages would have, under present rate structures, the same power costs and facilities provided in urban centers. Nearness to power resources gives no corresponding advantage. Revenue received by the county from the power companies through taxation is negligible. Taxable values are created and wealth accumulated at the terminals of the transmission lines beyond the boundaries of the county, not at the powerhouse switchboard.

It would be advantageous to the power systems to increase power consumption near points of generation, and to encourage foothill counties to consume locally as large a part of the power generated by its streams as the other natural resources, labor conditions, and markets will permit. Such use of energy would forward the industrialization needed to strengthen agriculture. Classification of land in the vicinity of Camino, Placerville, and Diamond Springs, looking forward to this industrialization and its benefits to the county, would be justified.

The use of the shores of reservoir sites for recreation would develop an added source of local income, and the demand for land bordering the lakes of the foothill region indicates a possible future recreational advantage in the development of reservoir sites. Recreational use, however, is not always consistent with the primary power and irrigation use, and further development for irrigation or power will not in any case be required in El Dorado County for several decades. In the meantime, recreation business of large volume is developing in the Lake Tahoe region and, as is pointed out elsewhere, is certain to increase to one of the chief assets of the county.

\section{MINES AND MINING}

The influence of the early activities in mining upon land utilization has already been mentioned. It is important to give some further thought to the relation of present and probable future mining operations to the planning of land use. There are two aspects of this question. One of these pertains to the distribution of population in the county. It is considered by those who are in a position to influence state mining policies that it is in the best interests of the state to allow freedom to prospectors in their search for valuable mineral deposits. On the other hand, the vicissitudes of the mining industry account in part for the rise and subsequent decline of the populations of high-cost school districts, the rise and fall of business opportunities in different localities, and the lack of stability of communities. Moreover, the existence of a multitude of 
small parcels of land in mining properties introduces obstacles to programs of land utilization such as have been available to other localities.

The other important aspect of the mining industry in relation to land utilization is the extent to which the mineral resources may be expected to support local industry. Nearly half of the state production of industrial lime is produced in an El Dorado County plant that gives employment to about 60 workers. By-products from this plant offer many promising side lines.

Slate of fine quality was formerly an important commercial product shipped from Placerville, but owing to severe competition of cheaper roofing materials the industry has declined. A considerable amount of ground slate is still produced, however. Local leaders have suggested that this industry probably could be reorganized on a much more extensive basis.

Other important mineral deposits include lead, silica, and soapstone. Gold is still important but instead of being first, as in the early days, El Dorado ranks thirty-first among the counties of the state in gold production. The depression has revived gold-mining activity. It is probable, however, that the exploitation of some of the more common commercial products may lead to a more permanent and substantial industrial development.

\section{FRUIT-PACKING PLANTS}

The fruit-packing plants of Placerville, five in number, provide employment for local and itinerant labor. The variability of this employment and of the cash receipts for fruit has given the local economic activity violent annual fluctuations. Planning of coördinated industrial development in the future may offer some means of giving greater stability to employment and to the total cash receipts of the community.

In summarizing, El Dorado County has many industrial possibilities. The forest industries are and apparently can remain the chief of these if the county fosters, protects, and properly manages the forests upon which they are based. But many other industries, such as mining and related enterprises, can add to the wealth of the county, more completely utilize available raw materials, and contribute by their seasonal supplementary employment to the profitable maintenance of agriculture.

The stabilization of the economic structure of rural communities could be facilitated by the further coöperation of producers of electric power in the local distribution at rates which will make more economical the local development of profitable industrial enterprise. The economic factors governing the location of industries are complex, however, and require further intensive investigation before the selection of new enter- 
prises will be feasible. The most important first step is to protect the natural resources that are vital to existing industries and, in the case of nonrenewable resources, to plan for the time when some of the established plants will have exhausted the raw materials which have made it possible for them to operate.

\section{RECREATION AND ITS RELATION TO LAND USE}

Recreation has been growing rapidly throughout the country and is becoming a factor which cannot be neglected in considering the future assets of El Dorado County. The spectacular rise in recreation has occurred since the World War. The chief factor responsible for it has been the increased use of the automobile, with its accompanying extension of good roads and increased leisure to use them.

This development has been carefully studied by the United States Forest Service and its conclusions are instructive. Before the War the maximum number of visitors per year registering at the national forests of California was approximately 150,000, including transients. In 1916 this number had risen to 707,550 . In 1932, including transient travelers, as before, the total was $17,804,000$. Slightly over 78 per cent of this total were transients not stopping in the forest; but confining the figures to the people who actually used the forest for recreation purposes, the number was $3,610,500$. On either basis this increase will be seen to be vastly greater than the increase in state population during the period involved. It is also worthy of note that recreation has been the only use of the national forests which has continued to increase in spite of the depression.

\section{CAMPING AND SUMMER HOMES}

A recent special study of this phase of recreation development has been made by the Forest Service for the Eldorado National Forest. The exact figures for El Dorado County are not segregated, but since nearly seventenths of the total area of the Eldorado National Forest is included in El Dorado County, the results will have a proportionate application. This study showed that in 1930 there were 683 national-forest permits for summer homes and resort purposes, from which the government's rental receipts for the year were $\$ 11,306.50$. The area actually occupied was only 630 acres. This gives a return of $\$ 18.84$ per acre.

A comparison with the grazing returns from the same forest is instructive. In that year there were about 400,000 acres of used government range land, on which there were grazed 7,269 cattle and 15,547 sheep. From these the grazing fee receipts of the government were 
$\$ 7,320.00$, representing a return per acre grazed of 1.8 cents, as against the recreation return of $\$ 18.84$ per acre. Now it is apparent that the large acreage of government land available for recreation use in the forest can never be completely occupied. To do so, or anywhere near it, would destroy the very qualities desired by the recreation seeker. But it is also evident that the 630 acres occupied in 1930 and centering almost entirely around Lake Tahoe constitute the merest beginning of the possible and probable future development. It is equally clear that recreation as a revenue producer per acre ranks above practically every other ordinary form of wild-land use.

The total value of improvements on the 630 acres occupied under recreation permits in 1930 was $\$ 589,215$; and it is to be remembered that every dollar thus invested by recreationists upon government land is taxable by the county. The extent to which these recreation results have withstood the depression is indicated by the fact that in 1931 the number of permittees increased to 860 , or by 26 per cent, and the government receipts increased to $\$ 14,413$, or practically the same percentage increase over that of the previous year. On a corresponding ratio, the 1931 value of recreation improvements would be $\$ 745,000$.

It should be noted that the figures given above are only for government land. The recreation development on private land around Lake Tahoe is at least as large and probably larger than that on government land and the capital invested in improvements is proportionately much larger because of the greater size and luxuriousness of a large proportion of the private establishments thus erected. In addition, not only do the figures given above represent government land, exclusively, but they do not include on that government land the free public camp grounds maintained by the Forest Service, which are used by at least 60,000 people a year. While these free camp grounds return no revenue to the government but represent only a public-service expenditure, they bring a very considerable revenue to the citizens of the county through the food and other purchases of the campers. Studies of the expenditures of recreationists indicate an average, for rich and poor, of about $\$ 4$ a day. On this basis and an average stay of five days per person similarly arrived at, the estimated total annual expenditure within this region by recreationists would amount to $\$ 1,200,000$.

The whole trend of recreation development, with its constantly accelerating rate in recent years and its unique resistance to the retarding influences of an extraordinary depression, make it appear certain that with the return of prosperity the importance of this use of land will increase even more rapidly. So impressive is this trend that one of the best informed of those most closely in touch with it believes that within 
ten years recreation will bring to the Lake Tahoe region and the tributary high-mountain quarter of the county a higher assessed valuation than that of all the rest of the county put together. Here, then, is an asset to be taken account of and to be fostered in every judicious way for the future prosperity of the county.

The summer residence and camping development of recreation is not likely to be as pronounced in the lower portion of the county as in the upper. However, it must result in stimulation for the towns along main travel routes, especially the town of Placerville. In certain places also where there is water, in addition to forest and other attractive scenic features, as in connection with some of the existing or proposed reservoirs or in localities having areas already provided with irrigation water, recreation or permanent country residences may develop to local importance in this lower portion of the county, if the forest is protected and allowed to return. No recreation seeker is tempted to stop in a brush patch or in a cemetery of burned and blackened tree stumps.

Fish and Game.-A greater possibility for recreation revenue to owners of wild lands in the agricultural portion of the county may lie in the development of the game resources of their lands. It is significant that, of the 67,000 users of the Eldorado National Forest in 1932 who stayed longer than to picnic, nearly 30,000 were hunters and fishermen. Foothill wild lands within agricultural elevations are especially favorable for valley quail and numerous upland game birds. Gray squirrels, rabbits, and other fur bearers may also come into the foothills picture. Deer need foothill range for the winter months and, although troublesome at times, they may be a source of appreciable income to the foothills rancher, notwithstanding their drift toward higher elevations during the summer.

Quail and other game birds of our foothills are progressively disappearing from ever widening areas. This is due not only to increasing kill by an increasing number of hunters, but also to the increasing areas made inhospitable to wild game by the steady encroachments of civilization upon their wild habitat. Such encroachments include the preëmption by livestock of the vegetative food supplies and the removal of the trees and brush necessary for game shelter and concealment, by land clearing, and especially by the fires which are used in attempting to secure grazing betterment.

This situation has been the natural effect of a growing population. Where the wild lands have been converted into productive agricultural lands of much higher value it has been recognized as an inevitable result of progress. The point has been reached, however, where the remaining good game land in foothill areas most accessible to population centers 
is insufficient to produce the game supply which would readily be used, in preference to that of more distant localities, if it were available. There seems to be for such lands a definite prospect of future increasing value. Indeed, where agricultural values are low, it is felt by many careful observers that game production promises to be a more profitable use of land than agriculture in regions easily accessible to population centers. El Dorado County is such a region.

It seems that if there are to be game to hunt and fish to catch, their production must relatively soon be placed under as careful management as that of domestic animals. If, however, artificial production and maintenance of game supplies is undertaken on private lands, some system must obviously be developed through which the necessary time and effort and expense of the landowner can be suitably recompensed, for example, by the payment of hunting or fishing fees by those who enjoy the sport thus provided. Such a development encounters the opposition of the instinctive pioneer feeling that free hunting and fishing are the right of every citizen; but the progressive limitation of this freedom seems to be as inescapable as any other accompaniment of our departure from the pioneer era. The State Division of Fish and Game has been giving much thought to this development and is in a position to advise with landowners who are interested in making a coöperative attempt to develop game farming as a profitable form of land use.

Such a land use will make exacting demands upon the management of the land. Perhaps the first of these is that the land must be in a condition suitable for the stocking of the desired game. It would be futile, for example, to expect quail to thrive and multiply on heavily overgrazed and repeatedly burned lands. Good quail land must have sufficient food for the birds, of which grass seed is an important item, must have accessible water within feasible distance, and sufficient brush or woodland cover for the shelter as well as food requirements of the birds. Most other game birds and animals are more shy than quail and require correspondingly more extensive shelter. Promiscuous burning is the most destructive deterrent to game propagation, killing great numbers of birds and animals, destroying their shelter, and reducing their subsequent food supply. The seed of brush species which tend to predominate following repeated burning also has little value for quail.

Promiscuous burning, severe clearing, and heavy grazing are therefore to be avoided on game lands. Technical knowledge would be required for many questions, such as how far the raising of quail and fur bearers could be combined, the necessary extent of control measures against predators, such as hawks, etc., and policies of hunting restriction when necessary for perpetuation of game supply. 
Game management can easily be combined with that for forestry, although good timber-growing land is not essential to successful game propagation. Certain other combinations may also be practicable, including, within limits, that with grazing. Where extensive burning is deemed necessary for the latter, it may be well to consider carefully which use will be the more profitable and to omit the less profitable one. There appears to be at least a good chance that, in many cases, management of land for game may be more profitable than present uses. Indeed, one noted authority believes that game farming can be made more profitable than any other agricultural use for suitably located lands other than those of the highest fertility.

\section{COUNTY EXPENDITLRES FOR ROADS AND SCHOOLS AS AFFECTED BY LAND UTILIZATION}

Taxation of land has an important effect upon its use. Utilization of the land, on the other hand, has just as important an effect upon taxes. Taxation policy and administration, therefore, may be a useful means of influeneing land utilization. while planned land utilization may be an important element in a constructive program of tax reform.

Inasmuch as a detailed statement of the income and expenditures of the county is published each year, it will be necessary here to refer only to those items which have an important bearing upon land utilization. The expenditures by the county during the year ending .June 30, 1931, are given in table 13 .

\section{COST OF EDUCATION}

It will be observed that 42.6 per cent of the county expenditures shown in table 13 were for education. The state also extended aid to the counties for educational purposes, which, during the year ending June 30, 1931, in El Dorado County amounted to $\$ 49,517.86$ for elementary schools and $\$ 8,920.89$ for the high school.

By action of the voters of the state in .June, 1933, the minimum of $\$ 30$ per child, on the basis of average daily attendance, formerly contributed by the state for primary education was doubled. Similarly a minimum of $\$ 60$ per child in average daily attendance in high schools formerly contributed by counties under the mandatory county school-tax law was added to the state's former contribution of $\$ 30$. It is obvious that with such a subsidy the economic limit of liuman occupation of unproductive areas is greatly extended, as far as local governmental costs are concerned.

Previous mention has been made of the scattered residents and farmers operating on a very small seale. The school laws of the state, which 
are designed to furnish education to all children, include provision for the children of these "part-time farmers," prospectors, homesteaders, and the like. These laws are based upon the justification that every child in the state is entitled to an education. So strong is the support of this idea, that schools have been taken to the child with little thought being given to the possibility that the family of the child might more economically be brought to the school. Of course an attempt has been made in some of

TABLE 13

El Dorado County Expenditures for the Year Ending JUNE 30, 1931

\begin{tabular}{|c|c|c|}
\hline Item & Expenditure & $\begin{array}{l}\text { Proportion } \\
\text { of total }\end{array}$ \\
\hline 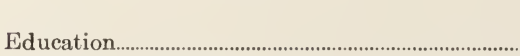 & $\begin{array}{c}\text { dollars } \\
200,696.95\end{array}$ & $\begin{array}{c}\text { per cent } \\
42.60\end{array}$ \\
\hline 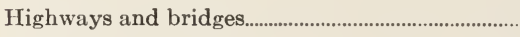 & $91,608.90$ & 19.90 \\
\hline General government & $57,782.32$ & 12.25 \\
\hline 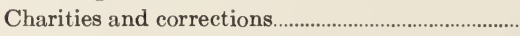 & $65,754.80$ & 13.85 \\
\hline 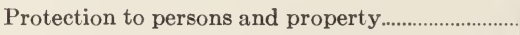 & $20,645.37$ & 4.36 \\
\hline 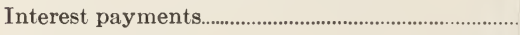 & $13,846.00$ & 2.78 \\
\hline Bond redemption & $11,500.00$ & 2.44 \\
\hline 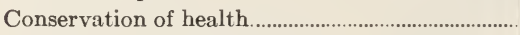 & $2,796.52$ & 0.59 \\
\hline 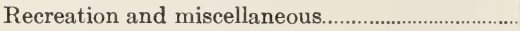 & $4,293.78$ & 0.95 \\
\hline Advertising & $2,246.89$ & 0.48 \\
\hline Total..... & $471,171.53$ & 100.00 \\
\hline
\end{tabular}

Source of data:

Koletzke, Arthur J. El Dorado County financial report for the fiscal year ending June 30, 1931. 59 p. Office of the County Auditor, Placerville, California.

the other counties to solve the problem by the consolidation of schools and the inauguration of bus service. The thought has still remained, however, that if a family continues to live in a remote area it is entitled to public funds for the education of the children regardless of excessive costs. Is it in the public interest to continue this kind of service? It remains the obligation of the state to see that every child has an education. But it is also important to inquire concerning costs of different means by which this may be accomplished.

The character of the land and the consequent sparse population in much of El Dorado County suggests the possibility of important savings in the cost of rural education through adjustments in land utilization. During the school year $1930-31$, there were 1,020 pupils in attendance in El Dorado County primary schools. Of these, 535 attended the five largest schools. Four schools, operated in coöperation with other counties, accommodated 9 pupils of El Dorado County. The remaining 476 pupils were taken care of by forty-two schools, or an average of only 11.3 pupils each. 
In schools having more than 25 pupils the average cost per pupil was $\$ 70$. In one district the attendance of which had dropped to 4 pupils, the annual cost of operation, exclusive of capital outlay for buildings and equipment and the interest thereon, amounted to $\$ 355$ for each

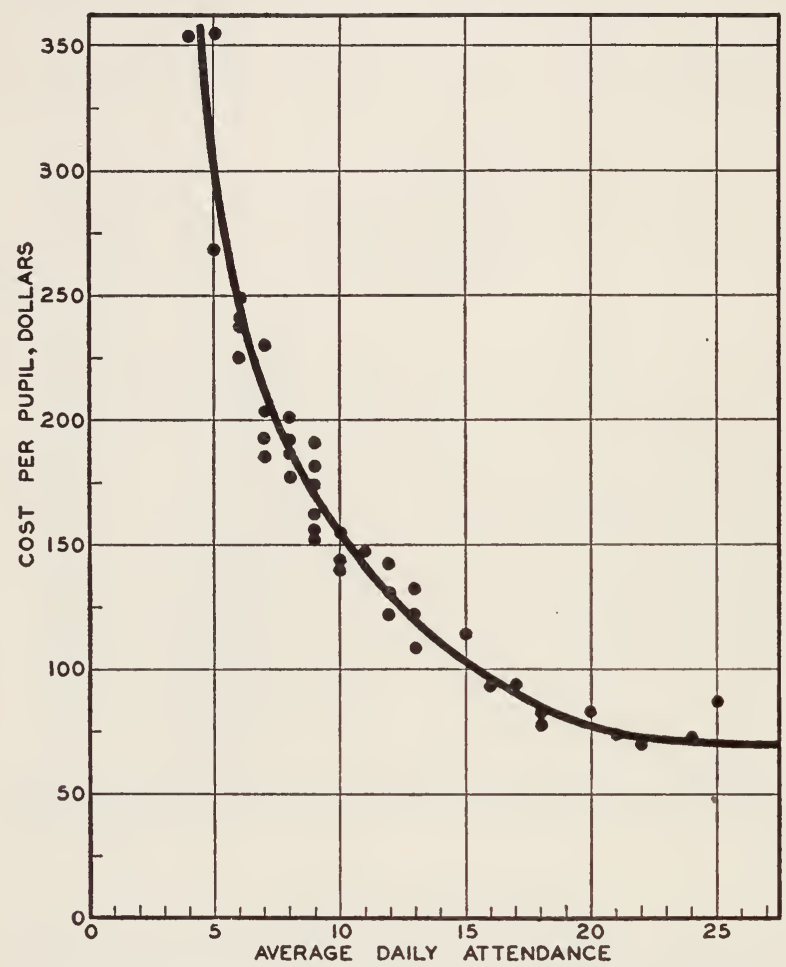

Fig. 12.-Cost of primary education in El Dorado County schools, 1930-31. The cost per pupil, exclusive of capital expenditures for operating El Dorado County schools is shown here. When the average daily attendance drops below 25, the cost per pupil mounts rapidly.

pupil. This school, of course, under the California law could not continue with such low attendance. In ten schools, however, each having an average daily attendance ranging between 5 and 7 , the cost per pupil averaged more than $\$ 233$. In thirteen schools in which the attendance was from 8 to 10 pupils the average cost per child was in excess of $\$ 168$. In fact each of thirty-two of the El Dorado County rural schools operated at an average cost per pupil which was more than 180 per cent of the average cost in schools of the county having more than 25 pupils. Figure 12 shows the relation of attendance to cost per pupil.

After excluding the schools jointly operated with other counties and the five largest primary schools, the annual cost of operation, exclusive 
of capital outlays and interest, for the small schools amounted, in the school year $1930-31$, to $\$ 64,240$ for 476 children, or an average of $\$ 135$ per pupil. If these children had attended schools having 25 or more in attendance the cost per pupil would have been approximately $\$ 70$, a difference of $\$ 65$ per pupil or $\$ 20,940$ for a single year.

A number of these small schools are in the higher, nonagricultural portion of the county. Arrangements with power companies, lumber industries, and other public service agencies might do much towards keeping families with children from having to reside permanently in remote situations where a school must be maintained for 5 or 6 children.

\section{ROAD COSTS}

An important element of the public cost involved in maintaining sparse populations on scattered farms is the construction and maintenance of roads. Of the $\$ 91,608.90$ spent for roads by the county during the year ending June 30, 1931, $\$ 25,901.61$ was from the state motor vehicle fund. In addition, about $\$ 0.65$ of the $\$ 2.90$ county tax rate per $\$ 100$ of assessed valuation went for the maintenance and construction of county roads and for bridge maintenance. The five different road districts in the county receive equal portions of these state funds, regardless of populations to be served.

Investigation has revealed the fact that the incomes derived by residents in these remote areas are frequently in a large degree wages received from the state or county for work on the roads that are provided at public cost to enable them to live there. In many localities work on the roads has been a helpful and legitimate source of income. However, where the maintenance of the population of a rural area is dependent upon the income received by working on the roads which would not be needed except by the people who work on them, there is a question as to the wisdom of continuing the construction and maintenance of such roads. County expenditures for roads are not always allocated in sufficient detail to balance such expenditures against the benefits derived in each case. Furthermore, some county roads constitute means of travel through an area by its residents jointly with those of many other localities. Instances have been observed, however, where country roads could be abandoned advantageously or where future road-building programs could be curtailed if other opportunities could be found for the few residents of the areas served.

It has been seen that the monetary returns per acre from the grazing lands of the county are not great and that much of the land returns very little income because of its character and that of its natural vegetation. Costs of constructing and maintaining county roads through these areas 
vary from 8 to 12 cents an acre for all of the lands included within the different road districts. Such expenditures would be insignificant in cases where the land produced a high return per acre; but throughout areas where the returns per acre are so low, these costs either represent a heavy burden to the owners of the grazing lands through which the roads pass, or they represent, in the aggregate, a burden upon the general taxpayers of the state who are called upon to pay the public cost of continuing an uneconomic situation.

During the fiscal year 1930-31, El Dorado County spent 12 cents for each acre within Road District No. 3 for roads and bridges. Of this amount the county paid 8 cents an acre, while 4 cents came from the motor vehicle fund. Similarly, in the road district comprising a large portion of the Georgetown Ridge the county spent 11 cents per acre for the construction and maintenance of roads, 6 cents of which was supplied from county funds and 5 cents from the state motor vehicle fund. In an area such as the latter one, where grazing-land rentals seldom exceed 25 cents an acre and in which extensive areas do not even return this amount, it can be appreciated that these average costs per acre for road maintenance either pyramid on the lands having higher assessed values or must be paid by funds supplied from outside sources through state taxation.

With respect to both roads and schools the county suffers under disproportionately heavy costs in providing services to the scattered families of sparsely populated areas. And the bad situation tends to be a self-perpetuating one under present conditions. A considerable saving to the county in the cost of these services appears to be possible. Specific suggestions, however, as to how such economies may be effected must be considered in relation to the broader problem of planning the utilization of El Dorado County lands.

\section{WHAT LAND-USE PLANNING INVOLVES}

Before presenting the results of the economic classification of land and the programs of utilization for the different areas within the county it is important to consider again the aims of land-use planning and to view the entire problem in this perspective.

In the fruit-production areas the forced curtailment of fruit-acreage expansion has made necessary a realignment of farm programs which will increase the use of unirrigated portions of the irrigated farms, and of such part of the irrigated covercrop as is consistent with good orchard practice in the production of livestock products for home consumption. These adjustments in the utilization of land on irrigated farms will raise 
questions concerning policies of irrigation development, of refinancing irrigation projects already constructed, and of industrial development, which will require simultaneous consideration with the other parts of the land-planning program.

In parts of the livestock-farming area the character of the land is such that many of the farms could be reorganized for the more economical production and utilization of cultivated and natural livestock feeds. There are also grazing lands that undoubtedly could be improved by the removal of brush as soon as effective and economical methods for such clearing have been developed. There are other areas in which the reduction of grazing from the dominant use to a position subordinate to the production of forest crops as major use would probably, in the long run, result not only in greater returns per acre, but also in important benefits to the communities adjoining such areas. If there were a gradual elimination of the scattered and isolated farms over extensive areas it would undoubtedly be beneficial to the individual landowners and to the public.

\section{AN AGRICULTURAL-DEVELOPMENT POLICY}

Agreement with respect to policies concerning the expansion of crop acreage, development of irrigation, and improvement or expansion of the grazing areas is essential to the formulation of a constructive plan for improving the utilization of land in El Dorado County. Information already presented indicates the futility of further expansion of the acreage of orchard crops for a number of years. For the same and other reasons further irrigation development would not be feasible. It has been pointed out that the bringing of additional acreage under irrigation, even in projects already constructed, probably would be accompanied by increased costs per acre. These considerations involve broader economic aspects which have an important bearing upon a plan for land utilization.

Influences Affecting the Future Requirements for Crop Land.Crop surpluses are a perplexing agricultural problem, and, if the causes have been properly diagnosed, ${ }^{23}$ will continue for some time to aggravate the agricultural situation.

These difficulties are likely to be intensified if the tendency towards nationalism continues on the part of the nations of the world, each one trying to strengthen its home production of commodities by building up stronger and stronger tariff walls, by the granting of bounties, the regulation of foreign exchange, and the creation of numerous other re-

23 This discussion on population and crop-land requirements is an attempt to summarize the more or less erystallized opinion of the agricultural economics profession rather than to give the personal views of the authors of this bulletin. 
strictions to import trade. Indeed the continuance of such conditions is likely to be at least as determinative with respect to future market conditions for agricultural products as are domestic conditions, in view of the fact that the United States has never since its early days consumed all of its own agricultural products. The monetary systems of many countries are also so seriously out of adjustment that the resulting financial chaos is threatening the commercial relations of the world. Even international debt problems profoundly affect agriculture as well as industry.

Among the major influences that will affect future agricultural crop production, one of the most important is undoubtedly the population which the country can be expected to have to consume such crops. The rate of population growth in the United States and Europe is steadily becoming lower. Within a few decades, population experts tell us, the United States will arrive at a stationary or declining population.

Recent technical writers on the subject of population explain that the true situation with respect to probable future rates of growth has been obscured by the great increases in the population of the country during past decades. Because of this large and long continued growth there has been a widespread belief that the nation's population would continue to expand indefinitely.

From 1920 to 1930 the increase in United States population was about $16,820,000$. Before the end of the decade in which this rapid growth took place, however, the actual rate of population increase had been reduced to a little more than half of that prevailing at the beginning of the decade in 1920. The underlying causes of the change that has been taking place began to affect the composition of the population many years ago. The more important of these are a declining birth rate and federal limitations upon immigration.

The reduction in the number of births in recent years has been so drastic that when the children that were born from 1925 to 1930 are old enough to become mothers and fathers their number will not be large enough to prevent a further pronounced drop in the birth rate. In view of widespread opinions concerning the underlying causes of the unemployment problem in the United States, it does not seem likely that the slackening population growth of the country will be checked in any major degree by letting down the barriers against immigration which this country has built up in the past.

While the more violent effects of these population changes are a number of years in the future, markets for crops undoubtedly will be affected by the decline in rate of population increase, which is already in progress. 
Studies in the United States Department of Agriculture of the relation between agricultural production and population growth have molded professional opinion firmly against programs of crop expansion. ${ }^{24}$ Investigations of the effects of the phenomenal increase in agricultural production in the United States following the World War have strengthened these negative policies. Although average crop yields per acre have not been materially increased in recent years, production of livestock products, increased utilization of land for intensive crops, and substitution of mechanical power for horse power, among other reasons, have contributed to the rapid increase in production with less than a proportionate increase in acreage.

Whatever the causes and the ultimate permanence of all these developments, they are generally agreed to establish a weighty argument against the probable profitableness of expansion of orchard or other agricultural-crop acreage for some years to come.

All available evidence supports the conclusion that the wise policy for El Dorado County in the immediate future will be to entrench on the present frontier of conmercial agricultural expansion, and fortify the progress already made before advancing farther.

Necessary Adjustments in Irrigation-Farming Areas.-Adjustments in the intensively farmed fruit-production areas are necessary because of the prospects of low prices and curtailed programs of expansion. It has been stated that one way of meeting the situation is by providing the residents of these areas with supplementary incomes by fostering local industries. In addition to such steps to increase outside sources of income, certain changes in the utilization of land on individual farms have been indicated which can more completely provide food for the farmer's family, and thus improve indirectly his cash income.

But the problem is not entirely an individual one. The decline in the economic position of agriculture and the apparent certainty of slow recovery will make inevitable lower irrigation-district revenues with which to meet long-time obligations. This situation makes more necessary the improvements in farm income which may be possible, as previously indicated, through changes in land utilization and farm organization. Even with the maximum feasible help to district finances from this source, there may be aniticipated lower district incomes than those upon which present financing was predicated. Group action should therefore be directed to the protection of the financial integrity of the district, upon which the credit of the individual farmers depends. The refinancing of the district in such a way that annual water costs will be

24 Baker, O. E. The prospect for consumption of farm products. California State Dept. Agr. Mo. Bul. 22(1):44-58. 1933. 
consistent with the expected returns from the area served will be ultimately in the best interests of the district bondholders and of bankers and all other agencies loaning money to the farmers, just as much as in that of the farmers.

If the El Dorado Irrigation District endeavors to increase financial revenues by maximum development of the irrigated area, and if all other districts were to adopt a similar policy, it would obviously defeat their own objective, through the depressing effect of increased crop production upon the prices received for those crops. The costs of putting the new lands under irrigation, which must be shared by the lands already irrigated, would also add to the distress of the latter lands. These potential dangers emphasize the necessity, already indicated, of a united policy respecting the expansion of irrigation and crop acreage as a requisite of effective planning for common betterment.

\section{ABANDONMENT OF FARMING ON AN UNPRODUCTIVE FRONTIER}

If some way could be found to eliminate the scattered and isolated farms from extensive areas in El Dorado County, important economies would undoubtedly result in the administration of roads and schools. It is estimated that the utilization of these lands for other important purposes would give returns which in the aggregate would be sufficient either to reimburse the owners of the farms for losses sustained by their surrender or to provide some other means of livelihood which would be more economical for the individual, the county, and the state than if the areas were continued as sparsely populated communities.

It is recognized that under the economic conditions which prevailed in the years following 1929, many families went into the foothill region to escape the high overhead costs of the cities or of the more intensively farmed areas of the state. Increased activity in mining stimulated this movement. As meager as were the average returns from mining, or the other activities to which such migrants turned, living costs were extremely low and with other attractions of the foothills seem to have accounted for at least a temporary reversal of the declining trend in population previously noted.

The suggestion for zoning of certain areas to uses not requiring a population has been made with a knowledge of their value as a place of refuge during periods of economic stress and should not be taken as a proposal either to depopulate the whole foothill area or to confiscate property rights ruthlessly. The means of accomplishing the zoning of areas in accordance with the uses which appear best calculated to promote the prosperity of the county are discussed on page 111. With respect to the best use of lands which may not require a resident popu- 
lation, it is essential to have a clear understanding of what such lands could contribute under appropriate utilization rather than to judge the zoning proposal on the basis of the uses of the past.

\section{UTILIZATION OF WILD LANDS}

Lands which are not cultivated or put to other intensive uses, such as farmsteads, roads, or village and city purposes, are popularly grouped under the designation of "wild lands." Most of the wild lands of El Dorado County are capable of yielding more than one product, use, or service, such as timber, grazing, wild game, recreation, or watershed protection. Under present conditions, however, most private ownership of such land is based on one use only. In the competition of different uses, the necessity of immediate income and the difficulty of specialization in a large number of enterprises compel the single-use owner, such as the lumberman or the livestock man, to sacrifice all opportunities for utilization other than the one in which he is engaged.

Yet, in the long run, the prosperity of the county and the state, as well as that of the individual owner, would be increased if all of these sources of income and service could be utilized in an harmonious coördination which would safeguard the integrity of each use. Coincident with the direct individual and public benefit from increased returns per acre there should result indirect benefits from the stabilizing influences of planned utilization and from the prevention of impairment of the land.

Permanency of Resources Essential.-Basic to the realization of a plan of utilization for many purposes is the principle of conducting each use so as to maintain the permanency of the resources upon which that use depends. The application of this principle to wild land having resources such as forage and timber, and to the utilization of the land for recreation and watershed protection, would be the logical procedure, following the designation of such land as being best suited to such general use. ${ }^{26}$

25 The term "wild land" is in many ways an unsatisfactory one. It is the object, for example, of forestry to transform forest lands from a wild to a managed condition. Nevertheless forest lands have commonly been thought of in the United States as wild lands. So also in the West have grazing lands been considered. Grazing lands within the boundaries of farms in western El Dorado County have been used or treated for the most part in no essentially different way than are the wild mountain lands which are also used for livestock grazing. "Wild land" is here used, therefore, for want of a better term to designate all land which is not cultivated or put to other intensive use.

26 Such designation, however, would be impossible without some anticipation of the details of utilization to be carried out in an area following its classification as wild land. There would be little point to the abandonment of scattered farming in an area if there were not an effort made immediately to establish a new type of utilization. The utilization which has been characteristic of the greater portion of the wild lands surrounding the scattered farms of the county is by no means a basis upon which to visualize this new utilization. This brief discussion of wild-land utilization is designed to make it possible to look towards a future utilization in terms of what it could be made rather than of what it has been. 
In a lumber enterprise, for example, limiting the size of plant and output to that which can be supplied by the timber growth from the lands upon which the sawmill will be dependent not only helps to insure the permanency of the enterprise with respect to timber supply but also reduces the otherwise excessive carrying charges by lengthening the period of investment service and reduces the dangers growing out of overexpansion of production capacity, which has been so large a cause of recent trouble in the lumber industry. An early day lumbering industry in areas of western El Dorado County, where there is now only brush or second-growth timber too small to be cut with profit, disappeared so completely as to leave only names on the map to indicate its former existence. Had that industry cut its timber with regard to a continued supply, based on the growing capacity of the land, it would not have been necessary to wait a hundred years without appreciable revenue from those lands.

In a livestock enterprise, limiting the number of animals to that which can be carried by the lands upon which they will graze without depleting the forage-producing capacity has similar advantages in the long run both for the individual owner and the industry as a whole. Throughout most of the foothill region, of which western El Dorado County is a part, for example, the grazing of livestock has led to extensive overgrazing. This overgrazing has caused widespread deterioration of the range and of its forage-producing capacity. The frequency with which property fences form the dividing lines between grazing lands of high carrying capacity and of very low capacity affords evidence of widely divergent extremes in range utilization and of the possibilities of constructive policies in such utilization.

Similarly in the utilization of wild lands for recreation and game, it is necessary to maintain permanently the conditions essential to such use. Recreational uses frequently can be combined with other uses, but examples have previously been given of certain cases in which it becomes necessary to limit the number and kind of supplementary uses in order to maintain the conditions suitable for the dominant use.

Water run-off from the greater portion of the county is tributary to five of the larger reservoir sites which are a part of the state water plan. Although the construction of these reservoirs is not contemplated in the immediate future, their maintenance when built will be greatly affected by the extent to which silt and debris are brought into them from the watersheds from which they derive their water. In many areas watershed protection will be accomplished by the utilization of land for other purposes. However, on lands having a low value for other purposes and the run-off from which is tributary to reservoir sites, the mainte- 
nance of a permanent erosion-resistant cover is a special and important type of utilization.

Relation of Management to the Economical Utilization of Wild Lands. - Land adapted to many uses needs a management which will take account of all the uses. Such a form of management, flexibly applied to adjust uses to needs, is more difficult to carry out than is management for a single use, but it has the advantage not only of safeguarding all the uses of the land but also of realizing from it in the total a larger return, in most cases, than can be realized permanently from any single use. The weight of the pioneer attitude towards wild lands, as only a reservoir of supply of land and its resources for the use of the citizens as each one pleases, is still so great in the thinking of the American people that the public often is unaware that any organized management is necessary for wild lands or that the absence of such management may bring long-time injury both to the individual and to the community or the state.

The realization of management for many uses, on private lands, may call for public regulation in order to safeguard those who would be willing to undertake it against the competition of those who would take unfair advantage by neglecting or avoiding their responsibilities. In other cases coöperative or some other type of group action may be necessary to accomplish the specific objectives sought. In cases of exceptional conflict between uses, the land may have to be owned and its utilization administered by government. In El Dorado County such management is already in operation on the National Forest.

For the wild lands of El Dorado County, those uses, that form of land ownership, and that type of management will be best which can best combine permanent private profit and the many community services which should be rendered by such lands.

\section{REORGANIZATION OF THE LIVESTOCK INDUSTRIES}

Important changes in the organization of the livestock industries are essential to the realization of range improvement and more efficient production and utilization of livestock feeds. Of these changes, one group is closely related to, or a part of, the program just discussed of eliminating the scattered farms in certain areas. They would consist of the abandonment of livestock farming under certain conditions and the substitution of either a more extensive system of range utilization or some other method of utilization not directly associated with the livestock industry. A second group of changes would include various measures for the establishment of the remaining areas utilized for livestock production on a more economical basis. Some of these measures would involve the reor- 
ganization of individual farms such as the consolidation of small holdings into larger and more efficient units or the organization of diversified livestock farms in areas having suitable combinations of soils so as to take advantage of the combined productivity of crop land and pasture.

Changes in the organization and management of livestock enterprises and in the ownership of land, together with governmental assistance or coöperative agreement among landowners and livestock men, would also make possible the progressive use of ranges at different elevations, moving livestock up the slopes as the season advances. Of a somewhat different character are proposals to accomplish by group action objectives such as the coöperative utilization of distant ranges by owners of herds and flocks which are too small for the economical utilization of such feed by the individual owners operating independently. Where landowners can come to agreement among themselves and with federal and state officials, there is also opportunity for group action in the formulation and execution of policies of land-clearing, range improvement, and fire control.

Range Improvement Policy.-A question now may be raised concerning the application of policies of agricultural expansion to the improvement or extension of the range. What is the relation of the utilization of California ranges to the economic position of agriculture? There are two important phases of this question.

California ranges bear a different relation to California than they do to the rest of the United States. The peculiar relation which they bear to California arises from the large proportion of the California meat supply which is imported from other states, the importance of alternative uses of irrigated land made necessary by reverses in the fruit industries, and certain nutritional and seasonal deficiencies of the range feeds which may be made up by supplemental crops. During the five years immediately preceding the depression which began in 1929, the net shipments of cattle into California from other states for immediate slaughter and as feeders averaged 59 per cent of the total live weight of beef and veal slaughtered in the state. The remaining 41 per cent was produced in California beef and dairy herds. Of the California sheep and lamb slaughter, a larger proportion was produced in California, all but a little less than 7 per cent being produced in the state.

California livestock producers probably could not compete with other states if it were not for the low-cost feed produced on the ranges. It is estimated that nearly 45 per cent of all livestock feed used in the state is pasture, a large part of which is wild grass. The percentage of crop feeds, however, has been increasing. 
In the beef and sheep industries supplementary crops will probably continue to play a more and more important rôle. There is, however, an economic limit to using crop feeds produced on irrigated lands, their most important use being to supply, especially for breeding stock and young animals, certain nutrients not present in sufficient amounts in some of the range grasses; to provide feed at a time when range grasses are not available because of seasonal climatic conditions; and to finish livestock for market. For certain types of livestock and under special situations, there are undoubtedly cases in which irrigated pasture and other crop feeds will continue to be used to advantage the year round. Undoubtedly sufficient crop feeds, including irrigated pasture, could be produced in California to supply the entire livestock industry of the state. The economy of such a shift, however, is very seriously doubted. A maximum use of irrigated lands in California for producing livestock feeds seems possible only with a maximum range area and capacity. Adequate range area and capacity to supplement feeds produced on irrigated land is necessary to make such use of the crop land sufficiently economical to enable California livestock men to compete with other states.

But the effect of increased livestock production upon prices and the seriousness of too severe competition cannot be ignored. The national situation will undoubtedly demand a conservative policy with regard to expanding the livestock industries. The acquisition by the federal government of lands which might otherwise be improved advantageously by California stockmen for expanding their feed resources, may present a means of reconciling state and national interests. Control of production may not in itself constitute a basis upon which such purchases could be made. Other public advantages to be gained by federal acquisition have been shown to give certain of the lands a greater value in federal ownership than they would have in privately owned stock ranches. These values, if they can be translated into terms of purchase prices, may more than offset the advantages to the private owners of clearing the lands for grazing.

Criteria for Determining the Limits of the Livestock Ranching Area. -A determination of the limits of the area within which livestock production probably in the long run will continue to be economical rests upon a number of complicated considerations. A distinction already has been made between the possibility of continuing in the livestock business and the profitableness of doing so. It has been stated that an excess of returns over costs is essential if an area is to continue as a livestockproducing area, but other questions must be answered before a decision can be reached that the area should continue to produce livestock. From 
the standpoint of the landowner who is also a livestock producer, possible net returns from other uses of the land and other opportunities for employment are important considerations. ${ }^{27}$

As difficult as these questions are they are complicated further by variations in prices of livestock products and of materials purchased and in wages paid for hired labor.

Policies of taxation are also of importance. The 1930 tax was shown to have constituted 24 per cent of the El Dorado County beef producer's costs. Changes in assessed values and in tax rates within an area would be followed by corresponding changes in the economy of livestock production in that area.

Furthermore, the use of one area for livestock production cannot be considered apart from the use of other areas. The most difficult problems of range management in El Dorado County occur between the elevations of 1,000 feet and 3,000 feet. Grazing in these areas is difficult because of the character of the land and the problem of controlling brush. The forage upon them is usually at its best in the early summer, after the grass in the lower areas has become dry and before the mountain ranges are ready for use. The greatest value of the grazing lands situated at the intermediate elevations, therefore, would seem to be in connection with the progressive utilization of the lower and higher areas.

There are exceptions to the advantages of such use where crop land and irrigation water make a different system of farming more economical. Before a final judgment can be reached, therefore, the net returns from a ranching system depending entirsly upon the grass and browse maturing at different stages during the season must be compared with probable returns from a system of livestock production in which crops or irrigated pasture produced upon irrigated areas in the valleys and foothills take the place of the grazing at the intermediate elevations and in some cases the high mountain areas. ${ }^{28}$

From what has just been said, and the previous discussion of the relation of grazing to the state and the national agricultural policy, it can be seen that the line between forest and range cannot be drawn with mathematical precision. The factors which have determined the approximation of the limits of the livestock area presented in this bulletin are:

27 The emphasis would be shifted from alternatives in the use of the land to alternative opportunities for employment as the consideration of the problem is shifted from the landowner who is not using the land himself to the owner-operator, the part owner, and finally to the tenant.

28 In the economic classification of land in El Dorado County, careful consideration has been given to the relative advantages and disadvantages of these different general systems of ranching. Detailed comparisons of costs and returns will not be possible, however, until more information on costs and returns is available for the alternative methods of land utilization. 
the costs and returns from present methods of farming on lands of different character; the possibility of improving those returns by changes in methods of ranching and by supplemental returns from forest crops; state and national interests and policies; methods of taxation; costs to the state and county for the maintenance of roads and schools; alternative nonagricultural uses of wild lands; alternative opportunities for the residents on the land; and costs of range improvement. Some of the more important of these have been subject to measurement. Others have been matters of judgment. The line, which has been drawn with great care, is subject to alteration as changes are made in policies and as new knowledge is developed. The realization of the plan presented for the utilization of the livestock area will depend upon the energy and skill with which the individual and community action needed are applied.

Consolidation of Holdings into Larger Units.-Proposals for the consolidation of farming units in certain areas are based upon the greater efficiencies observed on the larger ranches, a definite existing trend toward larger holdings, the necessity of larger units in the development of economical methods of brush removal and grazing practice, and the possibility of planning units in such a manner that on certain large areas road construction and the maintenance of schools can be eliminated. Larger units in any area, however, would result in fewer people on the land. Decreasing the density of a population already sparse may be justified by the absence, in the areas where such consolidations are suggested, of opportunities for making a living on a small ranch and by the possibility of eliminating population completely from extensive areas. The small remaining population could be concentrated in areas where other enterprises would make it economical for roads, schools, and other conveniences to be provided.

Progressive Use of Ranges at Different Elevations.-Attention has been called to the need of some source of feed after the valley pastures have become dry in the spring and before the mountain ranges are available. The progressive use of ranges at different elevations, going higher as the season advances, would greatly extend the total green-feed period over what is possible upon most individual private ranges. This would correspondingly decrease the annual amount of supplementary feed required, which usually has a higher unit cost when produced on crop land except in the cases where the herd is so small that herding costs and expense of moving the stock consumes the advantage gained in the use of grass feed. Furthermore, because of the greater amount of green feed, it would result in bringing the stock to better condition, and, therefore, higher sale value.

At present those using mountain range usually make one move from 
their winter to their summer range. This undoubtedly has its advantage in that winter headquarters and summer headquarters may be made fairly permanent. Some of the livestock enterprises might continue more profitably on this basis. On the other hand, it seems that there is opportunity for the reorganization of a number of the ranching enterprises so as to utilize much of the grass at elevations between the lower and higher altitudes at a more economical time and with more permanent benefit to the ranges than has been realized under past conditions. This problem could doubtless be worked out advantageously by individuals or groups of stockmen in coöperation with the National Forest Administration, with a view to the greatest benefit to the livestock industry as a whole.

Group Action in the Utilization of Grazing Lands.-A number of other problems associated with the utilization of grazing lands require group action in their solution. A considerable acreage of land, although it may be retained in private ownerslip, will probably yield greater returns if placed under a system of management similar to that suggested for wild lands. Large areas of land, including a number of ownerships, probably could be brought under one general policy and plan of utilization as far as certain specific objectives are concerned, while in other respects they might be managed as individual holdings. On the ranges of the foothills there are many serious problems which demand just this sort of reorganization.

Preliminary inquiries in El Dorado County into the causes of lack of success of coöperative grazing associations indicate that such grazing enterprises have usually been formed during periods of high prices or during periods of drought and have broken down under less favorable price conditions or during a season of more favorable rainfall. A change in these conditions causes at least a temporary change in the relative incomes under the different methods of operation. A further cause of lack of success has been held to be the varying character of the different lierds. Complaints have been made, in the case of sheep associations of this kind, that the different bands of sheep would stray away from each other, causing a great amount of trouble in herding.

In some other localities the sucess of such grazing associations has been greater than in El Dorado County. A majority of the bands of sheep grazing on the mountains near Ephraim, Utah, are made up from the flocks of from 10 to 50 National Forest permittees, and, except for depression years, associations of such owners have been successful. One association of that locality composed of over 50 individuals is cited as having paid its dividends regularly for more than fifty years. ${ }^{29}$ The

29 Letter from J. W. Humphrey, Forest Supervisor, Manti National Forest, to A. W. Sampson, June 5, 1933. 
valuation of grazing privileges in the Manti Forest has been very high, probably as a result of these associations.

The control and proper use of fire cannot be confined to an individual land holding. Just what part fire is to play in the future management of these lands is uncertain. Specialists are endeavoring to determine the best methods of increasing and preserving the grazing and carrying capacity. In any event, whatever policies may finally develop, adjacent landowners will be affected by the policies of each other. More definitely, effective results probably could be obtained if these policies could be more or less standardized and controlled through local organizations in coöperation with state and federal authorities than by separate individual action.

The Brush Problem.-For the removal of brush and its replacement by grass, where grazing is the best use of the land, or by timber on sites more favorable for profit from timber growing, there is urgent need for methods which are effective and cheap and at the same time without damaging results.

Fire has been used for this purpose mainly because it has been the cheapest means available and was at least immediately effective. In some cases it has resulted in converting chaparral to grass. In others it has only resulted in extending the brush area. Too little is yet known of the reasons for success or failure. If fire can be made a good servant without entailing damages, both public and private, larger than its benefits, much will have been gained. The difficulty with indiscriminate broadcast burning is the lack of control. There is always danger of the fire spreading into areas which should not be burned, such as those to be devoted to forest-growing or those important for watershed control. Broadcast burning has had three-quarters of a century of trial, from which the evidence is clear that it has resulted in a continuously increasing total brush area, which has invaded both upward into that formerly occupied by the forest and downward into that of the grass.

\section{A PROGRAM OF LOCAL INDUSTRIAL DEVELOPMENT}

It is of importance to El Dorado County agriculture, for reasons previously given, to secure the permanency of existing industries, and, where further investigation may show such a step to be feasible, to promote such new industries as will make more complete use of El Dorado County resources such as minerals and wood products. Agriculture in the county needs the supplementary employment which industries can afford. Employment in mill and forest, in the fruit houses or on the roads, selling wood, teaching school, and giving music lessons are examples of such employment which has been available to some, although 
under the conditions of depression from 1930 to 1933 at lower wages and less steady employment than formerly. The extent to which investments already made in many farms can be salvaged will depend upon the amount of such supplementary employment.

In the immediate vicinity of Placerville and Diamond Springs, dependence of orchard agriculture upon supplementary industrial income is emphasized, in the first case by the unfavorable topography and frost damage in the low places, and in the second by relatively shallow soils and late-season water shortage. It has been possible to develop the scattered tracts of productive soils only because of opportunities for supplemental employment of their owners in the sawmills and town industries.

A general policy of local industrial development, and, with it, the concentration of available water supplies upon the more favorable cropproduction areas, including small acreages of diversified products for home consumption, could be made to increase community welfare. The utilization of steeper farm areas for well-managed woodlots and the development of tributary wood-using industries could further contribute to farm revenues, and, by means of such forest revenues from lands not in agricultural crops, decrease the pressure to cultivate such lands in advance of the need for agricultural products.

\section{THE MANY USES OF LAND AND THEIR RELATION TO EACH OTHER}

Enough has been said in the foregoing pages to indicate the interdependence of the various uses of land. It has been observed that land utilization has been influenced not only by the soil types found in each locality and other growth factors such as climate and topography, but also by the manner in which different classes of land are distributed in relation to each other. In other words, the utilization of a given tract of land is governed not alone by its character, but also by the character and utilization of adjoining lands. Hence, the uses of different kinds of land are frequently closely related.

This is particularly true of irrigated land. An extensive area of irrigable land in one contiguous tract can be irrigated and farmed more economically than scattered areas of the same kind of land. But it has been demonstrated how varied is the character of the land in El Dorado County irrigation projects, and how the utilization of each of the tracts of land within such a project bears upon the success of operating the entire system. Suggestions have also been made concerning the possibilities of using some of the dry lands within such projects in conjunction with the farming of the irrigated land. The few instances where landowners are successfully operating their farms on such a basis are good 
illustrations of the importance of considering the adaptation of adjoining areas in planning the utilization of land.

Similarly, it has been noted that deep fertile soils interspersed in small detached bodies among grazing lands may require, in the interests of economy of using both of these classes of land, a different type of utilization than similar soils situated in large contiguous tracts. The most efficient use of much foothill grazing land requires summer use of mountain grazing lands. This in turn requires lower areas providing winter feed.

The complementary relation between agriculture and industry may be just as essential to the success of the manufacturing industry as for the success of agriculture. Managers of local industries in El Dorado County have stated that one of the greatest costs of industry is the turnover of labor. A small tract of agricultural land may insure the permanency of labor.

Looking farther into the future, a forest erop on lands now giving little or no return may be the determining factor in the economy of using adjacent lands for farming. This reasoning applies to areas small and large alike. It will be exceedingly advantageous to the people of the industrial and agricultural area about Placerville to have the most efficient uses made of the extensive adjacent areas, whether those uses be grazing, forestry, stock-raising, or recreation.

It is important that these different kinds of uses be balanced uses, however. The over or underdevelopment of any one type of utilization, especially where that use is dependent upon other local enterprises, may result in depletion of other resources apparently unimportant but vital to the economic equilibrium of the community. The same reasoning may be applied to the relation of land use within a local community to that of the state or nation.

It is clear that an economic classification of the land is necessary for the purpose of determining what areas are suitable for intensive development for agriculture, what areas should be retained as chiefly livestockproducing areas, and what areas should be temporarily or permanently maintained in or restored to their natural condition and utilized primarily for providing valuable services and materials for which such land is particularly well adapted. At first thought, such an economic classification might be expected to set apart those lands which are best suited to fruit production, other areas where livestock might prove to be most economical, and still others in which forest crops would be the best utilization. It has been found, however, that in every area which may be set apart as a geographic unit, the utilization within that area is so complex that instead of single uses, combinations of uses must be considered. 
Instead of a fruit-production area, therefore, it is found that fruit production in combination with forest crops and industrial development is likely to be the most.economical combination under the conditions found in the fruit-growing areas in El Dorado County.

In those areas which are not intensively developed for agriculture but in which certain agricultural potentialities exist, the forest-crop possibilities are sufficiently important to indicate that a combination between agriculture and forestry may prove to be more economical in these areas than a complete destruction of the forest for the purpose of agricultural development. Similarly, in the area adaptable to livestock production, the natural characteristics of the land are so variable that for certain portions of the county one system of livestock production will be found to be most economical, whereas under other conditions an entirely different system will be found to fit more nearly the physical character of the land. The production of livestock sometimes can be carried out more economically if supplemented in one case by a forest crop and in another by the production of livestock feed.

In those areas having recreation values some return from forest and from grazing seems possible, and whereas, without planning the utilization of such areas, conflicting interests might arise, it seems possible with such planning for most uses to supplement rather than to conflict with other uses of the same land. The highest benefit to the community, and ultimately to individual users of land, will acerue if land uses are so guided that, instead of each being the sole use of a given area, as many uses are simultaneously carried on as can be coördinated profitably on the area with the assured maintenance of the resources used. Land-use planning, therefore, is seen to involve a consideration of many uses of land of different classes rather than the segregating of lands according to specific single uses.

\section{GENERAL ECONOMIC CLASSIFICATION OF EL DORADO COUNTY LANDS AND SUGGESTED PROGRAMS} OF UTILIZATION

The 480,319 acres, representing approximately 43 per cent of the total area of El Dorado County, which lie below the western boundary of the National Forest, have been divided for investigation into 32 different subdivisions, based upon the physical character of each. Each of the subdivisions has been subjected to economic investigation including estimates of income and utilization. On the basis of these investigations, these areas have been regrouped into four major economic classes. Above the National Forest boundary the forest-crop area is extended up to the 


\section{TABLE 14}

Land Classes and Land Utilization in Western El Dorado County

\begin{tabular}{|c|c|c|c|c|c|c|c|}
\hline \multirow{3}{*}{ Utilization } & \multicolumn{7}{|c|}{ Economic classification areas of figure 13} \\
\hline & \multicolumn{2}{|c|}{ Area I } & \multirow{2}{*}{ Area II } & \multicolumn{2}{|c|}{ Area III } & \multirow{2}{*}{ Area IV } & \multirow{2}{*}{ Total } \\
\hline & A & $\mathrm{B}$ & & $\mathbf{A}$ & B & & \\
\hline Land area, acres... & 25,979 & 14,441 & 45,116 & 89,949 & 40,107 & 264,727 & 480,319 \\
\hline \multicolumn{8}{|c|}{ Land classes, in per cent of total area } \\
\hline Class 1 land. & 56.0 & 19.0 & 41.0 & 7.0 & 15.0 & 17.0 & 19.4 \\
\hline Class 2 land & 9.0 & 9.0 & 40.0 & 0.0 & 0.0 & 4.0 & 6.7 \\
\hline Class 3 land & 20.0 & 28.0 & 0.0 & 50.0 & 74.0 & 2.0 & 18.6 \\
\hline Class 4 land & 1.0 & 11.0 & 7.0 & 21.0 & 0.0 & 12.0 & 11.6 \\
\hline Class 5 land & 14.0 & 33.0 & 12.0 & 22.0 & 11.0 & 65.0 & 43.7 \\
\hline Total & 100.0 & 100.0 & 100.0 & 100.0 & 100.0 & 100.0 & 100.0 \\
\hline
\end{tabular}

\begin{tabular}{|c|c|c|c|c|c|c|c|}
\hline A rea in towns & 0.1 & 5.8 & 0.2 & 0.1 & $*$ & $*$ & 0.2 \\
\hline Orchard and vineyard & 20.3 & 16.2 & 2.6 & 0.5 & 0.8 & $0.7 \dagger$ & 2.4 \\
\hline Hay and annuals $\ddagger \ldots . . .$. & 4.0 & 1.8 & 3.2 & 0.6 & 3.4 & $0.9 \dagger$ & 1.5 \\
\hline Grassland $\$ \| \ldots \ldots \ldots \ldots \ldots$ & 26.4 & 11.4 & 20.7 & 9.2 & 21.7 & 11.6 & 13.6 \\
\hline Grassland§ฯ & 1.7 & * & 0.8 & 66.2 & 16.3 & 2.6 & 15.3 \\
\hline Woodland and chaparral\| & 26.4 & 31.0 & 18.8 & 6.7 & 33.5 & 15.6 & 16.8 \\
\hline Woodland and chaparralף & 1.1 & 0.5 & 1.0 & 16.0 & 22.4 & 8.6 & 9.8 \\
\hline Second-growth timber** & 19.7 & 33.3 & 52.7 & 0.7 & 1.9 & 45.5 & 32.4 \\
\hline Virgin timber & 0.3 & * & $*$ & $*$ & $*$ & 14.5 & 8.0 \\
\hline Total ........ & 100.0 & 100.0 & 100.0 & 100.0 & 100.0 & 100.0 & 100.0 \\
\hline
\end{tabular}

Utilization according to type of farm in per cent of total area

\begin{tabular}{|c|c|c|c|c|c|c|c|}
\hline Fruit-farm area & 43.2 & 23.9 & 4.6 & 1.5 & 0.0 & 2.8 & 5.3 \\
\hline Fruit and livestock farms. & 24.3 & 5.6 & 10.2 & 0.7 & 5.6 & 9.6 & 8.3 \\
\hline 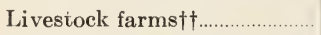 & 12.5 & 8.6 & 48.1 & 87.3 & 62.7 & 39.8 & 49.0 \\
\hline Grain farm area & 0.0 & 0.0 & 1.1 & 0.0 & 0.0 & 0.0 & 0.1 \\
\hline Farms used for residence only & 1.1 & 23.2 & 14.7 & 3.6 & 8.2 & 6.7 & 7.2 \\
\hline & $\overline{81}$ & $\overline{613}$ & $\overline{787}$ & - & $\overline{76}$ & $\overline{580}$ & $\overline{60} 0$ \\
\hline Land not in farms...... & $\begin{array}{ll}81 & 1 \\
18 & 9\end{array}$ & $\begin{array}{l}01.3 \\
38.7\end{array}$ & 21.3 & $\begin{array}{r}93.1 \\
6.9\end{array}$ & $\begin{array}{l}16.5 \\
23.5\end{array}$ & $\begin{array}{l}58.9 \\
41.1\end{array}$ & $\begin{array}{l}09.9 \\
30.1\end{array}$ \\
\hline Total land area. & 100.0 & 100.0 & 100.0 & 100.0 & 100.0 & 100.0 & 100.0 \\
\hline \multicolumn{8}{|c|}{ Land tenure in per cent of total area } \\
\hline Owner-operated farms... & 75.9 & 60.7 & 57.9 & 58.6 & 47.8 & 35.7 & 46.0 \\
\hline Operated by lessee.......... & 5.2 & 0.6 & 20.8 & 34.5 & 28.7 & 23.2 & 23.9 \\
\hline 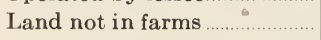 & 18.9 & 38.7 & 21.3 & 6.9 & 23.5 & 41.1 & 30.1 \\
\hline Total land area... & 100.0 & 100.0 & 100.0 & 100.0 & 100.0 & 100.0 & 100.0 \\
\hline
\end{tabular}

* Quantity insignificant.

$\dagger 1,223$ acres not covered by crop survey is prorated on the basis of the 2,961 acres surveyed.

$\mp$ A small amount of land in fallow is included with the grassland.

$\S$ Grassland includes the woodland-grass type which is grassland with an open stand of woodland trees.

|l Deforested area.

I Nonforest area.

** Restocked cut-over area.

$\dagger \dagger$ For itemized data on livestock farms, see table 15. 
high Sierras where a fifth classification suggests recreation for the dominant utilization. The names of the five economic classes given below indicate a combination of uses, the dominant use for each area being stated first:

Area I Fruit production with forest crop and industry.

Area II Potential farm and/or forest crop.

Area III Livestock production.

Area IV Forest crop with recreation and grazing.

Area V Recreation with forest crop and grazing.

TABLE 15

Land Utilization for Different Types of Livestock Enterprises in Western El Dorado County

\begin{tabular}{|c|c|c|c|c|c|c|c|}
\hline \multirow{3}{*}{ Utilization } & \multicolumn{7}{|c|}{ Economic classification areas of figure 13} \\
\hline & \multicolumn{2}{|c|}{ Area I } & \multirow{2}{*}{ Area II } & \multicolumn{2}{|c|}{ Area 111} & \multirow{2}{*}{ Area $1 \mathrm{~V}$} & \multirow{2}{*}{ Total } \\
\hline & A & $\mathrm{B}$ & & $A$ & $\mathrm{~B}$ & & \\
\hline \multicolumn{8}{|c|}{ Utilization according to type of livestock farm, in per cent of total area } \\
\hline Dairy, beef, dairy and beef farms... & 10.4 & 5.0 & 18.2 & 60.8 & 28.9 & 24.8 & 29.9 \\
\hline Sheep farm area & 0.1 & 0.0 & 8.9 & 16.0 & 17.9 & 10.0 & 10.9 \\
\hline Diversified livestock farms. & 2.0 & 3.6 & 21.0 & 10.5 & 15. 9 & 5.0 & 8.2 \\
\hline Total area in livestock farms & 12.5 & 8.6 & 48.1 & 87.3 & 62.7 & 39.8 & 49.0 \\
\hline Other land area ................... & 87.5 & 91.4 & 51.9 & 12.7 & 37.3 & 60.2 & 51.0 \\
\hline Total land area............. & 100.0 & 100.0 & 100.0 & 100.0 & 100.0 & 100.0 & 100.0 \\
\hline \multicolumn{8}{|c|}{ Per cent of total area supplemented by mountain range } \\
\hline $\begin{array}{l}\text { Area in livestock farms supple- } \\
\text { mented by mountain range }\end{array}$ & 7.7 & 3.2 & 7.4 & 58.5 & 19.8 & 26.8 & 28.5 \\
\hline $\begin{array}{l}\text { A rea in livestock farms not supple- } \\
\text { mented by mountain range.......... }\end{array}$ & 4.8 & 5.4 & 40.7 & 28.8 & 42.9 & 13.0 & 20.5 \\
\hline Other land area $\ldots \ldots \ldots$ & 87.5 & 91.4 & 51.9 & 12.7 & 37.3 & 60.2 & 51.0 \\
\hline Total land area...... & 100.0 & 100.0 & 100.0 & 100.0 & 100.0 & 100.0 & 100.0 \\
\hline
\end{tabular}

Figure 13 shows the location of the lands included in these five general economic classifications. The results of the economic investigations are shown in different shades of brown, while the crop and forest types are shown in black hachures.

Tables 14 and 15 indicate the present utilization of the four economic classification areas below the National Forest. The first and third of these have each been divided into two subdivisions because of important differences. These differences will be explained in the following sections devoted to the different areas shown by the table. 


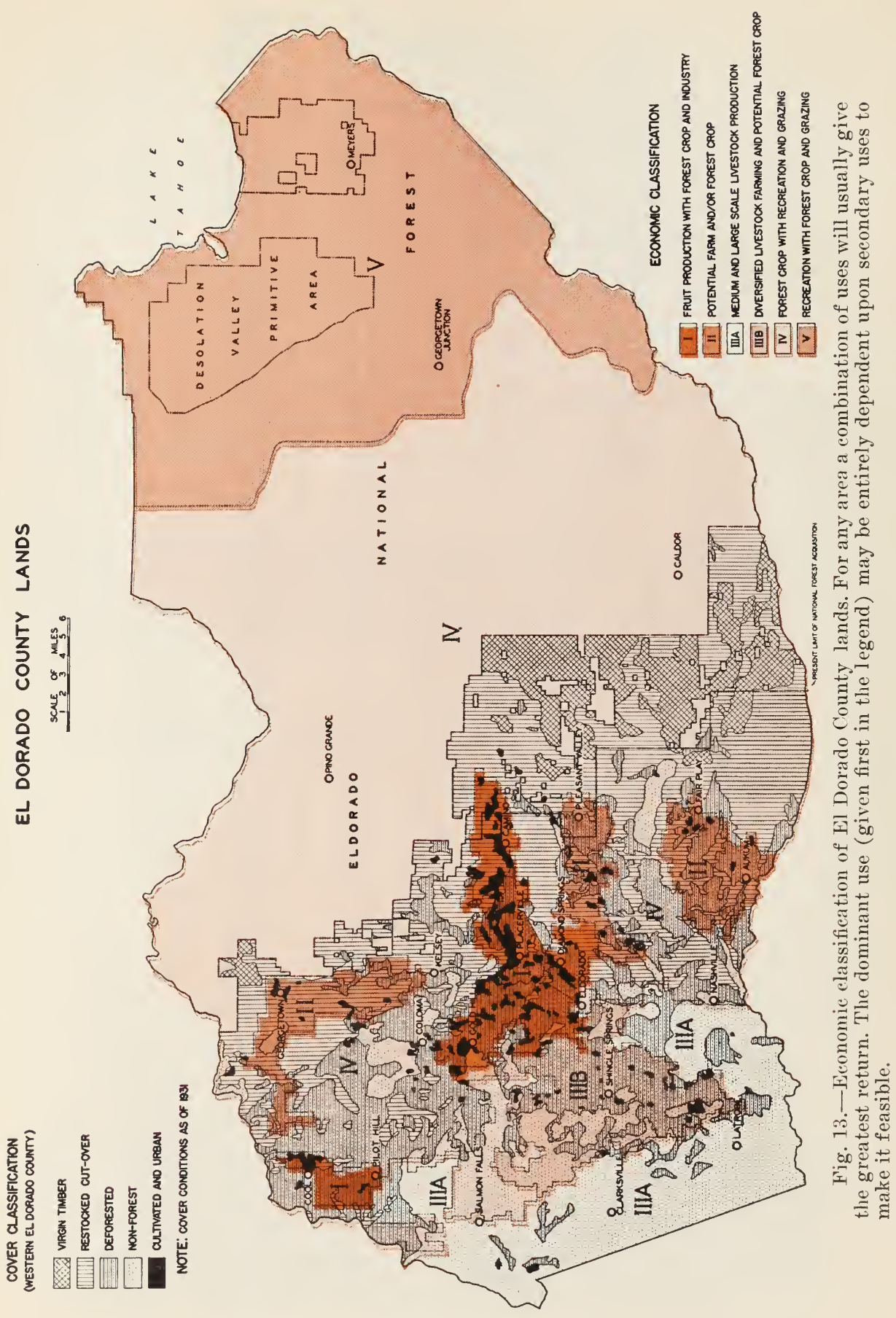




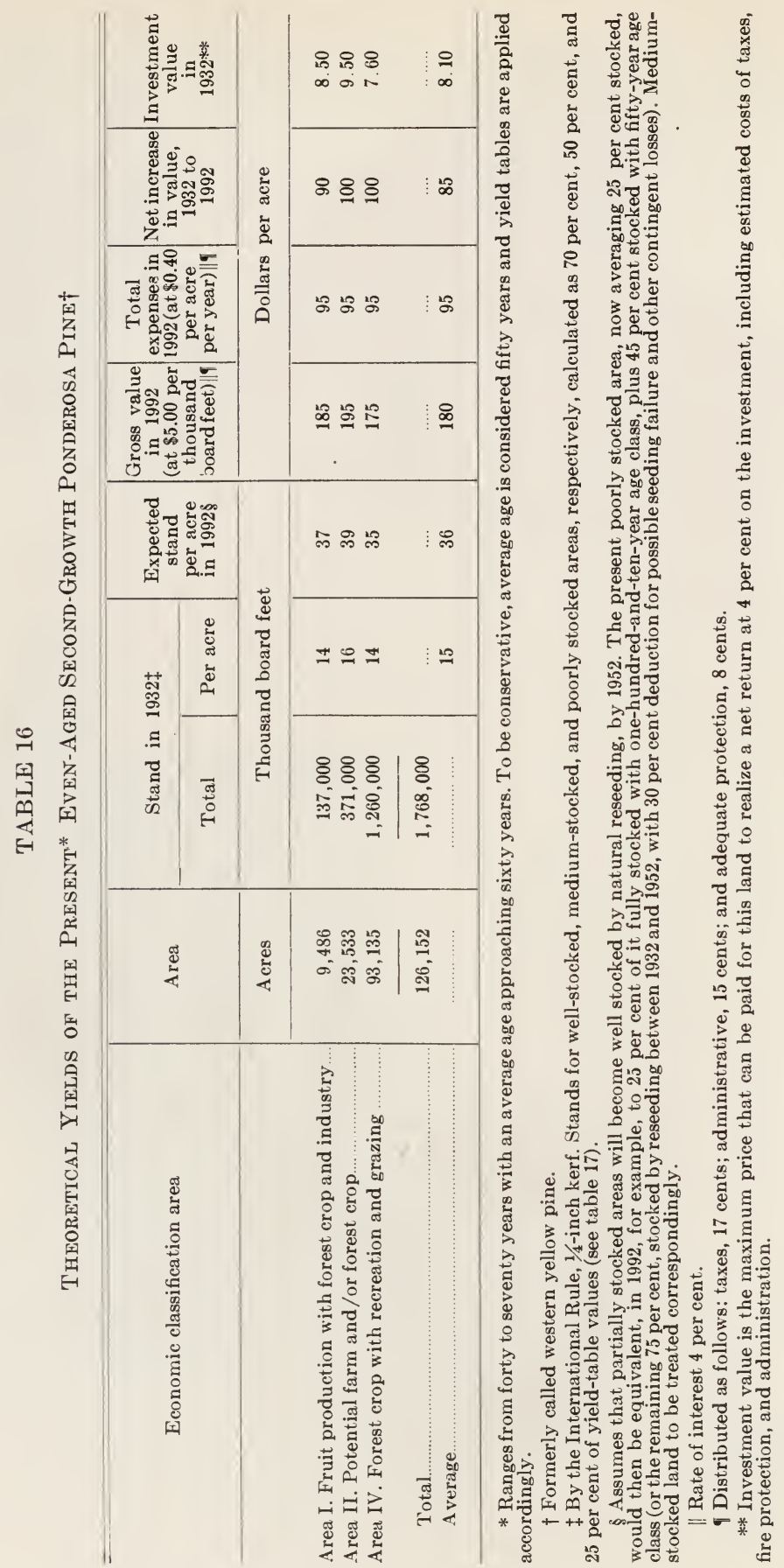


TABLE 17

Theoretical Yield Capacities Under Intensive Forest Management*

\begin{tabular}{|c|c|c|c|c|c|}
\hline \multirow{2}{*}{ Economic classification areas } & \multirow{2}{*}{ Gross area } & \multirow{2}{*}{$\begin{array}{l}\text { Forest and } \\
\text { potential } \\
\text { forest land }\end{array}$} & \multicolumn{2}{|c|}{$\begin{array}{l}\text { Annual yield available } \\
\text { for cutting }\end{array}$} & \multirow{2}{*}{$\begin{array}{c}\text { Gross } \\
\text { annual } \\
\text { income } \\
\text { per } \\
\text { acre† }\end{array}$} \\
\hline & & & Total & Per acre & \\
\hline & acres & acres & $\begin{array}{l}\text { thousand } \\
\text { board feet }\end{array}$ & $\begin{array}{c}\text { board } \\
\text { feet }\end{array}$ & dollars \\
\hline $\begin{array}{l}\text { Area I. Fruit production with forest } \\
\text { crop and manufacturing industry.... }\end{array}$ & 40,420 & $21,351 \ddagger$ & 6,278 & 290 & 0.45 \\
\hline $\begin{array}{l}\text { Area II. Potential farm and/or forest } \\
\text { crop }\end{array}$ & \multirow[t]{2}{*}{45,116} & \multirow[t]{2}{*}{$31,015 \ddagger$} & \multirow[t]{2}{*}{12,410} & \multirow[t]{2}{*}{400} & \multirow[t]{2}{*}{2.00} \\
\hline $\begin{array}{l}\text { Area IV. Forest crop with recreation } \\
\text { and grazing: }\end{array}$ & & & & & \\
\hline Poor grazing land & \multirow{2}{*}{264,727} & 199,285 & 74,435 & 370 & 1.85 \\
\hline Fair grazing and cultivated land.. & & 33,838 & 11,510 & 340 & 1.70 \\
\hline $\begin{array}{l}\text { Area IIIв. Diversified livestock farm- } \\
\text { ing and potential forest crop }\end{array}$ & 40,107 & $14,196 \dagger$ & 3,434 & 240 & 1.20 \\
\hline Total ................. & 390,370 & 299,685 & 108,067 & 360 & 1.80 \\
\hline
\end{tabular}

* Based on 70 per cent of yield table values (see table 18) for fully stocked stands which yields are to be expected when forest area is organized and intensively managed on a sustained yield basis with a rotation at sixty years (cutting timber when sixty years old).

+ Based on a stumpage value of $\$ 5.00$ per thousand board feet. From this gross income should be deducted an annual expense of $\$ 0.40$ an acre to cover costs: fire protection, administration, and taxes.

$\ddagger$ Excludes cultivated land and fair grazing land (grass and woodland-grass types).

\section{TABLE 18}

Total Volume per Acre in Thousand Board Feet Yielded by Ponderosa Pine* in El Dorado County, $\dagger$ by Site Indexes

\begin{tabular}{|c|c|c|c|c|c|}
\hline \multirow{2}{*}{ Age in years } & \multicolumn{5}{|c|}{ Site index } \\
\hline & 50 & 60 & 70 & 80 & 90 \\
\hline & \multicolumn{5}{|c|}{ Yiclds in thousand board feet $\ddagger$} \\
\hline 50 & 10.0 & 15.0 & 24.0 & 38.0 & 53.0 \\
\hline 60 & 14.0 & 21.0 & 32.0 & 46.0 & 63.0 \\
\hline 70 & 17.0 & 26.0 & 38.0 & 54.0 & 71.0 \\
\hline 80 & 21.0 & 31.0 & 43.0 & 61.0 & 80.0 \\
\hline 90 & 25.0 & 35.0 & 48.0 & 67.0 & 88.0 \\
\hline 100 & 28.0 & 39.0 & 52.0 & 74.0 & 96.0 \\
\hline 110 & 31.0 & 42.0 & 57.0 & 80.0 & 1050 \\
\hline
\end{tabular}

* Formerly called western yellow pine.

† See tables in: Behre, C. Edward. Preliminary normal yield tables for second-growth western yellow pine in northern Idaho and adjacent areas. Jour. Agr. Research 37(7):379-397. 1928. These tables are an adaptation to El Dorado County conditions. Since site index in Behre's tables is based on height attained by the average of the dominant and codominant trees in one hundred years and site mapping in El Dorado County was based on the height attained by the average dominant tree in fifty years, it was necessary to determine the equivalent values in each case. In doing this it was assumed that the height of the average dominant tree at fifty years would be 5 feet greater than the average height of dominant and codominant trees taken together. To secure values for the sites of higher indexes, it was necessary to extend Behre's volume curves. It is believed that the values for these tables thus derived are conservative.

¥ International Rule, 1/4-inch kerf. Tops utilized to diameter of 4 inches inside bark. 
The detailed data upon which estimates of the forestry possibilities of western El Dorado County depend are presented in tables 16, 17, and 18. In table 16 are shown, separately by classification areas, the expected yields of the second-growth stands of ponderosa pine in that region; and in table 17 , similarly segregated, are given the calculated yield capacities of the same lands under intensive forest management. Table 18 presents the expected yields of these second-growth pine lands by site classes, as established by actual field measurements of existing trees, upon which the yield capacities and expected yields of the classification areas in the tables preceding it are based.

\section{AREA I, FRUIT PRODUCTION SUPPLEMENTED BY FOREST CROP AND MANUFACTURING INDUSTRY}

This area, which is shown on the map of figure 13, includes lands under the irrigation canals of the El Dorado Irrigation District, the Diamond Ridge Water Company and the lower end of the Georgetown Ditch. Within this gross area of 40,420 acres, about 7,400 acres or 18 per cent are irrigated, while a slightly greater area is in orchard and vineyard crops. This area has been divided for further consideration into two parts : area Iв, 14,441 acres immediately adjacent to Placerville and Diamond Springs, and area $\mathrm{I}_{\mathrm{A}}, 25,979$ acres on the Camino Ridge and west of Placerville.

By referring again to tables 14 and 15 it will be observed that the last-named area has a much larger percentage of class 1 land, a larger percentage of the total area in farms, a larger percentage in orchard and vineyard fruits, and a smaller percentage in brush and timber. A very significant fact with respect to the area adjacent to Placerville and Diamond Springs is that 23 per cent of the gross area and 38 per cent of all land in farms is used primarily for residence.

Since 96 per cent of the gross area in this unit was originally in forest, the production of timber crops is a use the economic value of which should be considered. After eliminating lands now cultivated or in grass, there remain about 21,000 acres that can be devoted to timber crops. Of this area, nearly half, or approximately 10,000 acres, is timbered. Most of the latter consists of sixty-year-old second-growth ponderosa pine, with an average present stand of 14,000 board feet per acre. In table 14 it is shown that this second-growth land has a capitalized investment value for forest purposes of about $\$ 8.50$ an acre, and table 16 shows that the entire 21,000 acres of this land can be expected, under intensive forest management, to produce eventually 6 million feet of lumber a year. Such a yield should more than provide all local needs for lumber and box shook; but El Dorado County is in a strategic position to take 
advantage of the large and growing market of Sacramento and the surrounding parts of the Great Valley.

Although second-growth timber is unable to compete today with oldgrowth timber, the growing forest adds to the value of the property by making it more attractive, and the owner can obtain his fuel supply from thinnings which are of actual benefit to the forest. If preserved, moreover, the product of these second-growth stands, owned by the fruit growers of the county or immediately tributary to their operations, will not only provide income which promises on the basis of present information to be larger than that from alternative uses of such lands (pages 52 to 55 ), but, in view of the certainly depleted supply of virgin timber of that time, should also supply these fruit growers with box material more cheaply than it can be shipped in from elsewhere.

Program of Utilization.-On the basis of the facts relating to physical conditions and utilization and the income analysis presented on page 27 , it has been concluded that this area probably may continue with fresh-fruit production as the dominant use of the land. This will be possible, however, only if supplemented by the following:

1. Local industrialization in so far as local resources will permit. This should be the subject of a careful investigation by an industrial engineer.

2. Maintenance of the present forested area in forest to provide a future supply of lumber and box shook for local use.

3. Selection of one of the following alternatives of management of present areas of woodland and chaparral, according to the particular needs of a given farming operation, costs and effectiveness of clearing, and the degree of assurance of obtaining a good crop of grass without excessive soil erosion.

a) Protect the woodland and chaparral areas from broadcast burning, and continue to utilize these lands as at present for whatever grazing revenue is obtainable, just as is done on the National Forest land.

$b$ ) In individual cases where conditions warrant, completely clear the woodland and brush for the purpose of utilizing it for pasture. Broadcast burning will seldom accomplish this end.

Both of these alternatives are designed to keep the fire out of timber land. The first will in time result in seeding with coniferous trees and will ultimately develop a valuable timber stand; the second will improve pasture-carrying capacity.

4. Local production of a greater proportion of the products needed for sustenance of the farm population, by more extensive and intensive use of covercrops for domestic livestock feed and for soil protection, by a more complete and efficient use of the grassland of the area for 
grazing domestic animals, and by other possible improvements in farm management.

5. Continued vigilance in the reduction of public costs in town, county, and irrigation-district government and operation.

6. Organization of the agriculture of the community on the basis of present or reduced areas of orchard crops, present water supplies being ultimately supplemented by the completion of the small Weber Creek Reservoir.

7. Supply of late-season water to the Diamond Ridge Ditch from the surplus of the Weber Creek development.

8. Refinancing of the El Dorado Irrigation District in such a manner that repayments may vary with gross returns from the fruit industry. This should be the subject of special investigation.

\section{AREA II, POTENTIAL FARM AND/OR FOREST CROP}

The pertinent facts relating to the present utilization of area II, comprising 45,116 acres, are shown in figure 13 and in tables 14 and 15. The combined area of class 1 and class 2 lands is greater than in the case of the more highly developed lands of area I. A higher elevation offsets this advantage. Nearly 75 per cent of the area is covered with brush and timber, two-thirds of which is restocking with a good second growth of timber, only 2.6 per cent of the area is in orchard or vineyard crops, and a larger percentage of the lands is leased. Grazing carrying capacities are lower than for the grazing areas at lower elevations. The soils respond well to irrigation, but a large proportion of the lands is rolling, which handicap, combined with a heavy cost for clearing, places their economic use for farming under irrigation in the remote future.

On the portion of these lands situated on the Georgetown Ridge, water supplies, which are already available for some of the land, could easily be extended. The lands in the southcentral part of the county, however, could be supplied only at considerable cost. On an area of 15,000 acres in this classification, the average gross farm income in 1930, exclusive of supplies produced and consumed on the farm and exclusive of outside sources of income, has been estimated at $\$ 10,900$. Income from outside sources for the same year is estimated to have been $\$ 7,950$, bringing the total cash income to $\$ 18,900$. For the same year cash expenses are estimated to have been $\$ 21,200$. That year is reported as less favorable than those which had preceded it. However, the years that followed were much more severe. The significant fact shown by these figures is that under the conditions of 1930 , income from outside sources which was two-thirds that supplied by the farm, was not sufficient to meet cash expenses. An elaborate road system is being extended into the commu- 
nity. The state and county are, in reality, subsidizing this area and so far have enabled it to continue with some difficulty as a farming community. There are two schools in the community, one of them having difficulty in obtaining the five pupils necessary to keep it open. The other has been in session intermittently.

This, however, is not a true representation of the economic situation on the lands of this class on the Georgetown Ridge, where an upswing in mining activity, lumbering in the neighboring forest, 360 acres of irrigated land, and miscellaneous employment, maintain the population and therefore the school attendance at a fairly economical number, although at a cost greater than in the more densely populated sections.

This area, as in the case of area I, was practically all forested before the white man came. Likewise the production of timber crops is an alternative where other major uses are less profitable. As shown in table 17, the area available for growing timber, after excluding present grass and cultivated lands, is about half again as great as in area I, and the possible annual growth per acre of 400 board feet is approximately 38 per cent greater. The second-growth timber is also about sixty years old with nearly the same average stand and investment value per acre, but the area is more than twice as large. There is one significant difference, however, that should be mentioned. This is the less favorable location of area II for local utilization of its timber in the Placerville region. This timber when harvested must find, for the most part, outside rather than local markets, because it cannot compete in the latter with timber more immediately tributary to the local markets. The forested and potential forest lands not now cultivated nor in grass are similar in character to those of area $I$ and for them a similar utilization is proposed.

Program of Utilization.-The suggested program may be summarized as follows :

1. Maintenance of the present forest area as such, this to be accomplished by the exclusion of fires.

2. Exclusion of fires also from the woodland and chaparral areas that are interspersed with and adjoining the timbered areas.

3. On the Georgetown Ridge, maintenance of status quo with respect to land use and the further development of forest and mining resources. The historical values of this area are great and should be conserved.

4. On the Aukum and Fairplay lands of this classification:

a) Relieve the county and state from high-cost community services to isolated residents by assisting those now residing there to find more suitable locations and to establish themselves in the new locations.

b) Utilize the present grassland for extensive grazing, coördinated with other grazing areas at higher and lower elevations. 
c) Maintain the grasslands as free from brush as possible without resorting to methods that will jeopardize adjacent forest lands.

d) At such time as increasing demand for farm land warrants, develop a water supply at as reasonable cost as possible for probably 10 per cent of the total area.

e) Ultimate utilization may be for diversified fruit and livestock farming which recently and under conditions of 1930 has been unprofitable; or future economic conditions might necessitate the reversion of the entire area to forest.

\section{AREA III, LIVESTOCK PRODUCTION}

The significant facts concerning the lands of this classification and their utilization are indicated in tables 14 and 15, while figure 13 shows the extent and location of these lands in area III. There are two subdivisions of this area. In the one referred to as IIIA in tables 14 and 15, there are extensive areas of shallow soils and cleared grassland. Ninetythree per cent of the area is in farms, for the most part livestock farms. The greater part of these are used in producing beef, dairy products, or a combination of the two. A larger portion of the land is rented than in other parts of the county. This is an indication of a natural tendency towards consolidation. More of the lands of this area are used in conjunction with mountain range than is the case in any other part of the county. The small area of potential forest land is of low quality and is so scattered and fragmentary as to be of little value for growing timber.

The other lands of this economic classification, referred to as IIIв in table 13, have a larger percentage of class 1 land and a lower percentage of class 4 and 5 land than has subdivision IIIA. The topography is rougher, which fact, together with other physical differences, accounts for important differences in utilization. The total area in farms is smaller in comparison with the other subdivision of this classification. Areas of brush and timber are more extensive. A larger percentage of the farmers produce sheep, while a much smaller percentage of the area is used in connection with mountain range. Diversified farming is more prevalent. Under conditions of utilization in 1932 the state and county governments were spending approximately $\$ 10,400$ annually in this area for county roads and schools, while people in the area contributed only about $\$ 5,700$ in taxes.

Subdivision IIIв in contrast with IIIA contains a relatively large area, nearly 60 per cent of the total, capable of growing forests of ponderosa pine. The condition of this potential forest land in 1932 is illustrated in figure 14. The gentler slopes have in general been converted to grass or are cultivated, and the steeper slopes have reverted to dense woodland and chaparral containing fragmentary areas of thinly stocked second- 
growth pine. This oak and brush-covered land, embracing about 14,200 acres, or approximately 60 per cent of the potential forest area, is of little present value for anything.

That timber growing is possible on this land is indicated by table 17, which shows that this land, if well stocked with pine, can grow about 240 board feet per acre per year. Because, however, of the large investment

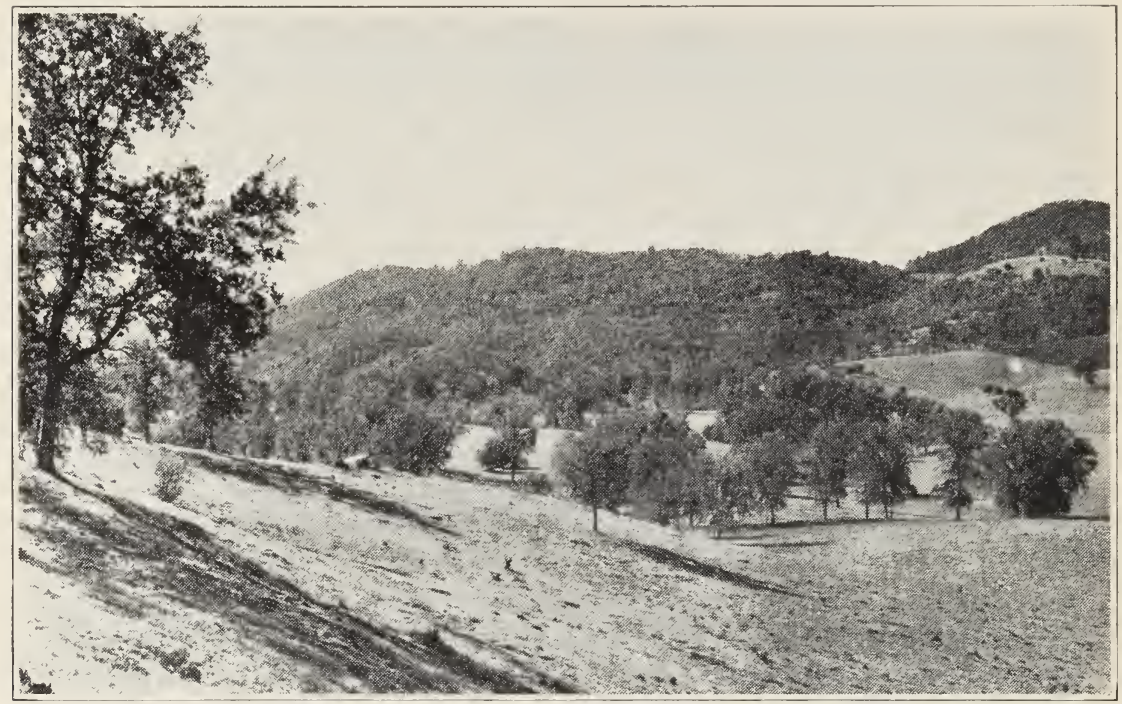

Fig. 14.-This area south of Shingle Springs is typical of the lands in the diversified livestock area that were once forested with ponderosa pine. The gentler slopes as here shown have in general been converted to grass or are cultivated, and the steeper slopes are so covered with dense chaparral and oak woodland as to be of little value for grazing.

involved in planting and the long time necessary for the trees to grow to saw-timber size, forest restoration, if undertaken, must probably be a public enterprise. In such an event the present owner should benefit by the sale of the land to the public agency. An alternative of more immediate value to the owner, if feasible, is the conversion of such land to a permanently better condition for grazing. However, as pointed out on page 55, neither tree-planting, on the one hand, nor, on the other hand, the large-scale removal of the present vegetation by burning or other clearing methods, is recommended until safe, effective, and cheap methods have been worked out experimentally. This, of course, does not apply to desirable small-scale clearings where the money outlay is not great, provided broadcast burning and other damaging use of fire is not employed.

State and national policy is involved in the decision between the above 
alternatives. The price at which the lands can be purchased will probably be the deciding factor. A combination of private and federal ownership may make possible the blocking out of federal forest lands among the privately owned lands.

Program of Utilization.-The suggested program may be summarized as follows :

1. In subdivision IIIA, which is the medium and large-scale livestock farming area of this general classification, further consolidation of holdings together with the relocation of certain farmsteads would introduce economies in the management of the livestock industry and in the administration of the county government. The remaining suggestions pertain to subdivision B of this classification.

2. Subdivision IIIB of this general economic classification includes mainly shallow soils, which are interspersed with about 15 to 20 per cent of the deeper and more fertile soils. The objective on such land should be a farm economy which will utilize the shallow grasslands for grazing and the deeper soils for irrigated or dry-farmed supplementary crops and which ultimately may utilize the timber resources of the lands having rougher topography.

3. Continue to use the deforested and nonforest lands now covered by woodland and chaparral for any forage value they may possess, but safeguard their capacity for a possibly more profitable future forest use by protecting them from broadcast burning or other damaging use of fire.

4. Postpone plans for large-scale removal of the present vegetation and conversion to grass until effective and at the same time cheaper methods have been developed experimentally.

5. A small amount of irrigation water on such a farm would have a high value, as in the case of area II. Any irrigation projects of the future should be designed to irrigate only a small portion of the total area. Such projects may be costly from the standpoint of the charge per acre irrigated, but more economical than those designed to serve too much land.

6. The problem of seasonal fluctuation in the feed supply of the area as a whole may be met by one or more of the following means:

a) Supplementary crops dry-farmed. These may include grain, hay, vetch, field peas, Egyptian corn, or other forage produced on tillable portions of the farm.

b) Production of alfalfa, clover, pasture, or other intensive crops under irrigation. Most of the soils of this particular area are not the best alfalfa soils; however, some alfalfa hay is being grown successfully.

c) The small enterprise may find it profitable to coöperate with others to make the use of mountain range economical. Previous attempts at 
such coöperation have not been successful here but have been so in some regions.

d) Purchase and sale of stock each year, pasturing them only during the grazing season.

$e$ ) Custom pasturage, renting the land during the grazing season to those grazing elsewhere during the winter and late summer.

f) Specialized farming with division of labor among different farming enterprises for the production of the feeds necessary for a unified community livestock specialization.

g) The consolidation of land holdings and livestock enterprises in order to obtain more economical producing units and more flexible systems of operation, including the economical use of distant pasture lands.

7. On those lands where supplementary feed crops can be grown, smallscale enterprises probably will be the rule, population will be more dense, and schools and roads more numerous. Local planning for economy can probably accomplish helpful results.

\section{AREA IV, FOREST CROP WITH RECREATION AND GRAZING}

This area, as shown in figure 13 , comprises practically 60 per cent of the western portion of the county which is outside of the National Forest boundary, and that portion of the National Forest lying below the 6,000 foot contour.

Because of the unsuitability of this land for cultivation, only 3 per cent of its area is now in fruit farms and the percentage actually under orchard or cultivation is very much smaller. Although extensively grazed, its value for that purpose is low. The population of the area has been steadily declining for many years. The schools that are still maintained are so small that their cost of operation per pupil is exorbitant. The time must be anticipated when they can no longer be maintained.

Area IV consists primarily of land which once bore coniferous forest. Sixty per cent of it still bears such forest, this being divided into virgin timber, 15 per cent, and second-growth, 45 per cent. This second-growth portion of the forest-crop classification area contains 11/4 billion out of the total $13 / 4$ billion feet of second-growth timber in the western division of El Dorado County. Of the remaining 40 per cent of the area, three-eighths is in woodland-chaparral or grass types. Of the 23 per cent covered by woodland and chaparral, nearly two-thirds is on land once forested, and of the 14 per cent of grassland more than four-fifths is so located.

The physical character of the lands, the natural vegetation, the economic position of the population, and the excessive cost of governmental services seem to indicate the desirability of devoting the area primarily to forest use. With primary dedication of this area to forest crop there 
will still be some forage production, probably, in the long run, greater than in the depleted condition observed in 1931, which can still be utilized by the tributary livestock producers. The building up of better forest conditions, with consequent greater attractiveness of the county, will also favor the development of recreation at suitable locations.

A small proportion of the lands of this classification has been included, not because of their forest-growth possibilities, but because, not being suitable for any agricultural use, they are adapted more to the type of management desirable for extensive areas of wild land than they are to private ownership and utilization. Other areas have been included which, except for their small size, would have been suited to some form of private agricultural utilization. If these small areas were continued as populated communities, their isolation within the more extensive areas of wild land would give rise to excessive costs of governmental service.

The generally high elevation of this area and its very small amount of cultivated or crop land, together with its 60 per cent of actual forest and 89 per cent of land once forest, and its high forest-productive capacity as shown by this investigation, make its forest-crop classification and use prospectively more profitable than the uses to which it is now being put.

Program of Ctilization.-These considerations lead to the following suggestions :

1. Utilization of the lands of this classification area primarily for forest production will secure a larger future revenue than any other present use.

2. The most profitable areas for first development of forest production will be those now bearing virgin or second-growth forest. Protection and improvement of these areas should be undertaken immediately. Realization of the potential returns will be increased and insured by putting these areas under technical forestry management at as early a date as possible.

3. Of the now deforested area, that in woodland and brush would be preferable for the first future reforestation. How to reforest such land at a more economical cost than has been possible in the past has still to be worked out, but there are promising possibilities awaiting investigation.

4. The complete exclusion of fire from both of the areas mentioned in recommendations 2 and 3 is the first requisite to the realization of their large future forest values.

5. Utilization of the grass areas for grazing revenue can profitably continue until their reforestation becomes desirable. 
6. Provision, as rapidly as may be feasible, of other locations and opportunities for the scattered resident population of this area is the best means of relieving them from the handicaps of their present isolation

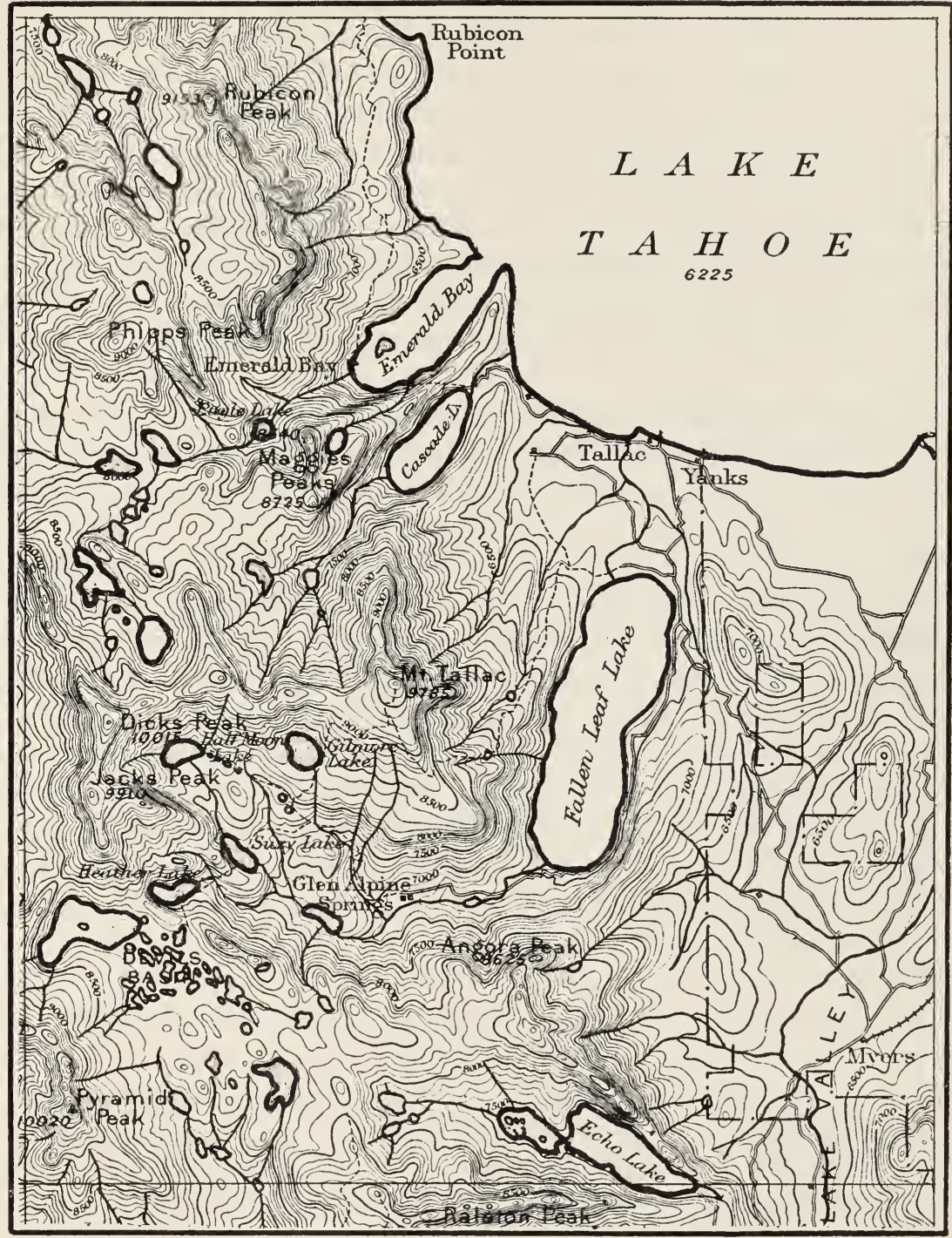

Fig. 15.-A portion of El Dorado County's playground. (Reproduced from the Pyramid Peak quadrangle of the U. S. Geological Survey.)

and of relieving the county of the excessively high cost of maintaining public services in such sparsely populated areas.

7. Reorganization of the rural-school system in such a way as to permit the discontinuance of small-attendance, high-cost districts. 


\section{AREA V, RECREATION WITH FOREST CROP AND GRAZING}

Area $\mathrm{V}$ embraces the highest lands of the county. ${ }^{30} \mathrm{~A}$ number of the mountain peaks exceed 9,000 feet. In this area many of the tributaries of the American River have their beginning. The ruggedness of the mountains, the number of streams and lakes, and the extensive wilderness area account for the growing popularity of the Lake Tahoe region as a center of recreation. A map of a portion of this area is shown in figure 15.

Program of Utilization.-The National Forest portion of this area has already been dedicated to recreational use by the Forest Service, and this dedication has been confirmed by the public, which has returned year after year in greater numbers. As a means of obtaining the greatest amount of benefit from recreational use, the following steps are suggested:

1. Careful subordination of every other use of the land to recreation as the dominant use. Uses which most often conflict with recreation or endanger scenic values upon which it rests are timber-cutting, grazing, mining, and injudicious road construction.

2. Joint planning of recreational development by resort associations, recreation clubs, business associations, and Forest Service. The soundest development of the entire section, and the prevention of monopoly, which would be prejudicial to the interest of the whole community, are essential to the highest success of this movement.

3. Coördination of the recreational development of this area with the general plan for the county for the complete realization of the county's unique recreational possibilities. These possibilities are not confined to area V. Recreation may well prove to be ultimately the central use of land around which will revolve the whole plan for the better economic prosperity of the county.

\section{THE MEANS BY WHICH LAND UTILIZATION MAY BE IMPROVED}

Of first importance in the execution of the proposals made for improving land utilization in the county is a recognition and reconciliation of the many conflicting interests which are sure to arise. Fairness in settling these differences will open the way to other important procedure.

Coöperation of educational and banking institutions in the reorganization of farms, the organization of local manufacturers for a soundly safeguarded program of local industrial development, the public acquisition of certain lands for the protection of public interests, and modifi-

30 The rapid growth of recreational activity in this section has already been described on page 64 . 
cation of state administrative policies and laws pertaining to the utilization and disposal of state-owned lands are among the steps that may be taken towards a realization of the objectives which have been stated.

Interests Which Conflict with a Program Involving Changes in Land Utilization.-Conflict between the immediate interests of the individual and those of the public arises from the fact that the practices in land use which promote the greatest profit to the individual may not always be those which result in good to the greatest number in the community. Moreover, the practices most immediately profitable to the individual may so tend to destroy or deplete the resource from which the profit is drawn that the individual as well as the community in the future will be impoverished. Business interests accustomed to receiving the trade arising from those residing in certain areas not suited to occupation are inclined to resist any attempt to remove the populations from those areas. In fact there is frequently a tendency to promote occupation of such areas far beyond their capacity to support a population. Thus, the interests of special groups may be in opposition to those of the larger population of which they are a part.

Another cause of conflict arises in connection with the financial support of governmental institutions. Changes in the ownership or utilization of land which threaten the impairment of taxable wealth are causes of concern, especially during times when public revenues are depleted as they were during the depression years of 1929 to 1933 . Large-scale delinquency, which takes land off the tax rolls, is strenuously resisted, more from the fear of declining public revenues than from the desire to relieve personal distress on the part of those losing their properties.

The reconciling of conflicting interests probably can be accomplished by an unprejudiced appraisal of the respective interests of different individuals and groups, by due compensation to those who sacrifice personal rights for public interests, by financial programs which will make possible the conversion of expected future returns from forests into present income, and by the providing of alternative sources of income where past sources are threatened by proposed changes.

Tax Delinquency as a Breakdown in Private-Land Ownership.Prior to 1929, reversion of land to the state because of tax delinquency was not of serious magnitude in California, but in that and the following years it rapidly increased. Examination of records of tax delinquency in California shows that in addition to the depression as a cause of tax delinquency, the same process is at work in many California counties, including El Dorado, which in a more advanced stage has already brought several eastern states to the danger of bankruptcy. This process is less spectacular than the depression but it is more per- 
manently harmful. It is the exhaustion of wealth by a kind of utilization of resources which tends to destroy them. Typical of this kind of utilization are the traditional lumbering practices which leave cut-over land without subsequent revenue-producing capacity, and the too frequent overuse of grazing lands which reduces them more gradually to a similar condition. It also includes the agricultural cultivation of land without measures for the maintenance of soil fertility and for the avoidance or prevention of soil loss by erosion.

In the foothill region the disastrous effects of exhaustion have been largely masked thus far by the exploitation of new resources as previous ones declined, and by state subsidies to the counties, chiefly for roads and schools. After early mining and agriculture came lumbering, then pear production, and last, recreation. Pear growing, to be sure, began with the gold miners, but its development as a major county industry is relatively recent. These activities in their larger phases are still too new to have suffered from resource exhaustion on any large seale in the county. But new resources cannot continue to be found indefinitely. In the absence of such new sources of wealth, as deterioration of land resources continues, owners fail to make a living and sell out for what they can get or forfeit their lands for taxes. New owners may buy the properties at reduced valuations, but in time they, too, succumb in a progressive liquidation process which involves cumulative human suffering, and its end is the impoverishment of the whole community. This process has already run its course to county bankruptey and economic and social decay over large areas of former forest land in some eastern states.

The wholesale tax reversion of lands, which finally marks the decline of sources of wealth, ushers in this financial breakdown of local government and decay of economic life in communities. Such tax reversion has been postponed in California counties; but there are signs of its nearer approach in some of the mountain and foothill regions. Without the maintenance of the natural sources of wealth, new farmers or industrial enterprises coming into an area may only supply new capital and labor for a time, without permanent prosperity for themselves or the community; and state subsidies may not contribute to permanent economic independence of the foothill counties. There is danger that both subsidies and the inflow of new capital and labor may become only continuous crutches bolstering an intrinsically uneconomic system. They may be real aids to the restoration of economic well-being if the land uses of the county are ones which put to work all the mutually compatible resources of each area, and are so conducted as to maintain the productivity of each resource utilized. To find out how best to apply means of salvaging private-land ownership, or of putting the land into 
public ownership where that appears necessary, is an object worth serious study.

Taking Depleted Land Out of Circulation.-When the productive capacity of land has been seriously depleted, unless another type of soilbuilding management can be substituted for the practices which have caused that depletion, it should be retired for recuperation by letting it lie fallow, with whatever measures may be needed to prevent further deterioration and to hasten the restoration of the land to productivity.

In the case of grain land this fallowing is a common practice and does not involve relinquishment of ownership unless the deterioration is extreme. In the case of grazing land a similar result may be accomplished by a constructive grazing management. But since the signs of range deterioration as well as the requirements of such management are often less well understood, the process often goes on for a long time and to an extent which makes adequate remedy more difficult for the private owner. The forest crop, by reason of its long-time nature, is the most difficult of all to rehabilitate once the forest is badly abused and the productivity of the land is depleted. During the interval until productivity can be restored and a new crop matured, the owner can look for income return only from constructive grazing, recreation, or other limited extraneous uses, although the increase in volume and value of the growing timber stand should make such land well worth holding. This value can only be realized, however, with well conceived and well executed plans of recuperative management.

In all these cases the owner may be unable to carry land through an interim of reduced or absent income return. When he has to relinquish ownership, it is shortsighted, in the case, for example, of tax reversion, for the county and the state to seek to pass on to new private ownership land which can only repeat the same cycle of ownership distress and liquidation. Government, more easily at least than the individual, can carry land through the interim until returning production, because of the lesser burden to it of the time factor, among other things.

Public Acquisition of Land.- - It has been noted earlier that the realization of the management of forest and other wild lands for many uses may require public regulation on private lands to prevent unfair shirking of obligations by a minority, and that in cases of exceptional conflict between uses the management may have to be administered by the government.

Public acquisition, by the state or the United States government, of as great a proportion as possible of land in classification areas IV and $\mathrm{V}$, adapted primarily to forest crop and recreational use, will probably result in the greatest amount of benefit to the public as well as to local 
interests. The ownership of these lands by the public will preserve the public services of such lands and secure their maximum returns through utilization of all sources of revenue. The unstable condition of the lumbering industries in recent years, the length of time required to grow a timber crop and the probable future importance of that crop to the nation, the public interest in scenic values and recreational uses of wild lands, the statewide importance of controlling erosion, stabilizing the water resources, improving navigation of the lower courses of the great rivers by regulating stream flow and debris in the upper courses, and of preventing repetition of the disastrous economic and social results of past attempts at land settlement in areas such as IV and V, justify the decision that the lands in these areas are best suited to management by the public.

State acquisition of land for forest purposes in California has been difficult, if not impossible, because there has been no fund from which direct purchases of land for such purposes could be made, and both laws and administrative policies have required that lands which revert to the state because of tax delinquency must be handled on the basis of resale to private ownership as quickly as possible.

Those states where reversion has developed to a much more acute stage than in California have found the resale of lands that have reverted, without regard for their adaptation to private utilization, so disastrous that they have been forced to abandon the practice. Tax reversion offers an opportunity, which should not be sacrificed, for deliberate consideration of the most desirable future uses of the land and for the molding of laws and policies in such a manner that constructive disposition and utilization of such lands may be made possible.

State laws could be modified to make possible the holding by the state of lands which have reverted until their best utilization and disposal are determined. Their incorporation with other state lands, already publicly owned or purchased as needed, would facilitate the inauguration of state forests on lands suitable for that purpose. When federal ownership appears to be the most desirable course, their exchange with or transfer to the federal government could be arranged.

Summarized briefly, public ownership of forest-crop lands suitable to such acquirement should go far to assure a permanent supply of timber for local industries and for local and state needs, more efficient management and maintenance of the grazing resources, the fostering of increased development of recreational resources, important reductions in cost and increase in efficiency of local government, and the prevention of misuse and waste now widespread throughout the area.

Under existing conditions the more promising alternative is doubtless 
the acquirement of land suited primarily for forest growth by the federal government. The immediate proximity of the National Forest, with the authority to acquire suitable adjacent lands conferred by the Raker Act, as has already been suggested, would simplify the transfer of such lands to that branch of the federal government. The United State Forest Service administrative units now in existence will also provide the organization required.

If the suggestions made above for public acquisition of rather extensive areas within El Dorado County are carried out, provision should be available for reimbursement to the county for funds diverted from the county treasury because of the taking away of the assessed valuation represented by these lands. In the case of federal acquisition, this provision already exists and such losses are on the average more than made up to the counties by the law requiring the return to the state for the county treasuries of an amount representing 25 per cent of the gross receipts of the national forests, with a further return to the counties of 10 per cent of the gross receipts for road and trail construction by the Forest Service. This is in addition to the greater federal appropriations directly for road construction in coöperation with the state, under which such major projects as the Lincoln Highway through El Dorado County have been built. Besides these contributions from the national forests, there are advantages to be gained by local communities in the free use of timber for farm or individual construction, the free grazing of milk cows and other domestic animals, and other more general benefits.

The above statement that the returns from National Forest ownership and management of such lands will at least equal those to be expected from taxation in private ownership is supported by a study $y^{31}$ of this whole situation, which was made for the entire state on the basis of the average figures for the five years from 1923 to 1927. This study showed that, considering all the California counties containing national forest land, these repayments from the federal government on account of national forest lands in lieu of taxes amounted to 30 per cent more than the tax return which could reasonably be expected under private ownership of these lands - which include large areas from which no tax return would be realized because they are too rocky or inaccessible or otherwise worthless to be profitable for private owners to acquire and pay taxes upon.

Some counties containing national forest land, but where timber sale and other revenue-producing activities have been small, have not thus far shared in federal returns in as large proportion as those counties

31 Show, S. B. How the national forests of California benefit the state. U. S. Dept. of Agr. Misc. Pub. No. 82:1-8. 1930. 
having larger federal business. With the increasing development of the whole National Forest area, however, these returns to the counties will increase. The 25 per cent item for the entire state, upon which the 30 per cent excess of such returns over probable taxation returns was computed, averaged $\$ 297,554$ for the five-year period $1923-1927$, while as shortly after the close of the study period as 1928 , the same item had risen to $\$ 406,877$.

The whole matter of public acquisition, of course, rests upon the arrangements which can be made between individual owners and the government. Certain aspects of such acquisition present difficult questions. The large numbers of small mining properties probably will make it impracticable for the federal government to acquire all lands of this classification. This is not important, however, if the greater part of the area is placed under federal control. In addition, the small scattered farms throughout this classification area are usually on land which is of a higher quality than the larger part of such lands. These farms will be the deciding factor in answering the question whether the areas so classified must be continued as sparsely populated communities with abnormally high costs of county governmental services, or can be devoted to a manifold utilization which will not require population. Existing permissible federal payments per acre do not provide for adequate remuneration to owners of the occasional tracts whose values exceed those of surrounding lands but which should be included for the completion of the general plan. Some provision must apparently be made in existing federal laws for adequate compensation to the owners of such lands, if they are to be included in blocking out large contiguous tracts of wild lands.

Relation of Taxation Policies to Land Ltilization.-It has been shown how, under existing laws, residence in isolated areas is subsidized by contributions by the state for education and highways, and that these iaws make it possible for much greater expenditures of public funds to be made in an area than can be provided by the taxable productivity of that area. It is especially important to examine further recent legislation previously referred to which has increased the amount of state contribution of funds for expenditure by the respective counties.

These provisions can be made of great value to the foothill counties. However, if these counties are to receive permanent advantages from the law, it is of utmost importance to follow up the constitutional amendment increasing subsidies for schools with legislation which will prevent the otherwise inevitable extension of the marginal zone of highcost county services, such as schools and roads, which is characteristic of the "fringe" of settlement in the foothill areas. This can be done by 
zoning against the establishment of schools and the extension of roads in areas unsuited to settlement. Decision as to unsuitability can be reached by an economic classification of the land similar to that here proposed for El Dorado County. Children of temporary mining or logging camps can be provided schooling where possible in nearby permanent communities or by special provision for temporary schools.

Increases in county revenue from local taxation of utilities, from increased state contribution to school support, and from the reclassification of certain county roads as state highways, should make possible reduced taxes on certain wild lands which are incapable of carrying the tax burden now upon them. Laws providing for such changes in methods of taxation have been enacted. They will result in good or harm according to the wisdom with which regional planning and zoning is used as a means of preventing utilization of these lands in an uneconomical manner. Reduction of taxes is highly desirable if utilization is restricted by zoning. Reduction of taxes in any one part of the county has been impossible in the past, however, because its only result would have been to shift the load in other parts of the county to lands equally as incapable of carrying it.

An amendment to the State Constitution, Article 13, Section 123/4, adopted by popular vote, November, 1926, was intended as a means of encouraging the growth of timber. However, it merely exempts from taxation "immature forest trees which have been planted upon lands not previously bearing merchantable timber, or planted or of natural growth upon lands from which the merchantable original growth timber stand to the extent of 70 per cent of all trees over sixteen inches in diameter has been removed." There is much land now in brush which is assessed at $\$ 6$ an acre and extensive tracts of cut-over land assessed at $\$ 3$. At recent tax rates these lands would pay a tax of 17 and of $8 \frac{1}{2}$ cents an acre, respectively. Even if the growing timber on these lands is entirely exempt from taxation these annual payments would amount, at 4 per cent interest compounded annually, to $\$ 42$ and $\$ 21$, respectively, in sixty years. Such cases illustrate some of the difficulties in the tax situation. Forest-land taxation needs special treatment because of the long period during which the annual growth must accumulate before harvesting. On the other hand, some means must be provided for maintaining necessary county revenues in the interim of any deferment of timber taxation. The very difficult problems of forest and wild-land taxation are being intensively studied in the United States. Improved laws are to be hoped for within a few years.

Depopulation of Areas Adapted to Frost, Recreation, and Extensive Grazing.-Public acquisition of land by purchase will tend to reduce 
the population in areas zoned for such acquisition. The policy just proposed for preventing the establishment of schools in areas unsuited to settlement would have a similar effect. There are additional means, however, by which the objectives of zoning such land can be accomplished without hardship or injustice. Zoning here, as it often does in cities, may accomplish the desired result gradually by discouraging the establishment of undesired uses of land rather than by the immediate removal of such existing uses. To carry out the entire program of zoning will require some years. In the meantime the residents in certain areas will have moved away either because of the difficulties of obtaining a living or because the purposes for which they came have ceased to attract them. If the stream of incoming population could be cut off, the problem of an uneconomic population would ultimately be solved. In other areas meager returns, tax delinquency, and mortgage indebtedness are already doing their part in discouraging attempts at making a living under such severe conditions. In such cases the process undoubtedly could be hastened and made less disastrous than if the natural economic adjustment is allowed to take its course. In still other instances an opportunity to live elsewhere, in much the same kind of environment, but in a situation where it will be more economical for the individual and less costly for the county and state governments, is all that will be necessary to induce the abandonment of this last frontier which lacks the compensating qualities of the frontier of a half century ago.

Farm Reorganization.-To carry out the proposed changes in farm organization, more intensified assistance to farmers on problems of farm management can be helpful. In most cases, however, the financial problem will be the greatest obstacle. Further investigation of possible improvements in farm organization combined with inquiry into individual capital requirements for the proposed changes and a determination of security values of the farms to be improved should constitute the basis for enlisting the coöperation of credit agencies. It may be desirable to select some area for intensive work along the lines of these suggestions, for the purpose of working out methods for and further possibilities of such reorganization. A definite program in certain areas for increasing the degree of support of farm families from products of their own farms may require an educational drive.

Refinancing the El Dorado Irrigation District and the Reëstablishment of Agricultural Credit.-It has been indicated (page 75) that the whole credit structure within the irrigation-district boundaries is dependent upon the ability of the land owners to meet the district obligation. The joint action of credit agencies, bondholders, and water users will be needed to work out a revised schedule of irrigation-district bond 
retirement and interest payment, which can be met by the water users without impairment of farm operation. Such coöperation is necessary for the reëstablishment of agricultural credit within the district.

A Suggestion for Conservative Fostering of Industrial Development. -The specific steps that are necessary to bring about a desirable increase in industrial activity in the county may require more preliminary organization work than will be necessary with respect to some of the other steps in carrying out the land-utilization program. For administering any public lands acquired by the government, for example, the United States Forest Service already has an office in Placerville. To carry out the proposal in connection with improved farm organization, the Agricultural Extension Service of the University is represented by a local farm advisor, also located in Placerville. Local banking institutions have indicated their willingness to assist in any way possible to supplement the efforts of the farm advisor in bringing about desired improvements. But who shall assume the responsibility of fostering a healthful growth of local industry?

It seems that this responsibility will fall back upon the leadership of the community. Unwise promotion and its possibly disastrous effects may be avoided by careful study of various possible industries and their relation to the whole plan of land utilization and economic development of the community. It would seem that a local association of business interests might accomplish much by financing the services of a competent industrial engineer to investigate, coördinate, and plan such development.

A Local Land-Utilization Committee.-A local land-utilization committee seems to be the logical first step. Leadership within the community will accomplish more towards the development and carrying out of a plan than would result from a complete dependence upon outside help. Coöperation with such a committee by appropriate state and federal representatives undoubtedly could be of assistance and in all probability would be extended as far as possible.

Such a committee could be a small one but of sufficient size to represent the principal local interests. Its primary functions would be to study the whole problem, initiate and coördinate the compilation of information concerning the different phases of the program; to stimulate existing or newly organized groups to perfect and work out the various details which have been sketched here only in their major aspects; to reconcile conflicting interests; to foster an intimate relation with public and other agencies from which assistance and information can be obtained; and to promote the adoption of such legislation and administrative policies as will be required. 
Wholehearted interest in the future of the county, knowledge of true conditions, a plan for meeting the most important problems, and a determination to succeed should go far to accomplish the objectives sought.

\section{A PROPOSED INITIAL STEP}

In order to provide a demonstration and test of the suggestions made for the utilization of El Dorado County land, an initial step is proposed as a direct means of accomplishing at an early date some of the objectives. The proposal includes the reorganization on a sustained yield basis and refinaneing of the lumber mill situated at Diamond Springs, referred to on page 56, acquisition by the federal government of a controling portion of the privately owned virgin and cut-over timber and submarginal farm lands tributary to this mill; the planning and development of Diamond Springs as a rural industrial area; the rehabilitation of the Diamond Ridge Water Company, previously referred to on page 33; and the establishment of a permanent residential community, by the aid of long-term credit, in which the employees of the manufacturing industries in the proposed Diamond Springs industrial area would be enabled to construct homes on small allotments with facilities for garden, family orchard, and domestic livestock. The agriculture would be very limited and noncommercial.

This initial program would turn a decadent community into a permanent and more prosperous one, reduce government costs, and increase county revenues. It would translate deferred future returns from forest conservations into present values and would combine and coördinate the returns from agriculture, forest, minerals, and other resources into a means of livelihood for the residents of the county. 


\section{ACKNOWLEDGMENTS}

The coördination of the work of different specialists is fundamental to research in land utilization and economic planning. The information presented in this bulletin and the conclusions reached are by no means the work of the authors alone. The physical classification of the land has been carried out in coöperation with the Division of Soil Technology of the College of Agriculture. The crop survey, which formed the basis for certain phases of the analysis was made by W. W. Weir and R. E. Storie, of the Division of Soil Technology. R. B. Tootell assisted in carrying out the field surveys on the Georgetown Ridge, and in the analysis of the results. Ivan W. Lilley, Farm Advisor in El Dorado County, has made many practical suggestions of importance in formulating and carrying out the general plan. Associate Professor A. W. Sampson, Plant Ecologist in the Agricultural Experiment Station of the University, has given valuable advice and coöperation in the interpretation of range conditions and other problems of range management and fire control. In considering the outlook for pear production the published and unpublished records of Dr. S. W. Shear have been drawn upon. The authors have also had the coöperation and advice of E. I. Kotok, Director of the California Forest and Range Experiment Station of the United States Forest Service and Consulting Forester in the California Agricultural Experiment Station, Professor Walter Mulford, head of the Division of Forestry in the University and Forest Economist on the Giannini Foundation, Professor C. F. Shaw, head of the Division of Soil Technology in the University, and Professor H. R. Tolley, Director of the Giannini Foundation of Agricultural Economics. The Placerville Fruit Growers' Association, the various fruit companies, local farmers, and many others have contributed useful material used as a basis for the investigation. 
